$1-1-1978$

\title{
Minimum resource requirements for a 100 beef cow-calf enterprise -Leading Creek, Randolph County, West Virginia
}

David D. Hughes

Paul E. Nesselroad

Follow this and additional works at: https://researchrepository.wvu.edu/ wv_agricultural_and_forestry_experiment_station_bulletins

\section{Digital Commons Citation}

Hughes, David D. and Nesselroad, Paul E., "Minimum resource requirements for a 100 beef cow-calf enterprise -Leading Creek, Randolph County, West Virginia" (1978). West Virginia Agricultural and Forestry Experiment Station Bulletins. 663.

https://researchrepository.wvu.edu/wv_agricultural_and_forestry_experiment_station_bulletins/563 @ WVU. It has been accepted for inclusion in West Virginia Agricultural and Forestry Experiment Station Bulletins by an authorized administrator of The Research Repository @ WVU. For more information, please contact ian.harmon@mail.wvu.edu. 

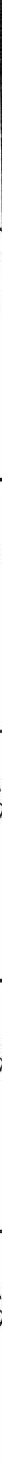

\section{Uinimum Resource Requirements bra 100 Beef Cow-Calf \\ Enterprise-Leading Creek, Randolph County, West Virginia}
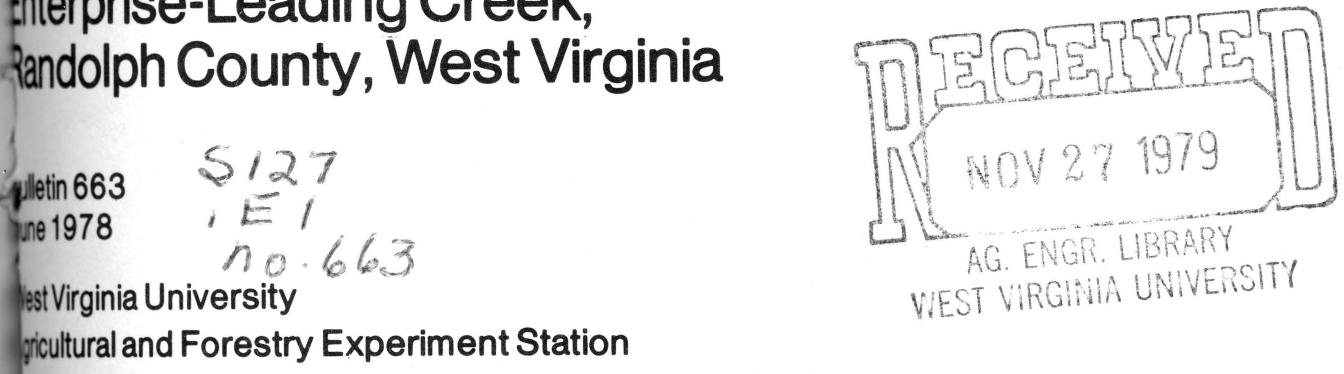


\title{
Authors
}

David D. Hughes was a graduate assistant in the Division of Resource Management, West Virginia University College of Agriculture and Forestry, and Paul E. Nesselroad is Agricultural Economist, West Virginia University Agricultural and Forestry Experiment Station.

\begin{abstract}
Farmers often express the desire to know the minimum resource requirements, and the cost of those requirements, to begin, expand, or minimize the cost of a beef cow-calf operation. The major objective of this study was to determine the minimum resource requirements, at minimum cost, for a 100 beef cow-calf enterprise. These minimum requirements were determined when considering the feeding alternatives of (1) hay and pasture only, (2) silage and pasture only, or (3) a combination of silage, hay, and pasture. The minimum resource requirements were determined using present yields of crops and input prices and also using estimated future (1985) crop yields and input prices. A conventional linear programming model was employed in the analysis. The model was developed so as to permit the model to be applied to other areas of the State with necessary adjustments.

The study area included five farms in the Allegheny Highlands Project located in the Elkins, West Virginia area. Data from this area were used to determine land and soil characteristics, climatic conditions, and most crop yield levels.

Budgets were developed where necessary to estimate the coefficients (costs, yields, input requirements, etc.) needed to utilize the linear programming model. Costs were determined to show the beginning, initial cost of the beef enterprise utilizing the feeding system which would have the least cost for both present and future conditions. Minimum resource requirements, at minimum cost, were also determined for the other alternative feeding systems on an individual basis. No attempt was made to show a return to the enterprises.

The analysis indicated that in 1975 the silage- and pasture-only feeding system had the least cost $(\$ 526,664.24)$ when using present crop yields and input prices. The silage, hay, and pasture system had an intermediate cost $(\$ 554,072.47)$, while the hay- and pasture-only system had the highest cost $(\$ 573,388.33)$.

Using estimated future data, the analysis indicated that in 1985 the silageand pasture-only system still would have the lowest cost $(\$ 689,386.98)$. The hay- and pasture-only system would have the intermediate cost $(\$ 721,867.83)$ and the combination system would have the highest cost $(\$ 722,181.49)$.
\end{abstract}

West Virginia University

Agricultural and Forestry Experiment Station

College of Agriculture and Forestry

Dale W. Zinn, Director

Morgantown 
Purpose of the Study $\ldots \ldots \ldots \ldots \ldots \ldots \ldots \ldots \ldots \ldots$

Study Area $\ldots \ldots \ldots \ldots \ldots \ldots \ldots \ldots \ldots \ldots \ldots \ldots \ldots$

Land Use Capability Classes ............... 4

Elevation and Climate................... 4

Procedure.$\ldots \ldots \ldots \ldots \ldots \ldots \ldots \ldots \ldots \ldots \ldots \ldots$

Data Sources ......................... 5

Analysis Procedure $\ldots \ldots \ldots \ldots \ldots \ldots \ldots \ldots \ldots$

Presentation of Programming Analysis ............ 9

Minimum Cost Solution: Silage and Pasture Only Feeding

System-Present Crop Yields and Input Prices ........ 11

Silage, Hay and Pasture Feeding System-Present Crop

Yields and Input Prices .................... 16

Hay- and Pasture-Only Feeding System-Present Crop Yields

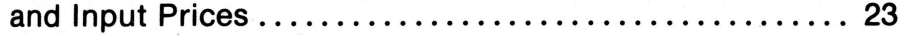

Minimum Cost of Resource Requirements for $1985 \ldots . .28$

Minimum Cost Solution: Silage- and Pasture-Only Feeding System-Future (1985) Crop Yields and Input Prices.... 28

Hay- and Pasture-Only Feeding System-Future Crop Yields and Input Prices .......................... 34

Silage, Hay and Pasture Feeding System-Future Crop Yields and Input Prices .......................... 44

Resume of Programming Results $\ldots \ldots \ldots \ldots \ldots \ldots \ldots 46$

Effect of Land Costs on the Total Investment Requirement46 
Summary........................... 48

Bibliography $\ldots \ldots \ldots \ldots \ldots \ldots \ldots \ldots \ldots \ldots \ldots \ldots \ldots$

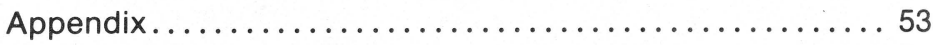




\title{
Minimum Resource Requirements for a 100 Beef Cow-Calf Enterprise- Leading Creek, Randolph County, West Virginia
}

\author{
David D. Hughes and Paul E. Nesselroad
}

The production of beef cattle is an important enterprise in West Virginia. Sales of forage-consuming livestock and livestock products represent about 40 percent of the value of all farm products sold. ${ }^{1}$ Not only is livestock an important source of income to farmers of the State, but it is the major source of income in some counties.

The rough terrain of West Virginia is more suitable for livestock grazing and forage production than for other agricultural uses. A large proportion of the land is used to provide other forage, such as corn silage, to supplement these crops, if necessary, for beef cattle production. Of the total land area of the State, 12 percent is pasture and 7 percent is in cropland. Sixty-eight percent of the land area consists of forest. ${ }^{2}$ Beef production requires pasture and other forage, and land suitable for pasture production is dominant over other types of land, except woodland, in most areas of West Virginia.

\section{PURPOSE OF THE STUDY}

Beginning farmers, farmers wishing to expand their operations, or farmers desiring to minimize cost in their operations have often expressed the need for information on the minimum resources required to begin, expand, or minimize. the cost of a beef cow-calf operation. The majority of past studies have been on the minimum resources needed to produce a particular income level for various agricultural enterprises. Few, if any, studies have been made on the resource levels needed to operate a herd of specified size. Also, farmers often desire to know resource requirements for the future after considering possible crop yield and price increases which may occur in coming years. For these reasons, this study will determine the minimum resource requirements for a 100 beef cow-calf enterprise. These requirements were determined first by using present crop yields and present prices of inputs under moderately intensive management, and then adjusted by using projected future yields and projected future prices.

USDA, State Farm Income Statistics, Economic Research Service, Supplement to Statistical Bulletin No. 547 (Washington, D.C.: U.S. Government Printing Office, September, 1975), Table 09, p. 81.

${ }^{2}$ West Virginia Soil and Water Conservation Needs Inventory, U.S. Department of Agriculture, State of West Virginia (Morgantown: Soil Conservation Service, 1970), p. 2. 
The overall objective of this study was to determine, through the development of a linear programming model, the minimum resource requirements, at minimum cost, for a 100 beef cow-calf enterprise in the Leading Creek area, Randolph County, West Virginia.

\section{STUDY AREA}

The five farms used in this study are located in the area of Leading Creek, north of Elkins, in the Allegheny Highlands of West Virginia. The topography of the area ranges from gently sloping bottomlands to rather steep uplands. The soils and climate are typical of the central beef-producing areas of the State. The soils are capable, with proper management, of producing those crops necessary for beef production. The elevation and climate of the area provide an environment conducive to beef production.

Each of the five farms has more than one soil type. Although these soils are similar, they do show differences in use capabilities and fertility levels. The following soils are typical of the area: Philo, Atkins, Alluvial land, Tygart, Ernest, Berks-Weikert, Brinkerton, Cookport, Monongahela, Gilpin, Berks and Charles. $^{3}$

\section{Land Use Capability Classes}

Land is separated into different classes according to its use capability (soil, type, slope, erosion ... .). The land in the five-farm area ranges from Class I through Class VII (no Class V). The amount of Class I land is very small, whereas Class VII land is abundant. For an explanation of the description and uses of each land class refer to Cooperative Extension Circular 406R. ${ }^{4}$

\section{Elevation and Climate}

Elevation and climate have an effect on agriculture, mainly in determining the length of the growing season. Length of growing season can often determine what type of agriculture is best suited to a particular area. The elevation ranges from 1,900 to 2,300 feet $^{5}$ in the five-farm study area. The climate in the five-farm area allows for an environment well-suited to beef cattle production. The growing season is long enough for production of most of the crops necessary for beef production.

January is the coldest month and July the warmest in West Virginia. The following are climatic characteristics of the area ${ }^{6}$ : The January mean minimum temperature is $20^{\circ} \mathrm{F}$ and the mean maximum is $40^{\circ} \mathrm{F}$. The mean minimum and maximum temperatures in July are $56^{\circ} \mathrm{F}$ and $82^{\circ} \mathrm{F}$. The average number of days annually with temperature $32^{\circ} \mathrm{F}$ or below is 150 , and 10 days annually average $90^{\circ} \mathrm{F}$ or above. The average date of last occurrence of $32^{\circ} \mathrm{F}$ or lower in

\footnotetext{
${ }^{3}$ For a description of most of these soils see U.S. Department of Agriculture, Soil Conservation Service and Forest Service, in cooperation with West Virginia Agricultural Experiment Station, Soil Survey Tucker County Part of Northern Randolph County (Morgantown: Soil Conservation Service, March, 1967), pp. 5-27.

${ }^{4}$ George Sharpe, Land Judging - Learning to Know Your Soil, West Virginia University Cooperative Extension Service Circular 406 R (Morgantown: West Virginia University), undated.

${ }^{5}$ Determined from maps prepared by the U.S. Geological Survey, Washington, D.C., 1969.

${ }^{6}$ Roy E. Trent, Robert D. Weedfall, and W. H. Dickerson, West Virginia Climate in Relation to Weather Sensitive Industry, West Virginia University Agricultural Experiment Station Bulletin 591T (Morgantown: West Virginia University, 1970), pp. 6-18.
} 
the spring is May 10 , and the average date of first occurrence of $32^{\circ} \mathrm{F}$ or lower in the fall is September 30. Average length of the growing season in the area (frost-free) is $140-150$ days.

The mean annual precipitation, based on the period 1931-1960, is 48 inches and rainfall in the mean growing season (May-September), based on the same period, is 24 inches, with the mean July rainfall (a month critical to pasture) of 5 inches. The mean annual snowfall, 1931-1960, is 100 inches.

\section{PROCEDURE}

\section{Data Sources}

Five study farms of the Allegheny Highlands Project located in the Leading Creek area in Randolph County, West Virginia, were used to determine a distribution of the land by use (cropland, pastureland, woodland, or farmstead) and land capability class (soil type, slope, erosion...). ${ }^{7}$ The price of land used in this study was $\$ 547.45$ per acre. This figure was computed from the average sale value of land in Randolph County for the tax year 1968-698 and adjusted to the 1976 value using an index to reflect the increase in sale value for West Virginia land sales.

The determination of the cost per acre for growing the necessary crops was made by compiling crop enterprise budgets. ${ }^{9}$ The information needed to develop these budgets, such as field operations and hour requirements, was obtained from Institutional Farm Planning Guides ${ }^{10}$ and Virginia Polytechnic Institute Extension Service crop guide data. ${ }^{11}$ The field operations necessary for the production of each crop and the materials and seeds needed were taken from the planning guides. Agricultural Prices, ${ }^{12}$ regularly published U.S. Department of Agriculture price information bulletins, were used as a source of material and seed prices in addition to up-to-date prices obtained from a local retail feed, seed, and farm supplies dealer. The costs, hours of equipment use, and labor requirements for each field operation were taken from the VPI Extension publication. Crop yields: corn silage, rye silage, various hays, and pasture were based on data collected by personnel associated with the West Virginia Agricultural Experiment Station for the Randolph County area. Crop yields were obtained in tons or pounds while livestock feed requirements were determined in pounds of total digestible nutrients (T.D.N.) and crude protein (C.P.). Crop yields were converted to yields after losses due to harvesting,

'See Appendix Table 1 for distribution of land by land classes.

${ }^{8}$ Based on data from a manuscript (in print) by Dale Colyer and Mary Templeton, Land Transfers, Values and Assessments for West Virginia 1968-69, West Virginia Agricultural Experiment Station (Morgantown: West Virginia University) Appendix Table IX.

${ }^{9}$ The crop enterprise budgets may be found in Appendix Tables 2 through 13.

${ }^{10} \mathrm{College}$ of Agriculture and Forestry, "A Plan for Integrating the Operations of West Virginia's Institutional Farms," West Virginia University College of Agriculture and Forestry (Morgantown: West Virginia University, October, 1975).

"Virginia Polytechnic Institute and State University, Costs and Returns Guide for Crops in Virginia, Extension Division Publication 607 (Blacksburg: Virginia Polytechnic Institute and State University, revised June, 1974).

${ }^{12}$ U.S. Department of Agriculture. Agricultural Prices, Statistical Reporting Service, Crop Reporting Board (Washington, D.C.: U.S. Department of Agriculture, January, 1975 through January, 1976). 
storing and feeding. ${ }^{13}$ A Soil Conservation Technical Guide ${ }^{14}$ was utilized to adjust crop yields due to land classes and soil types for the area.

The intensity of management (fertilization and liming rates for the most part) affects the yields which are obtainable from most crops. Future crop yields were estimated and the increases in fertilization and liming rates to obtain these yields were made. The possibility of the development in the future of higher-yielding seed hybrids was not considered.

The various machinery required for crop production ${ }^{15}$ was determined. Prices used for determining the purchase cost of this machinery were obtained from the USDA Agricultural Prices ${ }^{16}$ and through contact with local farm machinery dealers.

The composition of the 100 beef cow herd is as follows:

\title{
Kind of Cattle
}

Number of Head

Breeding females: ${ }^{\mathrm{a}}$

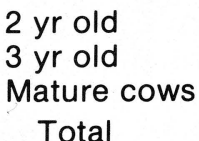

Total

Breeding bulls

Replacement bull

Annual calf crop: ${ }^{\text {b }}$

Steer calves marketed

Heifer calves marketed $\quad 30$

Heifers for replacement $\quad 16$

Calves not born or lost ${ }^{c}$

Total

\begin{abstract}
${ }^{a}$ Replacement heifers are bred near 15 months of age to calve at 24 months of age. Two of the 2-year-old heifers would be culled between 2 and 3 years of age.

${ }^{\mathrm{b}}$ Average market weight of calves sold was estimated to be 460 pounds.

${ }^{c}$ Cows not dropping calves, calves born dead, or calf deaths before market weight were estimated to be 8 percent.
\end{abstract}

The development of a livestock budget ${ }^{17}$ cannot be attributed to any one source. Several publications and unpublished research results were used; however, the two principal publications used were written by Barr ${ }^{18}$ and

${ }^{13}$ See Appendix Table 14 for T.D.N. and crude protein percentages.

${ }^{14}$ Soil Conservation Service, "Estimated Average Acre Yield of Principal Crops," West Virginia Technical Guide LRA-126, Section II-D (Morgantown: Soil Conservation Service, February, 1970).

${ }^{15}$ Machinery complements for the alternative livestock feeding systems may be found in Appendix 15.

${ }^{16}$ U.S. Department of Agriculture, Agricultural Prices, op. cit.

${ }^{17}$ See Appendix Table 16 for livestock budget.

${ }^{18} \mathrm{Alfred}$ L. Barr, George E. Toben, and Charles C. Wilson, Jr., Resources, Production, and Income on Eastern West Virginia Beef Cattle Farms, West Virginia University Agricultural Experiment Station Bulletin 546 (Morgantown: West Virginia University, 1967), Table 28, p. 37. 
Layton. ${ }^{19}$ Estimates and advice of WVU Extension personnel also were used. Labor requirements for livestock were taken from Pennsylvania State University data ${ }^{20}$ and adjusted to compensate for differences in season selection and in labor requirements between the alternative feeding systems. The livestock equipment value from Layton ${ }^{21}$ also was adjusted to match each feeding system.

The annual T.D.N. and crude protein needs for the 100 beef cow herd in pounds are as follows:

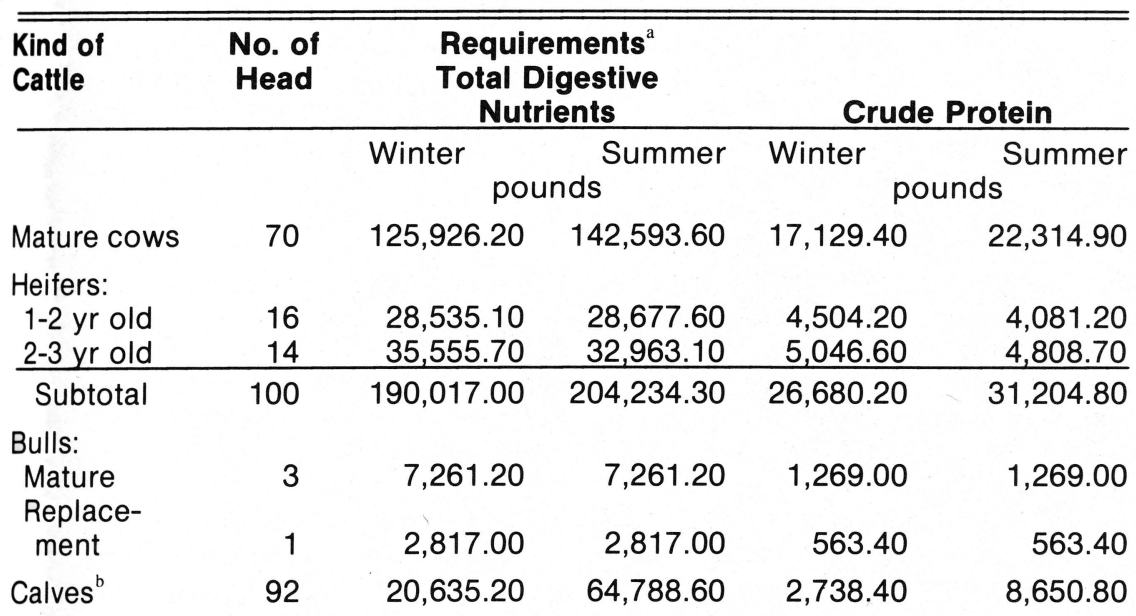

${ }^{a}$ The details of the monthly feed requirements are shown in Appendix Tables 17 and 18. Winter season is November through April; summer pasture season May through October.

${ }^{\text {h}}$ Requirements for 76 calves from birth to weaning and 16 replacement calves from birth to one year of age.

These nutritional needs of beef cattle were obtained from the Master's thesis of Donald M. Hulver. ${ }^{22}$

Capital borrowing costs were determined by using loan rates obtained from the Federal Land Bank. Adjustments in these rates were made to reflect the difference between explicit and implicit rates.

${ }^{19}$ Ronald A. Layton, Alfred L. Barr, and Paul E. Nesselroad, Estimated Annual Costs, Production, and Income for Selected Livestock and Crop Enterprises, Eastern West Virginia, West Virginia University Agricultural Experiment Station Bulletin 594T (Morgantown: West Virginia University, 1970), pp. 9-11.

${ }^{20}$ Dailey, Richard T., et al. Agricultural Planning Data for the Northeastern United States, The Pennsylvania State University, Department of Agricultural Economics and Rural Sociology, A.E. \& R.S. 51 (University Park: The Pennsylvania State University, 1965), Table 42, p. 71.

${ }^{21}$ Layton, et al, loc cit.

${ }^{22}$ Donald M. Hulver, "Total Digestible Nutrient Requirements for Beef Cattle During Growth, Gestation, and Lactation" (unpublished Master's thesis, West Virginia University, 1976). The information from this source is shown in Appendix Tables 17 and 18. 
To adjust prices paid by farmers, as indicated in previous research, to present prices and to project future prices, inflation values were determined ${ }^{23}$ using indexes of prices taken from USDA Agricultural Statistics ${ }^{24}$ and other USDA price bulletins.

\section{Analysis Procedure}

The analysis procedure consisted of the creation of a linear programming model which could be used to determine the minimum resource requirements at minimum cost for a $100 \mathrm{cow}$-calf beef herd. The model consisted of those resources and activities needed for feeder calf production. These were obtained from published research and estimates of qualified, experienced agricultural scientists. A generalized model was developed through the inclusion of those resources and activities which would enable the model to be applied to other areas of the State by adjusting only individual coefficients to reflect differences in soil types, input requirements, yields, and other production-related items.

The major resources for beef cattle production are land, labor, and capital. By combining these resources through the various activities, crops can be produced to provide the feed necessary to meet the nutritional requirements of the beef herd. Resources were assumed to have a beginning level of zero, except productive operator's labor, to show the total cost of starting and maintaining the operation through the purchase of all necessary resources. Operator's labor, however, was assumed to have an annual quantity available with no associated cost. Any additional labor needed was to be hired at the minimum wage. ${ }^{25}$

The percentage distribution of land by use and land capability class for the study area was used to determine what percent of an acre of purchased land would consist of the various uses and the different capability classes.

Capital needed to cover all costs of the beef production operation and resource acquisition was to be borrowed in order to include borrowing costs in the total minimum cost.

In addition to the major resources, other resources required were crop production machinery, the beef cow herd, and building space, including a silo when needed. The cost of these necessary resources was shown by allowing for purchase of these items.

The major activities consisted of crop production, livestock feeding, and acquisition of resources. Crop production activities included silage production, hay production, and pasture production. The livestock feeding activities consisted of the three alternative feeding systems: (1) feeding hay and pasture only, (2) feeding silage and pasture only, or (3) feeding a combination of silage and hay in addition to pasture. Acquisition of resources consisted of (1) buying land, (2) borrowing capital (long-term investment capital for land and buildings, intermediate-term capital for the purchase of

\footnotetext{
${ }^{23} \mathrm{An}$ inflation of 70.18 percent was determined by calculating an eleven-year moving average centered on the sixth year on price indexes of the years 1965-1975 (actual indexes were used for year 1970-75) and then calculating a linear regression problem to determine the equation of a line to project prices to 1985 .

${ }^{24}$ U.S. Department of Agriculture, Agricultural Statistics, Statistical Reporting Service (Washington, D.C.: U.S. Government Printing Office, 1975), Table 637, p. 455.

${ }^{25}$ U.S. Senate, Subcommittee on Labor, Fair Labor Standards Amendments of 1974, P.L. 93-259 (Washington, D.C.: U.S. Government Printing Office, April, 1974), p. 10.
} 
livestock and machinery, and short-term capital for operating expenses), (3) hiring labor for each season, (4) buying building space, and (5) buying crop production machinery. Acquiring the cow herd and constructing the silo were included in the livestock feeding activities in the linear programming matrix.

No attempt was made in the model to show a return or income level. The objective was limited to determining the minimum resource requirements and costs for different feeding methods. Knowledge of a return to the beef enterprise can be calculated by obtaining the market price for beef feeder calves and cull cows and bulls and applying it to the number of each produced. Income from the woodland should also be included in an analysis of total returns, but such analysis would also need to include the costs and labor involved to manage this portion of the business.

In order to determine the minimum resource requirements when considering future crop yields, provision had to be made for inflating present prices to future (1985) prices. The inflation rate used was determined by calculating an eleven-year moving average centered on the sixth year of yearly price indexes to give average indexes for the years 1965 through 1970. Actual indexes were used for the years 1971 through 1975. A linear regression was then calculated on these price indexes for the years 1965 through 1975 and an index projected for 1985 . This $1965-1975$ inflation rate (70.81 percent) was used for inflating all prices to be used in the future yield and price model.

The input-output relationships between the resources and activities were incorporated into a matrix. Each column represented the per unit specifications for each enterprise (activity) considered feasible. The matrix rows (resources) were the simultaneous equations solved considering resource constraints to obtain optimum solutions (minimum amount of resource required at minimum cost), except for those rows being used strictly for accounting purposes. The simultaneous equations were solved employing a standard linear programming computer program.

\section{PRESENTATION OF PROGRAMMING ANALYSIS}

The objective was to determine the minimum resource requirements at minimum cost for a 100 beef cow-calf enterprise. The resources needed were to be determined for each of three possible alternative feeding systems (1) hayand pasture-only, (2) silage- and pasture-only, and (3) a combination of silage and hay in addition to pasture. The feeding system which would result in the minimum cost was chosen from among these alternatives. After the minimum cost feeding system was chosen, minimum resource requirements for the remaining systems were determined individually. Quantity changes in fertilization rates and changes in prices (1975 prices were inflated 70.81 percent to estimate 1985 prices) were made and then the minimum cost system and its associated minimum resource requirements were again determined using estimated future crop yields and input prices. Again, after the minimum cost system was determined, minimum resource requirements for the remaining systems were determined for the future individually.

Various resources were estimated to be required in given quantities for a 100 -cow herd regardless, in some cases, of the feeding system used. Therefore, the quantities and values of those resources were unchanged from one system to another. Annual operator's labor available for productive work on crops and livestock was estimated to be 2,500 hours for each feeding 
system. Of this total, 1,249.80 hours were available as winter labor and 416.73 hours were available in each of the other three seasons. The winter season was six months (November 1-April 30) and each of the other seasons consisted of two months. Additional labor, if needed, was to be hired at $\$ 2.00$ per hour using present costs, and $\$ 3.42$ per hour at future costs. ${ }^{26}$ Livestock labor requirements were estimated to be equal for the feeding systems using silage. The hay-only system was estimated to require less labor.

Machinery complements ${ }^{27}$ were determined for each of the feeding systems based on the estimated machinery necessary for a 100-cow herd. All machinery was assumed to be purchased for ownership.

Building space was determined for a limited housing system regardless of the feeding system used. The required quantity estimated was $500 \mathrm{sq} . \mathrm{ft}^{28}$ at a present value of $\$ 2,120.00$ and a future value of $\$ 3,620.00$.

Livestock expenses were estimated through the compiling of a livestock budget. ${ }^{29}$ The silage-only feeding system was estimated to have the highest livestock expense with the combination system having slightly less due to a lower annual silo cost. The hay-only system had the lowest livestock expense, due mainly to less required feeding equipment in a no-silage system when using a 1,500-pound round bale haying system. Annual feed requirements in pounds of T.D.N. and C.P. ${ }^{30}$ for the $100-$ cow herd were the same for all three systems. In the combination feeding system, pounds of T.D.N. and C.P. were proportioned between silage and hay so the quantities required to meet feed needs were in a ratio of one pound of hay to two pounds of silage per cow per day. The investment needed for a 100-cow herd was based on 100-cow replacement units ${ }^{31}$ to include young breeding stock and bulls. The investment was estimated at $\$ 334.00$ per cow replacement unit. Future investment per unit was estimated at $\$ 570.51$ for a future herd value of $\$ 57,051.00$. Herd investment was the same regardless of the feeding system.

In all feeding systems, Class VII land could provide only unimproved pasture, and as indicated in the tables of results, all Class VI pasture chosen was improved even though unimproved Class VI was offered as an alternative. All pasture recovery was calculated at 75 percent with surplus pasture in one month being transferred to the next at less than a 100 percent rate. ${ }^{32}$ In the feeding sytems using hay, hayland was permitted to provide aftermath pasture.

\footnotetext{
${ }^{26}$ Labor was hired under the assumption that of every hour on the job only 75 percent would be productive. For example, in Table 1 results, 32.92 hours of hired labor $\times 25$ percent $=8.23$ hours of non-productive labor. Hence, the total labor of $2,111.21$ decreased by 8.23 leaves the remainder of $2,102.98$ and totals the labor spent on livestock and crops.

${ }^{27}$ Machinery complements and prices are given in Appendix Table 15.

${ }^{28}$ See footnote j., Appendix Table 16.

${ }^{29}$ The livestock budget is shown in Appendix Table 16. 18.

${ }^{30}$ Annual T.D.N. and C.P. requirements for the 100-cow herd are given in Appendix Tables 17 and

${ }^{31}$ The initial 100-cow herd required the purchase of 100 cows at $\$ 300.00$ per cow and four bulls at $\$ 850.00$ per bull. The herd in subsequent years would consist of 70 mature cows, fourteen three-yearolds, sixteen two-year-olds (heifers calve at 24 months of age with two first-calf heifers being culled each year), three mature bulls, and one replacement bull. Cows were estimated to have an eight-year productive life with 1.5 percent allowance for death loss. Bulls were estimated to have a six-year productive life.

${ }^{32}$ Surplus pasture was transferred at a 90 percent rate from May to June, June to July, and September to October. Transfer was at an 85 percent rate from July to August and August to September.
} 
The types of capital required were the same for all feeding systems. Investment capital provided for the purchase of land ${ }^{33}$ and buildings, intermediate capital provided for the purchase of machinery and livestock, and operating capital covered the annual operating expenses.

\section{Minimum Cost Solution: Silage- and Pasture-Only Feeding System -Present Crop Yields and Input Prices}

The minimum cost feeding system from among the three alternatives considered was the silage- and pasture-only system. The minimum resource requirements at lowest cost for the system supplying winter feed from silage alone was $\$ 526,664.24$ (Table 1 ), or an average of $\$ 5,266.64$ per cow. This includes the initial capital investment necessary to acquire the resources, animals, and machinery, as well as the cost of the first year's operation, and an interest charge for the use of each type capital. The quantities of capital required by type were as follows: (a) investment capital $\$ 398,830.90$, (b) intermediate capital $\$ 76,525.00$, and (c) operating capital $\$ 51,308.34$.

\section{Land and Building Investment}

The land required to satisfy winter feed requirements with silage-only was 714.1 acres at a value of $\$ 390,923.10$, which was 76 percent of the total cost. The total acreage separated into use components shows 107.83 acres of cropland, ${ }^{34} 196.37$ acres of pastureland, 400.6 acres of woodland, and 9.28 acres of farmstead. The total capital required for the land and building investment was $\$ 398,830.90$. The total for investment capital, including the building space cost was $\$ 2,120.00$, and a cement trench silo with approximately 600 tons of capacity cost $\$ 5,787.80 .^{35}$

\section{Machinery and Livestock Investment}

The machinery complement required for an all-silage winter feeding system had a present purchase value of $\$ 43,125.00$. The capital investment needed to acquire a 100 -cow replacement unit herd was $\$ 33,400.00$. The total amount of intermediate capital needed was $\$ 76,525.00$

\section{Labor Expense}

Available operator's labor for the spring season was not sufficient to meet spring labor needs, so 32.92 additional hours of labor was hired at a cost of $\$ 65.84$. In a practical situation, however, this small quantity of labor could be made up by the operator. Operator's labor for each of the remaining seasons

\footnotetext{
${ }^{33}$ All land was valued for Randolph County, 1976 , at $\$ 547.45$ per acre, present price. This was a calculated value based upon an average 1968-69 average value for sales in Randolph County of $\$ 163.69$ and adjusted to 1976 value using the 1976 average real estate value index for West Virginia. Through similar procedure it was estimated that the 1985 price would be $\$ 935.11$.

${ }^{34} \mathrm{Cropland}$ may be used as permanent pasture for all feeding systems. Cropland consisted of land Classes I, II, and III. Pastureland consisted of land Classes IV, VI, and VII.

${ }^{35} \mathrm{Calculation}$ of silo costs was made using information obtained in an interview with Dr. Gerald V. Eagan, Agricultural Economics Extension agent at WVU, and the publication: Silage and Silos, Pennsylvania State University College of Agriculture Extension Service Special Circular 80 (University Park: The Pennsylvania State University) p. 15. From these data, costs of approximately $\$ 9.70$ per ton for a 600 -ton capacity cement trench silo and $\$ 11.13$ per ton for a 250 -ton capacity cement trench silo for present costs were estimated.
} 
Table 1.

Minimum Resource Requirements for a 100 Beef Cow-Calf Herd, Winter Feed

Supplied by Silage; Summer Feed Supplied by Pasture: Present (1975-76) Crop Yields and Input Prices

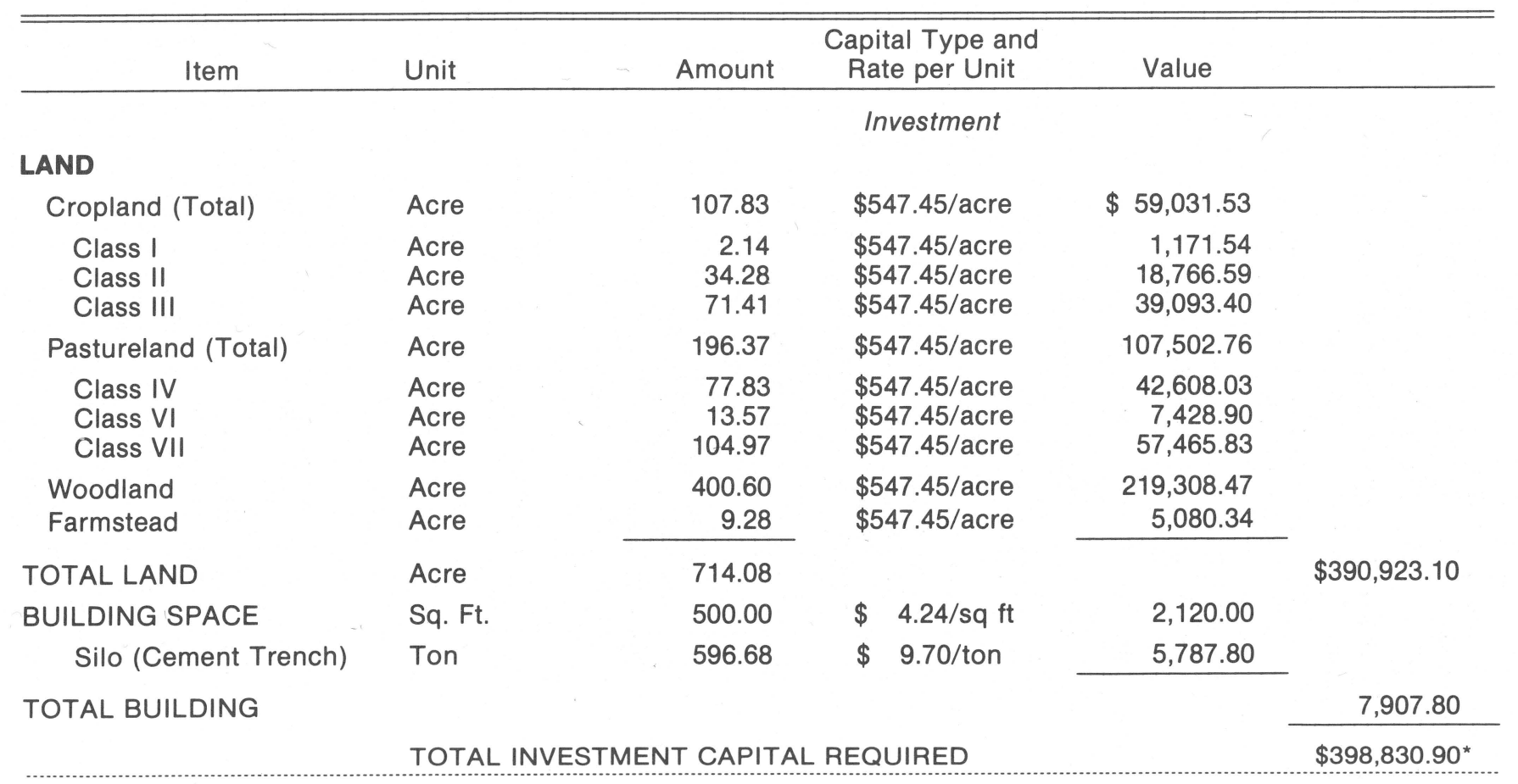




\begin{tabular}{|c|c|c|c|c|}
\hline & & & Intermediate & \\
\hline MACHINERY & Cow-mach unit & 100.00 & $\$ 431.25 /$ unit & $\$ 43,125.00$ \\
\hline LIVESTOCK & Cow-repl unit & 100.00 & $\$ 344.00$ /unit & $33,400.00$ \\
\hline
\end{tabular}

TOTAL INTERMEDIATE CAPITAL REQUIRED

\section{LABOR}

Spring laboroperator's

Extra spring labor hired

Hour

416.60

Summer laboroperator's

Hour

32.92

$\$ 2.00 /$ hour

65.84

Fall laboroperator's

Winter laboroperator's

Hour

177.88

Hour

323.81

Hour

$1,160.00$

TOTAL LABOR ${ }^{\mathrm{a}}$

Livestock labor

Hour

Hour

Hour

$1,620.00$
482.98

Crop labor

Hour

TOTAL PRODUCTIVE LABOR $^{\mathrm{a}}$ 
Table 1 Continued

\begin{tabular}{|c|c|c|c|c|c|c|c|}
\hline Item & Unit & Amount & $\begin{array}{l}\text { Capital Type and } \\
\text { Rate per Unit }\end{array}$ & \multicolumn{2}{|r|}{ Value } & & \\
\hline & \multicolumn{5}{|c|}{ Operating Expenses } & & \\
\hline LIVESTOCK EXPENSE & Cow repl unit & 100.00 & $\$ 52.14 /$ unit & $\$$ & $5,214.00$ & & \\
\hline \multicolumn{8}{|l|}{ CROP EXPENSE } \\
\hline \multicolumn{8}{|l|}{ Silage } \\
\hline $\begin{array}{l}\text { Corn } \\
\text { Corn }\end{array}$ & $\begin{array}{l}\text { Acre } \\
\text { Tons }\end{array}$ & $\begin{array}{r}28.77 \\
530.88\end{array}$ & & & & & \\
\hline $\begin{array}{l}\text { Rye } \\
\text { Rye }\end{array}$ & $\begin{array}{l}\text { Acre } \\
\text { Tons }\end{array}$ & $\begin{array}{l}28.77 \\
65.80\end{array}$ & & & & & \\
\hline $\begin{array}{l}\text { Class I Land } \\
\text { Class II Land }\end{array}$ & $\begin{array}{l}\text { Acre } \\
\text { Acre }\end{array}$ & $\begin{array}{r}2.14 \\
26.23\end{array}$ & $\begin{array}{r}\$ 222.36 / \text { acre } \\
222.36 / \text { acre }\end{array}$ & & $\begin{array}{r}475.85 \\
5,921.45 \\
\end{array}$ & & \\
\hline SILAGE OPERATING EXPE & & & & & & $\$$ & $6,397.30$ \\
\hline \multicolumn{8}{|c|}{ Pasture } \\
\hline Permanent Cropland & Acre & 79.05 & & & & & \\
\hline $\begin{array}{l}\text { Class II Land } \\
\text { Class III Land }\end{array}$ & $\begin{array}{l}\text { Acre } \\
\text { Acre }\end{array}$ & $\begin{array}{r}7.64 \\
71.41\end{array}$ & $\begin{array}{l}26.00 / \text { acre } \\
26.00 \text { /acre }\end{array}$ & & $\begin{array}{r}198.64 \\
1,856.66\end{array}$ & & \\
\hline Permanent Pastureland & Acre & 196.37 & & & & & \\
\hline $\begin{array}{l}\text { Class IV Land } \\
\text { Class VI Land } \\
\text { Class VII Land }\end{array}$ & $\begin{array}{l}\text { Acre } \\
\text { Acre } \\
\text { Acre }\end{array}$ & $\begin{array}{r}77.83 \\
13.57 \\
104.97\end{array}$ & $\begin{array}{r}26.00 / \text { acre } \\
26.00 / \text { acre } \\
3.90 / \text { acre }\end{array}$ & & $\begin{array}{r}2,023.58 \\
325.82 \\
409.38 \\
\end{array}$ & & \\
\hline \multicolumn{6}{|c|}{ PASTURE OPERATING EXPENSE } & $\$$ & $4,841.08$ \\
\hline TOTAL L & BOR, LIVESTC & AND CROF & OPERATING CAPITA & RE & EQUIRED & $\$$ & $16,518.22$ \\
\hline
\end{tabular}


Table 1 Continued

\begin{tabular}{|c|c|c|c|c|}
\hline Item & Unit & Amount & $\begin{array}{l}\text { Capital Type and } \\
\text { Rate per Unit }\end{array}$ & Value \\
\hline
\end{tabular}

\section{CAPITAL}

Interest on investment capital (land and buildings) $\$$

Interest on intermediate capital (machinery and livestock)

Interest on operating capital (operating

*Values marked by an asterisk were summed to obtain total initial capital investment and cost of first-year operations.

${ }^{\mathrm{a}}$ For explanation of labor procedure see footnote 26 . 
was sufficient. Livestock required 1,620 hours of the total labor and crop production required 482.98 hours.

\section{Livestock Expense}

Livestock operating expenses for the silage-only system were $\$ 52.14$ per cow replacement unit.

\section{Crops}

Winter feed needs required the production of 28.77 acres of silage, of which corn supplied 530.88 tons and a rye cover crop 65.8 tons. Silage production required 2.14 acres of Class I land and 26.63 acres of Class II land at a total operating cost of $\$ 6,397.30$.

Summer pasture production utilized 79.05 acres of cropland (Classes II and III only) as permanent pasture and 196.37 acres of permanent pastureland. All Class VI pastureland was improved pasture for all the feeding systems. All Class VII pasture was unimproved. Total pasture requirements for the sixmonth grazing season were 275.42 acres at an operating cost of $\$ 16,518.22$.

\section{Capital Costs}

In addition to the various quantities of capital needed, an interest charge was assessed for the use of the various types of capital. These interest costs were: (a) investment, $\$ 28,193.36$; (b) intermediate, $\$ 5,425.16$; and (c) operating, $\$ 1,171.14$. The total annual interest charge was $\$ 34,758.16$.

The total minimum cost of $\$ 526,664.24$ included all first-year costs and, therefore, represents a starting and first-year operational cost for the beef herd when using the silage- and pasture-only feeding system.

\section{Silage, Hay, and Pasture Feeding System- Present Crop Yields and Input Prices}

The silage, hay, and pasture feeding system was determined to have a cost between that of the other systems. The minimum cost of this system was $\$ 554,072.47$. This is $\$ 27,408.23$ more than the all-silage system and $\$ 19,315.86$ less than the all-hay system. Average investment per cow for the 100-cow replacement unit herd is $\$ 5,540.72$. This cost includes investment in all of the same items as in the all-silage system, plus those items necessary to make the hay required for a combination silage-hay system. The quantities of capital required are (a) investment capital, $\$ 410,244.47$; (b) intermediate, $\$ 88,305.00$; and (c) operating, $\$ 55,523.00$.

\section{Land and Building Investment}

The total land requirement for the winter feeding system of silage and hay was 740.65 acres at a value of $\$ 405,468.85$ (73 percent of the total cost). This combination system required 111.84 acres of cropland and 203.68 acres of pastureland. Woodland and farmstead were acquired in amounts of 415.50 acres and 9.63 acres, respectively. The total capital required for the land and building investment was $\$ 410,244.47$, which includes $\$ 2,655.62$ for a 239-ton capacity cement trench silo.

\section{Machinery and Livestock Investment}

The machinery complement for the combination feeding system required the greatest quantity of machinery items and, thus, had the highest cost, a value of 
Table 2.

Minimum Resource Requirements for a 100 Beef Cow-Calf Herd, Winter Feed

Supplied by Silage and Hay; Summer Feed Supplied by Pasture: Present Crop Yields and Input Prices

\begin{tabular}{|c|c|c|c|c|c|}
\hline Item & Unit & Amount & $\begin{array}{l}\text { Capital Type and } \\
\text { Rate per Unit }\end{array}$ & Value & \\
\hline & & & Investment & & \\
\hline \multicolumn{6}{|l|}{ LAND } \\
\hline Cropland (Total) & Acre & 111.84 & $\$ 547.45 /$ acre & $\$ 61,226.81$ & \\
\hline $\begin{array}{l}\text { Class I } \\
\text { Class II } \\
\text { Class III }\end{array}$ & $\begin{array}{l}\text { Acre } \\
\text { Acre } \\
\text { Acre }\end{array}$ & $\begin{array}{r}2.22 \\
35.55 \\
74.07\end{array}$ & $\begin{array}{l}\$ 547.45 / \text { acre } \\
\$ 547.45 / \text { acre } \\
\$ 547.45 / \text { acre }\end{array}$ & $\begin{array}{r}1,215.34 \\
19,461.85 \\
40,549.62\end{array}$ & \\
\hline Pastureland Total & Acre & 203.68 & $\$ 547.45 /$ acre & $111,504.62$ & \\
\hline $\begin{array}{l}\text { Class IV } \\
\text { Class VI } \\
\text { Class VII }\end{array}$ & $\begin{array}{l}\text { Acre } \\
\text { Acre } \\
\text { Acre }\end{array}$ & $\begin{array}{r}80.73 \\
14.07 \\
108.88\end{array}$ & $\begin{array}{l}\$ 547.45 / \text { acre } \\
\$ 547.45 / \text { acre } \\
\$ 547.45 / \text { acre }\end{array}$ & $\begin{array}{r}44,195.64 \\
7,702.62 \\
59,606.36\end{array}$ & \\
\hline Woodland & Acre & 415.50 & $\$ 547.45 /$ acre & $227,465.48$ & \\
\hline Farmstead & Acre & 9.63 & $\$ 547.45 /$ acre & $5,271.94$ & \\
\hline TOTAL LAND & Acre & 740.65 & & & $405,468.85$ \\
\hline BULDING SPACE & Sq.Ft. & 500.00 & $4.24 / \mathrm{sq} f t$. & $2,120.00$ & \\
\hline Silo (Cement Trench) & Ton & 238.6 & $\$ 11.13 /$ ton & $2,655.62$ & \\
\hline \multirow[t]{2}{*}{ TOTAL BUILDING } & & & & & $4,775.62$ \\
\hline & \multicolumn{4}{|c|}{ TOTAL INVESTMENT CAPITAL REQUIRED } & $\$ 410,244.47$ \\
\hline
\end{tabular}


Table 2 Continued

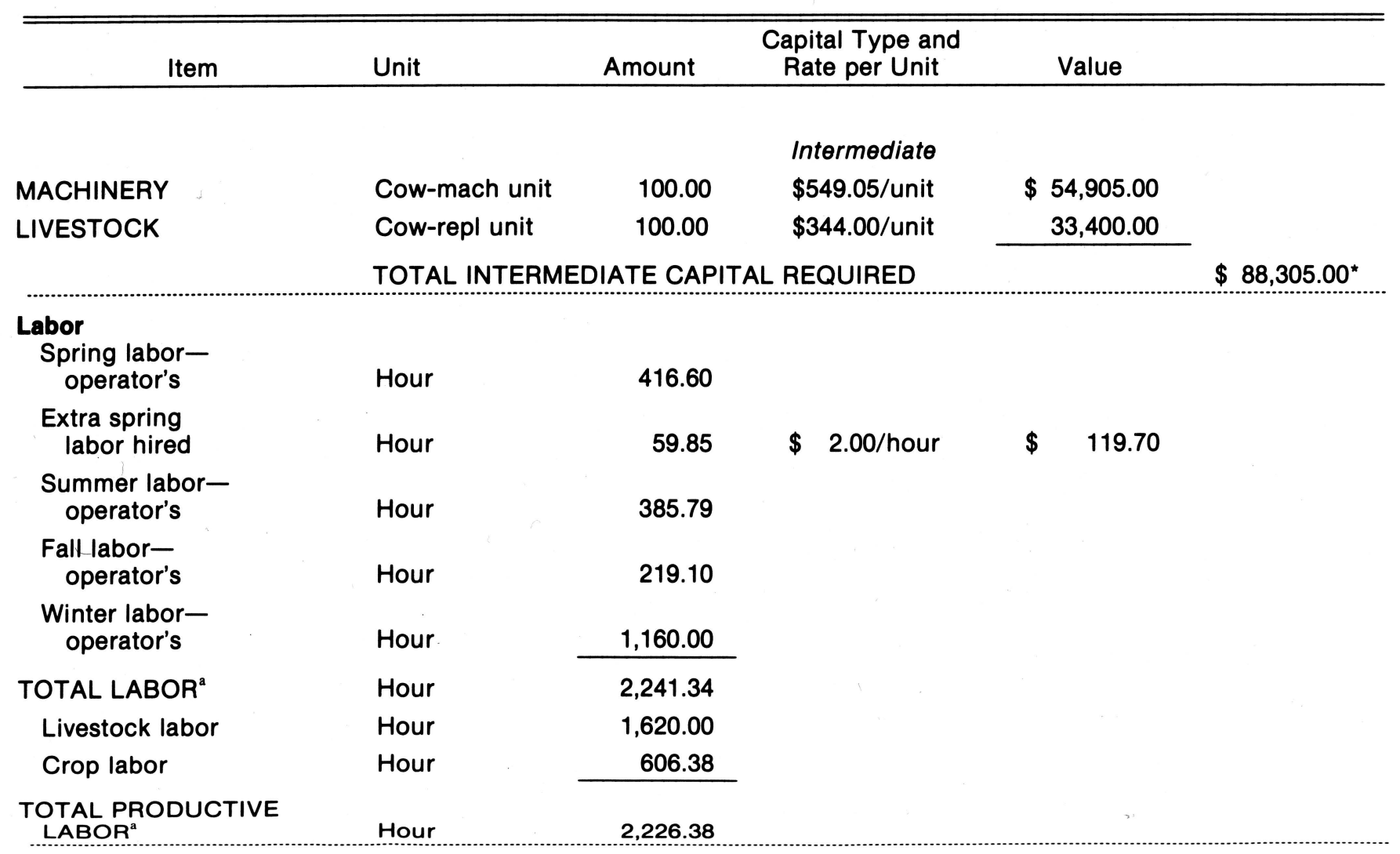


Table 2 Continued

\begin{tabular}{|c|c|c|c|c|c|}
\hline Item & Unit & Amount & $\begin{array}{l}\text { Capital Type and } \\
\text { Rate per Unit }\end{array}$ & & Value \\
\hline & & \multicolumn{4}{|c|}{ Operating Expenses } \\
\hline LIVESTOCK EXPENSE & Cow repl unit & 100.00 & $\$ 48.32 /$ unit & $\$$ & $4,832.00$ \\
\hline \multicolumn{6}{|l|}{ CROP EXPENSE } \\
\hline $\begin{array}{l}\text { Silage } \\
\text { Corn } \\
\text { Corn }\end{array}$ & $\begin{array}{l}\text { Acre } \\
\text { Ton }\end{array}$ & $\begin{array}{r}11.44 \\
212.32\end{array}$ & & & \\
\hline $\begin{array}{l}\text { Rye } \\
\text { Rye }\end{array}$ & $\begin{array}{l}\text { Acre } \\
\text { Ton }\end{array}$ & $\begin{array}{l}11.44 \\
26.28\end{array}$ & & & \\
\hline $\begin{array}{l}\text { Class I Land } \\
\text { Class II Land }\end{array}$ & $\begin{array}{l}\text { Acre } \\
\text { Acre }\end{array}$ & $\begin{array}{l}2.22 \\
9.22\end{array}$ & $\begin{array}{l}22.36 / \text { acre } \\
22.36 \text { /acre }\end{array}$ & $\$$ & $\begin{array}{r}493.64 \\
2,050.16 \\
\end{array}$ \\
\hline \multicolumn{2}{|c|}{ SILAGE OPERATING EXPENSE } & & & $\$$ & $2,543.80$ \\
\hline $\begin{array}{l}\text { Hay } \\
\text { Alfalfa-Timothy- } \\
\text { Orchard }\end{array}$ & Acre & 49.04 & & & \\
\hline $\begin{array}{l}\text { Alfalfa-Timothy } \\
\text { Orchard }\end{array}$ & Ton & 114.15 & & & \\
\hline \multicolumn{6}{|l|}{$\begin{array}{l}\text { Total Establishment } \\
\text { Cost in Year } 1\end{array}$} \\
\hline $\begin{array}{l}\text { Class II } \\
\text { Class III }\end{array}$ & $\begin{array}{l}\text { Acre } \\
\text { Acre }\end{array}$ & $\begin{array}{l}26.33 \\
22.71\end{array}$ & $\begin{array}{l}\text { 146.83/acre } \\
146.83 \text { /acre }\end{array}$ & $\$$ & $\begin{array}{l}3,866.03 \\
3,334.51\end{array}$ \\
\hline \multicolumn{4}{|c|}{ ESTABLISHMENT COST CHARGED TO FIRST YEAR } & $\$$ & $7,200.54$ \\
\hline
\end{tabular}


Table 2 Continued

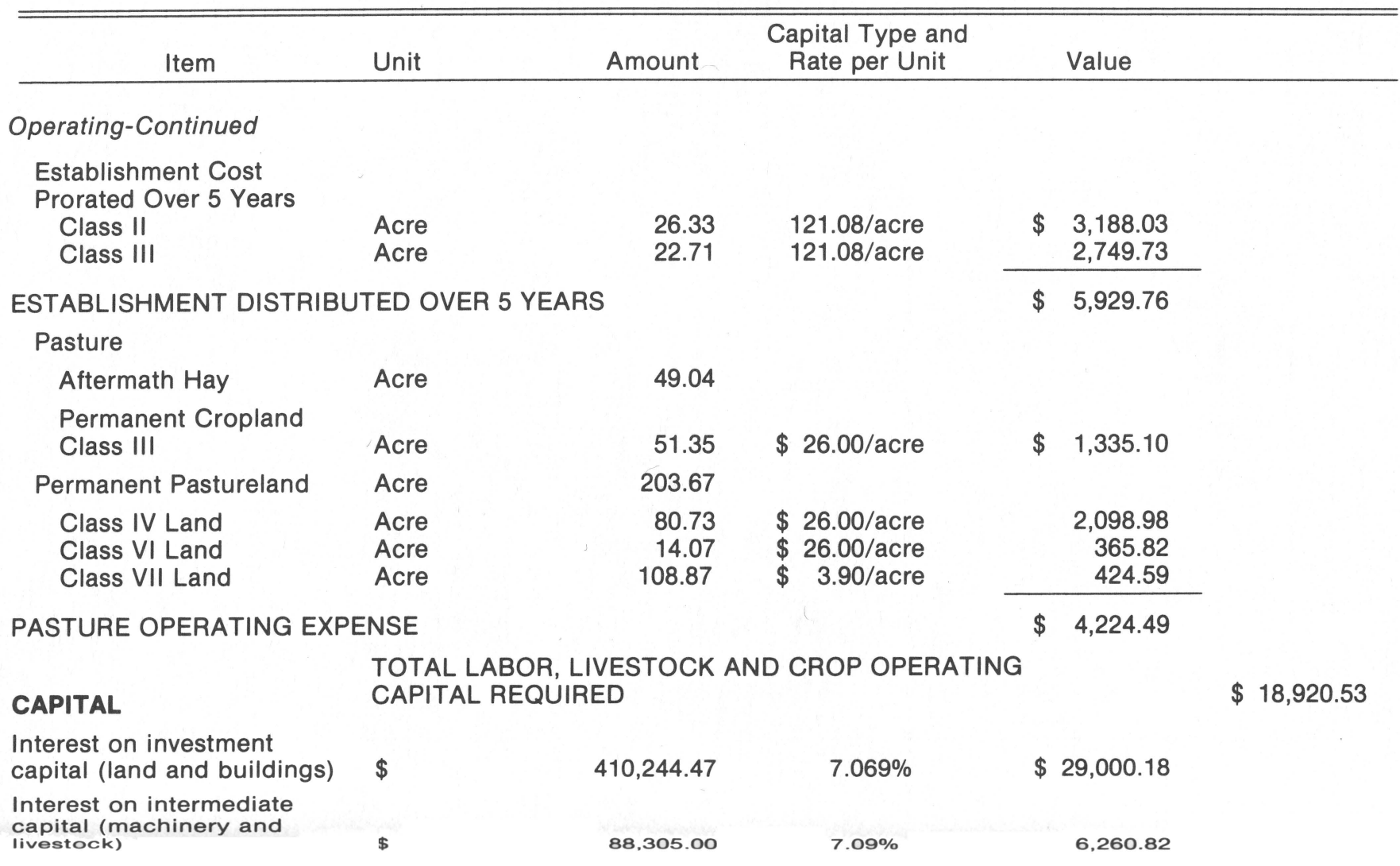


Table 2 Continued

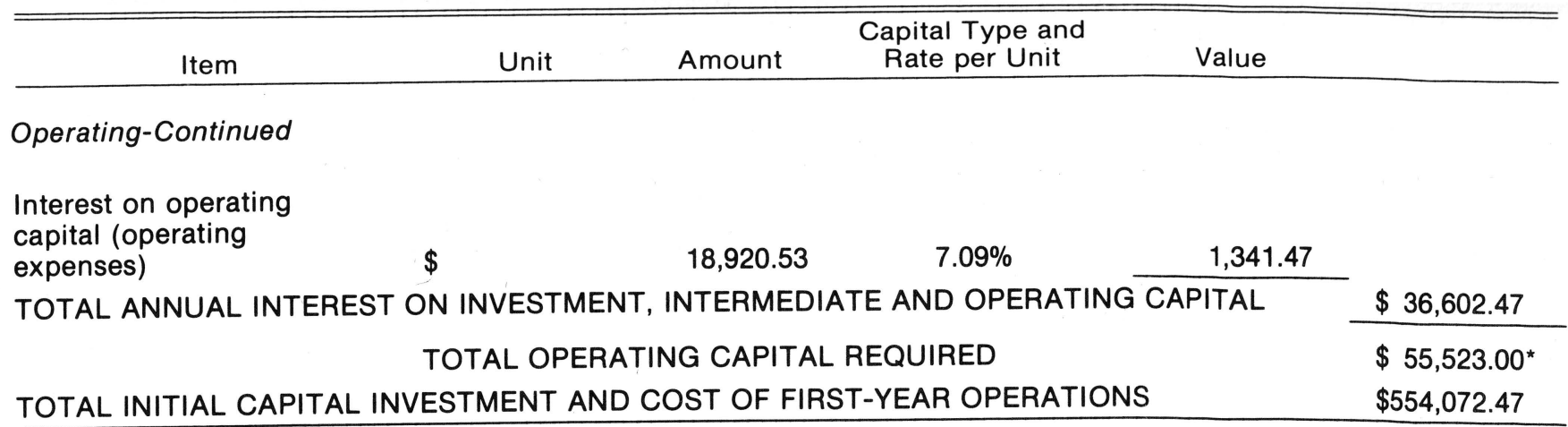

N Values marked by an asterisk were summed to obtain total initial capital investment and cost of first-year operations.

${ }^{\mathrm{a}}$ For explanation of labor procedure see footnote 26 . 
$\$ 54,905.00$. The capital investment needed to acquire a 100 -cow replacement unit herd was $\$ 33,400.00$, as with the other feeding systems. The intermediate capital needed was $\$ 88,305.00$.

\section{Labor Expense}

Operator's available labor was sufficient in all seasons except the spring, and even then it was only necessary to hire approximately 60 hours of additional labor. This would require only a small outlay of operating expense money, and in all likelihood the operator and/or his family would eliminate the need to hire any labor. Productive labor requirements by uses were 1,620 hours for livestock production and 606 hours for crop production.

\section{Livestock Expense}

Livestock expenses in the combination feeding system were estimated to be less than those of the silage-only winter feeding system, due to the lower silo annual cost. Round bale hay feeding equipment was estimated not to greatly affect the equipment requirements when silage feeding equipment was required. Livestock expenses for the combination system were $\$ 48.32$ per cow replacement unit, giving a herd cost of $\$ 4,832.00$.

\section{Crops}

Only two types of crops would be grown, silage and hay. Silage production involves equal quantities of work each crop production season, while hay production requires additional labor to initially establish the hay stand. This additional labor is primarily land preparation and seeding, and would only be required one time for a period of several years. In this study the hay stand life was estimated to be an average of five years. Not all hay would be seeded the same year, therefore labor requirements for hay seeding would only occur every five years and for approximately 20 percent on the hay-producing land. Hay seeding labor should be prorated over the life of the stand rather than charged to a single year.

Just as seeding labor could be charged on a prorated basis, the initial seeding costs could be prorated over the life of the hay stand. The cost per acre of seeding hay was budgeted at $\$ 146.83$ but the initial seeding cost prorated over a five-year stand life plus annual maintenance of the stand would be $\$ 121.08$ per acre. Since this report was based on the first year of operation, the operating expense was figured on the $\$ 146.83$ per acre.

Winter feed needs using silage and hay required the production of 11.44 acres of corn silage. Corn provided 212.32 tons and the rye cover crop provided 26.28 tons of silage. Silage production utilized 2.22 acres of Class 1 land and 9.22 acres of Class II land at a total operating cost of $\$ 2,543.80$.

Hay production used 49.04 acres of land to produce 114.15 tons of alfalfagrass hay. Hay was produced on 26.33 acres of Class II land and 22.71 acres of Class III land. The hay on Class II land utilized the remaining acreage of that land not in silage, and about one-third of the available Class III land.

Pasture production required 304.06 acres of which 49.04 acres were aftermath pasture from hayland. The operating cost of pasture production was $\$ 4,224.49$. In addition to aftermath pasture, 51.35 Class III cropland acres provided permanent pasture, and pastureland provided 203.67 acres of permanent pasture. All Class IV and VI land used provided improved pasture. Class VII pasture was unimproved. 


\section{Capital}

Capital requirements for the silage, hay, and pasture-feeding system were: investment capital- $\$ 410,244.47$ at an interest cost of $\$ 29,000.18$; intermediate capital- $\$ 88,305.00$ at an interest cost of $\$ 6,260.82$; operating capital$\$ 18,920.53$ at an interest cost of $\$ 1,341.47$ when hay establishment costs were included in the first year.

The total minimum cost of the minimum resource requirements for a combination feeding system was $\$ 554,072.47$. Hay establishment costs and other first-year costs were included in this total, thus, this figure represents the starting and first year's operating cost of a $100 \mathrm{cow}$-calf beef herd when winter feeding a combination of silage and hay.

\section{Hay- and Pasture-Only Feeding System- Present Crop Yields and Input Prices}

The minimum resource requirements at least cost for a feeding system which supplies winter feed needs with hay only are shown in Table 3. The hay-only system was determined to have the highest minimum cost of the three present feeding systems considered. The total cost for this system was $\$ 573,388.33$, which was $\$ 46,756.05$ higher than the silage-only system. Average investment per cow replacement unit was $\$ 5,733.88$. The distribution of capital requirements was (a) investment, $\$ 441,596.44$; (b) intermediate, $\$ 74,056.00$; and (c) operating, $\$ 57,735.89$.

\section{Land and Building Investment}

The hay- and pasture-only feeding system needed 802.77 acres of total farm land at a value of $\$ 439,476.44$, which was 77 percent of the total cost. The quantity of land required for crop and pasture land to support the respective beef feeding systems accounts for the largest amount of the cost differential between systems. The hay-only system requires the largest amount of cropland and pastureland resulting in the large percentage of the capital invested in land only. Cropland required 121.22 acres and pastureland required 220.76 acres of the total. Purchase of the required cropland and pastureland resulted in 450.35 acres of woodland and 10.44 acres for farmstead being part of the package. This feeding plan had the smallest building cost, $\$ 2,120.00$, of the three feeding systems studied since a silo was not required.

\section{Machinery and Livestock Investment}

The hay- and pasture-only feeding system required a machinery complement with a value of $\$ 40,656.00$, cheapest of the three machinery packages. The feeding system assumed a round bale method of hay production, which not only changed the machinery complement from that of silage-only, but also reduced livestock feeding equipment needs in the hayonly system as will be shown in Livestock Expenses. The capital investment needed for a 100 -cow replacement unit herd was $\$ 33,400.00$. The total amount of intermediate capital needed was $\$ 74,056.00$.

\section{Labor Expense}

Available operator's labor for both spring and summer was insufficient to meet the labor needs of these seasons. An additional 173.37 hours of spring 
Table 3.

Minimum Resource Requirements for a 100 Beef Cow-Calf Herd, Winter Feed

Supplied by Hay; Summer Feed Supplied by Pasture: Present Crop Yields and Input Prices

\begin{tabular}{|c|c|c|c|c|c|}
\hline Item & Unit & Amount & $\begin{array}{l}\text { Capital Type and } \\
\text { Rate per Unit }\end{array}$ & Value & \\
\hline & \multicolumn{5}{|c|}{ Investment } \\
\hline $\begin{array}{l}\text { LAND } \\
\text { Cropland }\end{array}$ & Acre & 121.22 & $\$ 547.45 /$ acre & $\$ 66,361.89$ & \\
\hline $\begin{array}{l}\text { Class I } \\
\text { Class II } \\
\text { Class III }\end{array}$ & $\begin{array}{l}\text { Acre } \\
\text { Acre } \\
\text { Acre }\end{array}$ & $\begin{array}{r}2.41 \\
38.53 \\
80.28\end{array}$ & $\begin{array}{l}\text { \$547.45/acre } \\
\text { \$547.45/acre } \\
\text { \$547.45/acre }\end{array}$ & $\begin{array}{r}1,319.35 \\
21,093.25 \\
43,949.29\end{array}$ & \\
\hline Pastureland & Acre & 220.76 & $\$ 547.45 /$ acre & $120,855.06$ & \\
\hline $\begin{array}{l}\text { Class IV } \\
\text { Class VI } \\
\text { Class VII }\end{array}$ & $\begin{array}{l}\text { Acre } \\
\text { Acre } \\
\text { Acre }\end{array}$ & $\begin{array}{r}87.50 \\
15.25 \\
118.01\end{array}$ & $\begin{array}{l}\$ 547.45 / \text { acre } \\
\$ 547.45 / \text { acre } \\
\$ 547.45 / \text { acre }\end{array}$ & $\begin{array}{r}47,901.88 \\
8,348.61 \\
64,604.57\end{array}$ & \\
\hline Woodland & Acre & 450.35 & $\$ 547.45 /$ acre & $246,544.11$ & \\
\hline Farmstead & Acre & 10.44 & $\$ 547.45 /$ acre & $5,715.38$ & \\
\hline TOTAL LAND & Acre & 802.77 & & & $439,476.44$ \\
\hline \multirow[t]{2}{*}{ BUILDING SPACE } & Sq Ft. & 500.00 & $\$ 4.24 / \mathrm{sq} \mathrm{ft}$ & $2,120.00$ & \\
\hline & \multicolumn{4}{|c|}{ TOTAL INVESTMENT CAPITAL REQUIRED } & $\$ 441,596.44^{*}$ \\
\hline & & & Intermediate & & \multirow{3}{*}{$\$ 74,056.00^{*}$} \\
\hline \multirow{2}{*}{$\begin{array}{l}\text { MACHINERY } \\
\text { LIVESTOCK }\end{array}$} & Cow-mach unit & 100.00 & $\$ 406.56 /$ unit & $\$ 40,656.00$ & \\
\hline & Cow-repl unit & 100.00 & $\$ 344.00 /$ unit & $33,400.00$ & \\
\hline
\end{tabular}




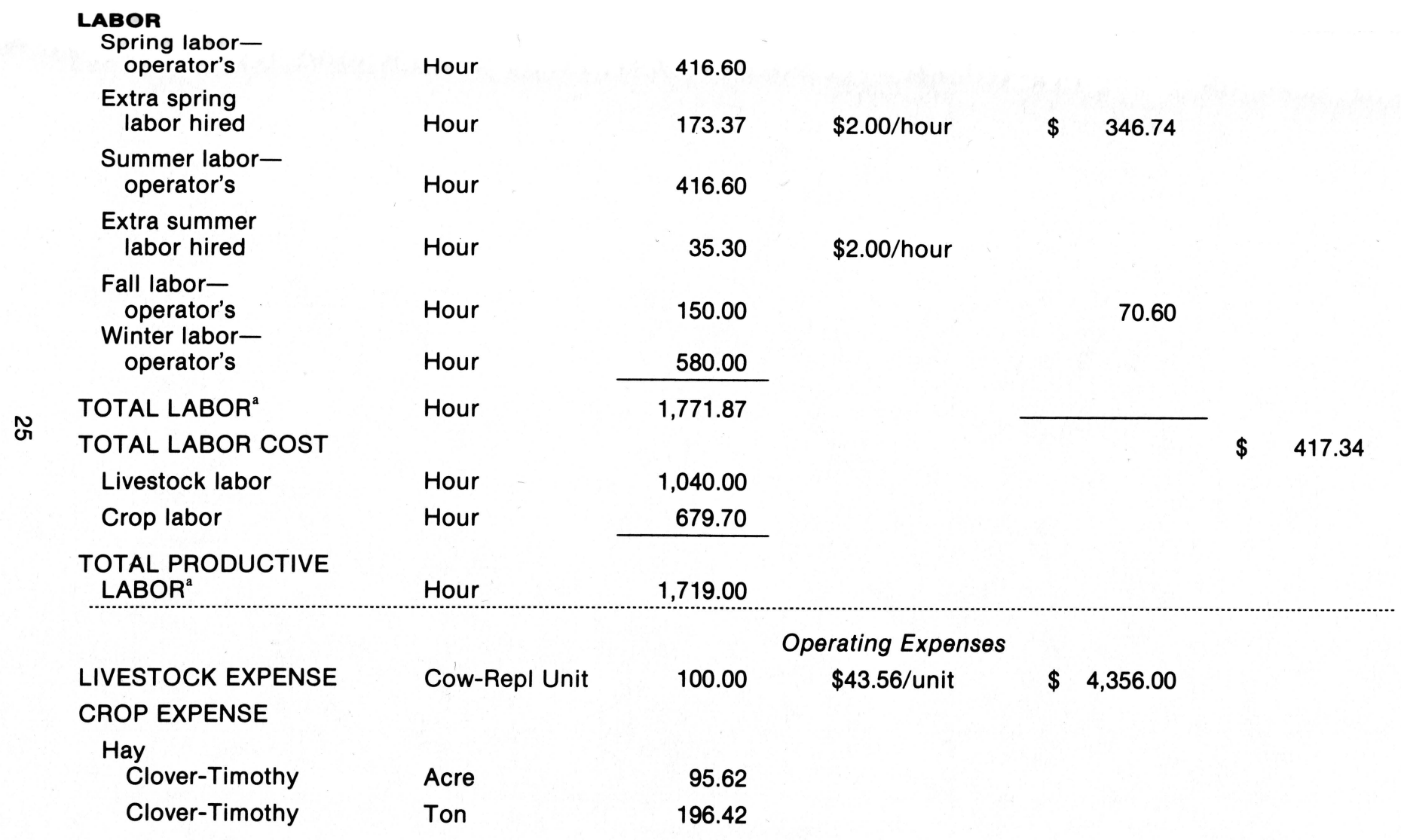




\section{Table 3 Continued}

\begin{tabular}{ccccc}
\hline \hline Item & Unit & Capital Type and & Ralue \\
\hline
\end{tabular}

Operating-Continued

Alfalfa-Timothy

Orchard

Acre

8.43

Alfalfa-Timothy

Orchard

Total Establishment

Cost in year 1

ก

Class I Clover

Class II Clover

Class III

Clover

Alfalfa

Acre

2.41

Acre

38.53

$\$ 107.42 /$ acre

\$ 258.88

$107.42 /$ acre

$4,138.89$

Acre $\quad 54.68 \quad \$ 107.42 /$ acre

Acre

8.43

ESTABLISHMENT COST CHARGED TO FIRST YEAR

Establishment cost

prorated over 5 years

Class I Clover

Class II Clover

Class 'II

Clover

Alfalfa

Acre

Acre

2.41

38.53

Acre

Acre

54.68

8.43

ESTABLISHMENT DISTRIBUTED OVER 5 YEARS

\section{PASTURE}

Aftermath Hay

Acre

104.05
$\$ 146.83 /$ acre

$\$ \quad 5,873.73$ $1,237.78$

$\$ 11,509.28$

$\$ 99.37 /$ acre

$\$ 99.37 /$ acre

$\$ 99.37 /$ acre

$\$ 121.08$ /acre

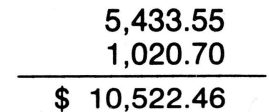




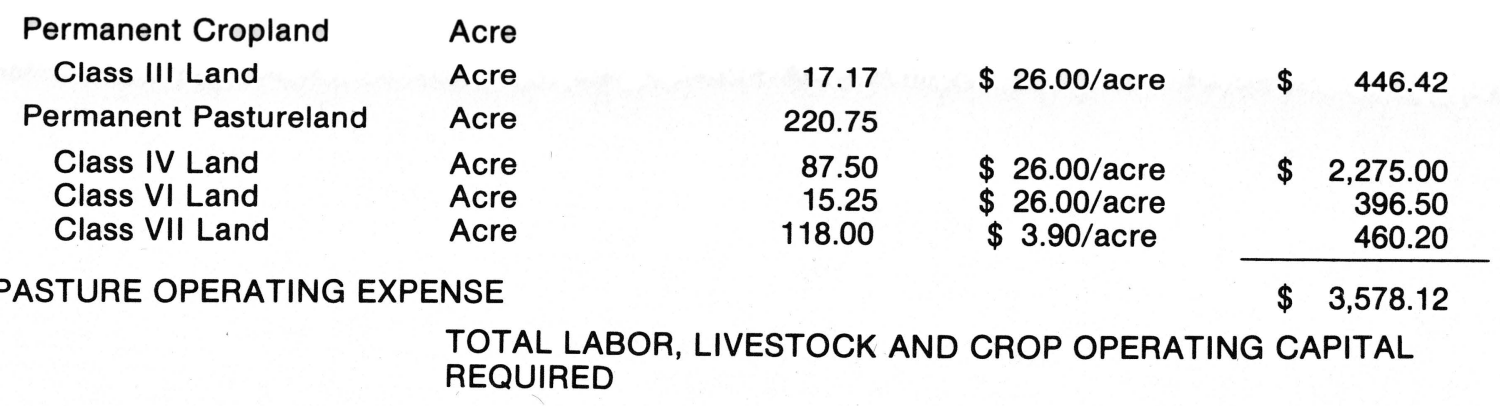

$\$ 19,860.74$

\section{CAPITAL}

Interest on investment capital (land and buildings)

$\sim$ Interest on intermediate capital (machinery and livestock)

$$
\begin{array}{lll}
441,596.77 & 7.069 \% & \$ 31,216.45
\end{array}
$$

$$
74,056.00
$$

$$
7.09 \%
$$

$\$ \quad 5,250.57$

Interest on operating capital (operating expenses)

TOTAL ANNUAL INTEREST ON INVESTMENT, INTERMEDIATE AND OPERATING CAPITAL

*Values marked by an asterisk were summed to obtain total initial capital investment and cost of first-year operations.

${ }^{a}$ For explanation of labor procedure see footnote 26. 
labor and 35.30 hours of summer labor were required. The extra spring labor requirements included the costs of hay establishment in the first year. The additional 208.67 hours of labor cost $\$ 417.34$. Fall and winter available operator's labor was sufficient for those seasons. Livestock required $1,040.00$ hours of productive labor and crop production required 679.70 hours, with hay establishment costs included in year one.

\section{Livestock Expense}

Livestock expenses for the hay-only winter feeding system were $\$ 43.56$ per cow replacement unit which was less than for the silage-only system. Total herd cost of the livestock expenses was $\$ 4,356.00$.

\section{Crops}

Clover-timothy hay was chosen to satisfy the winter feed requirements in the hay- and pasture-only feeding system. Hay production required 104.05 acres, and provided 215.13 tons of clover-timothy hay. The operating cost of hay production on the required acreage was $\$ 11,509.28$ when hay establishment costs were included in the first year. The operating cost when prorating establishment costs was $\$ 10,522.46$.

Pasture production required 341.97 acres of land at an annual operating cost of $\$ 3,578.12$, including aftermath pasture from the 104.05 acres of hayland. Permanent pasture from cropland, Class III, required 17.17 acres and permanent pastureland provided 220.75 acres of pasture. All pasture on Class IV and VI land was improved and all Class VII pasture was unimproved.

\section{Capital}

Capital requirements for the hay- and pasture-only feeding system were: Investment capital- $\$ 441,596.44$ at an interest cost of $\$ 31,216.45$; intermediate capital- $\$ 74,056.00$ at an interest cost of $\$ 5,250.57$; operating capital$\$ 19,860.74$ at an interest cost of $\$ 1,408.13$ when hay establishment costs were included in the first year.

The total minimum cost of $\$ 573,388.33$ includes hay establishment costs in year one in addition to other first-year costs and, thus, represents the starting and operating cost for the hay-only system. The hay-only system was the most expensive of the three systems studied primarily because of the larger acreage of land required to produce the feed necessary for the herd.

\section{Minimum Cost of Resource Requirement for 1985}

The model projecting the minimum cost of resources for the year 1985 was the same as for 1976 except the cost reflects: (a) the effect of the projected inflation rate for 1985, and (b) the anticipated reduction in land requirements due to increased yield for forage crops obtained through increased fertilizer and lime usage. No examination of improved yields of forages through genetic improvements or increased efficiency of feed conversion by forageconsuming livestock was made.

\section{Minimum Cost Solution: Silage- and Pasture-Only Feeding System- Future (1985) Crop Yields and Input Prices}

The minimum cost feeding system when all three systems were specified, using estimated future crop yields and input prices, was determined to be the silage- and pasture-only system. This shows the same result as the model 
using present yields and prices. The minimum resource requirements for the silage-only winter feeding system are shown in Table 4 and have a cost of $\$ 689,386.98$, giving a per cow replacement unit investment of $\$ 6,893.86$. The future system assumes increased crop yields as shown in Appendix Table 4.

\section{Land and Buildings Investment}

Land cost for 1985 was determined by inflating present land cost by a 70.81 percent inflation rate giving a future land cost of $\$ 935.11$ per acre. The total land requirement of the future silage- and pasture-only feeding system would be 476.03 acres at a value of $\$ 445,140.41$ (65 percent of the total cost). This is a reduction of 238 acres (33 percent) less than the same silage-pasture system results for 1976 . The acreage reduction is due solely to improved crop and pasture yields expected over the next ten years. In spite of the decreased required acreage, the capital required for land investment was $\$ 54,217$ greater due to anticipated increase in land values expected by 1985 . The required quantities of cropland and pastureland would be 71.88 acres and 130.91 acres, respectively. Woodland and farmstead would be acquired in amounts of 267.05 acres and 6.19 acres, respectively. The total capital required for the land and building investment would be $\$ 458,643.26$ which includes $\$ 9,882.85$ for a 596 ton capacity cement trench silo.

\section{Machinery and Livestock Investment}

The machinery complement required for the future silage-only winter feeding system was assumed to be the same as when using present yields and prices. The value of the machinery complement, after making the necessary inflationary adjustment, would be $\$ 73,662.00$. The capital investment needed to acquire a 100 -cow replacement unit herd would be $\$ 57,051.00$. The total amount of intermediate capital needed would be $\$ 130,713.00$.

\section{Labor Expense}

Available operator's labor would be sufficient to meet the labor requirements in all seasons, so the hiring of additional labor would not be necessary. Livestock would require 1,620.00 productive hours of labor and crop production 321.86 hours.

\section{Livestock Expense}

Livestock operating expenses for this future feeding system were estimated to be $\$ 89.06$ per cow replacement.

\section{Crops}

The production of 19.17 acres of silage would be required to meet the winter feed requirements when using the silage-only system. Corn would provide 530.65 tons of silage and the rye cover crop 65.78 tons. Production of silage would require 1.43 acres of Class I land and 17.74 acres of Class II land at a total operating cost of $\$ 8,750.53$.

Pasture production to satisfy spring, summer, and fall feed requirements would require 52.70 acres of permanent cropland pasture (Classes II and III only) and 130.91 acres of permanent pastureland. Total pasture needed for the six-month grazing season would be 183.61 acres at an operating cost of $\$ 8,058.82$. Class VI pasture, again, would all be improved and Class VII pasture would be unimproved. 
Table 4.

Minimum Resource Requirements for a 100 Beef Cow-Calf Herd, Winter Feed

Supplied by Silage; Summer Feed Supplied by Pasture: Future (1985) Crop Yields and Input Prices

\begin{tabular}{|c|c|c|c|c|c|}
\hline Item & Unit & Amount & $\begin{array}{c}\text { Capital Type and } \\
\text { Rate per Unit }\end{array}$ & Value & \\
\hline & & & Investment & & \\
\hline \multicolumn{6}{|l|}{ LAND } \\
\hline Cropland (Total) & Acre & 71.88 & $\$ 935.11 /$ acre & $\$ 67,215.71$ & \\
\hline $\begin{array}{l}\text { Class I } \\
\text { Class II } \\
\text { Class III }\end{array}$ & $\begin{array}{l}\text { Acre } \\
\text { Acre } \\
\text { Acre }\end{array}$ & $\begin{array}{r}1.43 \\
22.85 \\
47.60\end{array}$ & $\begin{array}{l}\$ 935.11 / \text { acre } \\
\$ 935.11 / \text { acre } \\
\$ 935.11 / \text { acre }\end{array}$ & $\begin{array}{r}1,337.21 \\
21,367.26 \\
44,511.24\end{array}$ & \\
\hline Pastureland (Total) & Acre & 130.91 & $\$ 935.11 /$ acre & $122,415.25$ & \\
\hline $\begin{array}{l}\text { Class IV } \\
\text { Class VI } \\
\text { Class VII }\end{array}$ & $\begin{array}{l}\text { Acre } \\
\text { Acre } \\
\text { Acre }\end{array}$ & $\begin{array}{r}51.89 \\
9.04 \\
69.98\end{array}$ & $\begin{array}{l}\$ 935.11 / \text { acre } \\
\$ 935.11 / \text { acre } \\
\$ 935.11 / \text { acre }\end{array}$ & $\begin{array}{r}48,522.86 \\
8,453.39 \\
65,439.00\end{array}$ & \\
\hline Woodland & Acre & 267.05 & $\$ 935.11 /$ acre & $249,721.12$ & \\
\hline Farmstead & Acre & 6.19 & $\$ 935.11 /$ acre & $5,788.33$ & \\
\hline TOTAL LAND & Acre & 476.03 & & & $\$ 445,140.41$ \\
\hline BUILDING SPACE & Sq Ft. & 500.00 & $7.24 / \mathrm{sq} \mathrm{ft}$ & $3,620.00$ & \\
\hline Silo (Cement Trench) & Ton & 596.43 & $16.57 /$ ton & $9,882.85$ & \\
\hline \multirow[t]{2}{*}{ TOTAL BUILDING } & & & & & $13,502.85$ \\
\hline & \multicolumn{4}{|c|}{ TOTAL INVESTMENT CAPITAL REQUIRED } & $\$ 458.643 .26^{*}$ \\
\hline
\end{tabular}




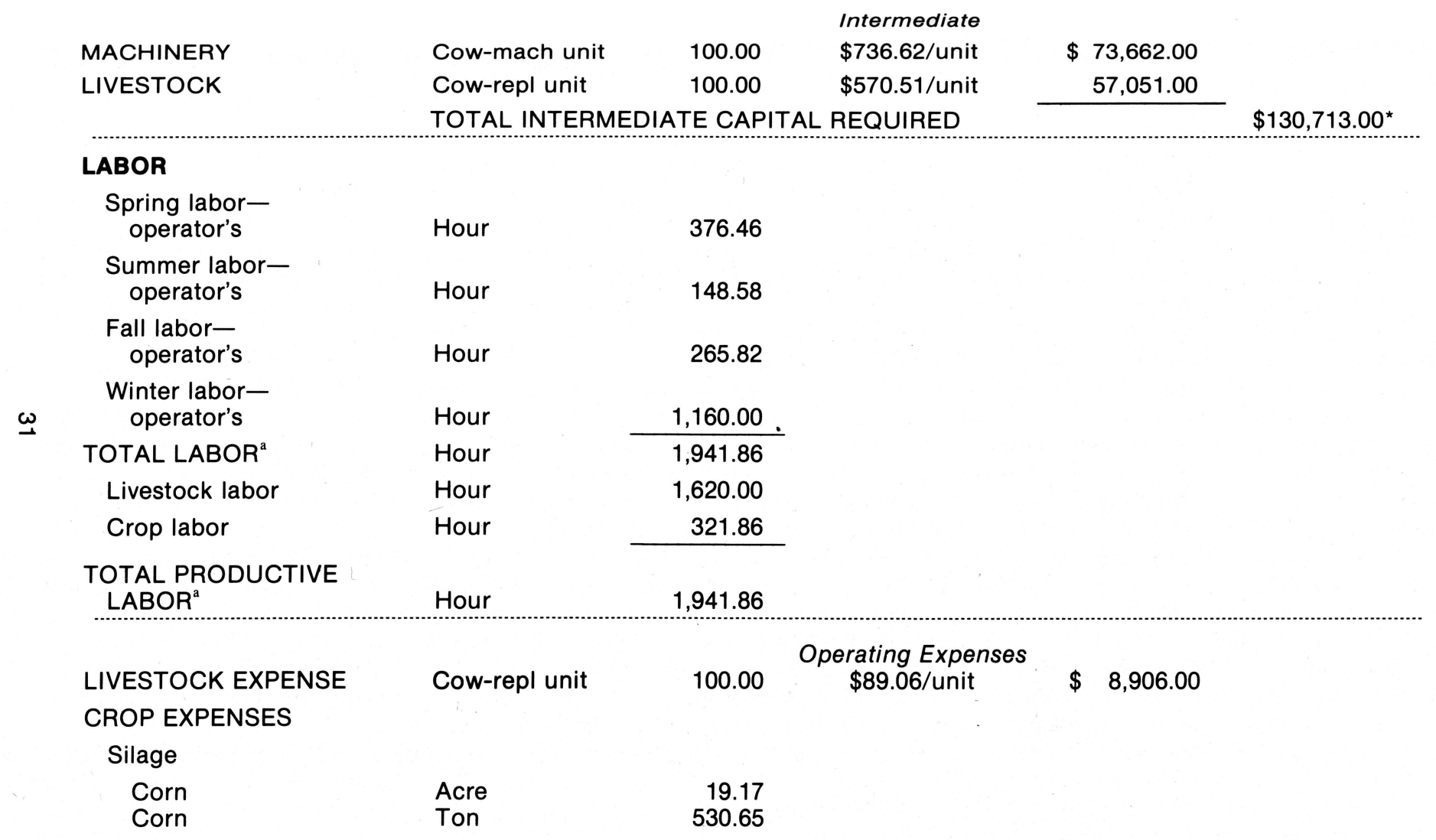




\section{Table 4 Continued}

\begin{tabular}{|c|c|c|c|c|}
\hline Item & Unit & Amount & $\begin{array}{l}\text { Capital Type and } \\
\text { Rate per Unit }\end{array}$ & Value \\
\hline
\end{tabular}

Operating-Continued

\begin{tabular}{|c|c|c|c|c|c|}
\hline $\begin{array}{l}\text { Rye } \\
\text { Rye }\end{array}$ & $\begin{array}{l}\text { Acre } \\
\text { Ton }\end{array}$ & $\begin{array}{l}19.17 \\
65.78\end{array}$ & & & \\
\hline \multirow[t]{2}{*}{$\begin{array}{l}\text { Class I Land } \\
\text { Class II Land }\end{array}$} & $\begin{array}{l}\text { Acre } \\
\text { Acre }\end{array}$ & $\begin{array}{r}1.43 \\
17.74\end{array}$ & $\begin{array}{r}\$ 456.47 / \text { acre } \\
456.47 / \text { acre }\end{array}$ & & $\begin{array}{r}652.75 \\
8,097.78 \\
\end{array}$ \\
\hline & \multicolumn{3}{|c|}{ SILAGE OPERATING EXPENSE } & $\$$ & $8,750.53$ \\
\hline \multicolumn{6}{|l|}{ Pasture } \\
\hline Permanent cropland & Acre & 52.70 & & & \\
\hline $\begin{array}{l}\text { Class II Land } \\
\text { Class III land }\end{array}$ & $\begin{array}{l}\text { Acre } \\
\text { Acre }\end{array}$ & $\begin{array}{r}5.10 \\
47.60\end{array}$ & $\begin{array}{r}\$ 66.82 / \text { acre } \\
66.82 / \text { acre }\end{array}$ & $\$$ & $\begin{array}{r}340.78 \\
3,180.63\end{array}$ \\
\hline Permanent pastureland & Acre & 130.91 & & & \\
\hline $\begin{array}{l}\text { Class IV Land } \\
\text { Class VI Land } \\
\text { Class VII Land }\end{array}$ & $\begin{array}{l}\text { Acre } \\
\text { Acre } \\
\text { Acre }\end{array}$ & $\begin{array}{r}51.89 \\
9.04 \\
69.98\end{array}$ & $\begin{array}{r}66.82 / \text { acre } \\
66.82 / \text { acre } \\
6.66 / \text { acre }\end{array}$ & & $\begin{array}{r}3,467.29 \\
604.05 \\
466.07\end{array}$ \\
\hline \multicolumn{4}{|l|}{ ASTURE OPERATING E〉 } & $\$$ & $8,058.82$ \\
\hline
\end{tabular}

TOTAL LABOR, LIVESTOCK, AND CROP OPERATING CAPITAL REQUIRED 


\section{CAPITAL}

Interest on investment capital (land and buildings)

Interest on intermediate capital (machinery and livestock

Interest on operating capital (operating

expenses)

$\$$

$130,713.00$

$12.107 \%$

$15,825.42$

TOTAL ANNUAL INTEREST ON INVESTMENT, INTERMEDIATE AND OPERATING CAPITAL

TOTAL OPERATING CAPITAL REQUIRED

"Values marked by an asterisk were summed to obtain total initial capital investment and cost of first-year operations. ${ }^{\mathrm{a}}$ For explanation of labor procedure see footnote 26. 


\section{Capital}

Capital to cover the future costs of the silage- and pasture-only feeding system would require: investment capital-\$458,643.26 at an interest cost of $\$ 55,376.59$; intermediate capital- $\$ 130,713.00$ at an interest cost of $\$ 15,825.42$; and operating capital- $\$ 25,715.35$ at an interest cost of $\$ 3,113.36$. Future interest rates were estimated by inflating present rates by the 70.81 percent inflation rate.

Total minimum cost of the minimum resource requirements for the future silage- and pasture-only feeding system would be $\$ 689,386.98$. This amount includes initial investments and first-year operating costs, and therefore, represents the 1985 projected starting cost of the enterprise.

\section{Hay- and Pasture-Only Feeding System- Future Crop Yields and Input Prices}

The hay- and pasture-only feeding system had a minimum future cost estimated to be intermediate in capital requirements between the silage-only and silage-hay combination system. To acquire the initial resources and pay the first-year operational costs, it was estimated the total capital requirement would be $\$ 721,867.83$ (Table 5 ). The hay-only system would require $\$ 32,480.85$ more capital than the silage system, but $\$ 313.66$ less capital than the silagehay combination feeding system (Table 6). The main difference in the cost of the three systems is the amount of land necessary to support them. The silage system requires 476 acres; the hay system 520 acres; the silage-hay combination 490 acres. Although the combination system utilizes less land, the capital requirements for machinery to handle both silage and hay makes the machinery costs $\$ 24,338$ more than for the hay-only system.

The hay-only system was the most expensive of the three present-day systems but was intermediate in cost of the future systems. The primary reason for the exchange of positions of the hay and combination systems was the projected increase in yields of the crops. During the next 10 years it is projected silage yields will increase 50 percent while hay yields increase 57 to 63 percent (Appendix Table 4).

The average investment per cow replacement unit would be $\$ 7,218.77$ for the future hay-only feeding system.

\section{Land and Building Investment}

The future hay-only system would require 520.03 acres of total farm land at a value of $\$ 486,285.23$ or 67 percent of the total cost. Cropland would require 78.52 acres and pastureland would require 143.02 acres. Woodland and farmstead acquired would be 291.77 acres and 6.72 acres, respectively. The total capital required for the land and building investment would be $\$ 489,905.23$.

\section{Machinery and Livestock Investment}

It was assumed that the same 1,500-pound round bale hay production system would be used in the future hay system. The machinery complement value for this future feeding system, after adjusting for inflation, would be $\$ 69,445.00$. The capital investment needed for a 100-cow replacement unit herd would be $\$ 57,051.00$. The total amount of intermediate capital needed would be $\$ 126,496.00$. 
Table 5.

Minimum Resource Requirements for a 100 Beef Cow-Calf Herd, Winter Feed Supplied by Hay; Summer Feed Supplied by Pasture: Future (1985) Crop Yields and Input Prices

\begin{tabular}{|c|c|c|c|c|c|}
\hline Item & Unit & Amount & $\begin{array}{l}\text { Capital Type and } \\
\text { Rate per Unit }\end{array}$ & Value & \\
\hline & & & Investment & & \\
\hline \multicolumn{6}{|l|}{ LAND } \\
\hline Cropland (total) & Acre & 78.52 & $\$ 935.11 /$ acre & $\$ 73,424.83$ & \\
\hline $\begin{array}{l}\text { Class I } \\
\text { Class II } \\
\text { Class III }\end{array}$ & $\begin{array}{l}\text { Acre } \\
\text { Acre } \\
\text { Acre }\end{array}$ & $\begin{array}{r}1.56 \\
24.96 \\
52.00\end{array}$ & $\begin{array}{l}\$ 935.11 / \text { acre } \\
\$ 935.11 / \text { acre } \\
\$ 935.11 / \text { acre }\end{array}$ & $\begin{array}{r}1,458.77 \\
23,340.34 \\
48,625.72\end{array}$ & \\
\hline Pastureland (total) & Acre & 143.02 & $\$ 935.11 /$ acre & $133,739.42$ & \\
\hline $\begin{array}{l}\text { Class IV } \\
\text { Class VI } \\
\text { Class VII }\end{array}$ & $\begin{array}{l}\text { Acre } \\
\text { Acre } \\
\text { Acre }\end{array}$ & $\begin{array}{r}56.69 \\
9.88 \\
76.45\end{array}$ & $\begin{array}{l}\text { \$935.11/acre } \\
\$ 935.11 / \text { acre } \\
\$ 935.11 / \text { acre }\end{array}$ & $\begin{array}{r}53,011.39 \\
9,238.87 \\
71,489.16\end{array}$ & \\
\hline Woodland & Acre & 291.77 & $\$ 935.11 /$ acre & $272,837.04$ & \\
\hline Farmstead & Acre & 6.72 & $\$ 935.11 /$ acre & $6,283.94$ & \\
\hline TOTAL LAND & ACRES & 520.03 & & & $486,285.23$ \\
\hline \multirow[t]{2}{*}{ BUILDING SPACE } & $\mathrm{Sq} F \mathrm{Ft}$ & 500.00 & $7.24 / \mathrm{sq} \mathrm{ft}$ & & $3,620.00$ \\
\hline & \multicolumn{3}{|c|}{ TOTAL INVESTMENT CAPITAL REQUIRED } & & $\$ 489,905.23^{*}$ \\
\hline & \multicolumn{4}{|c|}{ Intermediate } & \\
\hline MACHINERY & Cow-mach unit & 100.00 & 649.45/unit & $\$ 69,445.00$ & \\
\hline \multirow[t]{2}{*}{ LIVESTOCK } & Cow-repl unit & 100.00 & $570.51 /$ unit & $\$ 57,051.00$ & \\
\hline & \multicolumn{3}{|c|}{ TOTAL INTERMEDIATE CAPITAL REQUIRED } & & $\$ 126,496.00^{*}$ \\
\hline
\end{tabular}


Table 5 Continued

\begin{tabular}{|c|c|c|c|c|}
\hline Item & Unit & Amount & $\begin{array}{l}\text { Capital Type and } \\
\text { Rate per Unit }\end{array}$ & Value \\
\hline
\end{tabular}

\section{LABOR}

Spring laboroperator's

\begin{tabular}{lr} 
Hour & 378.23 \\
Hour & 317.05 \\
Hour & 150.00 \\
Hour & 580.00 \\
\cline { 2 - 2 } Hour & $1,425.28$ \\
Hour & $1,040.00$ \\
Hour & 385.28 \\
\hline Hour & $1,425.28$ \\
\hline
\end{tabular}

LABOR $^{\mathrm{a}}$ operator's

Fall laboroperator's

Winter labor-

w operator's

TOTAL LABOR ${ }^{\mathrm{a}}$

Livestock labor

Crop labor

Operating Expenses

LIVESTOCK EXPENSE

Cow-repl unit

100.00

\$74.40/unit

$\$ 7,440.00$

CROP EXPENSE

HAY

Clover-Timothy

Acre

48.85

Clover-Timothy

Ton

170.56 
Alfalfa-Timothy Orchard

Acre

12.14

Alfalfa-Timothy

Orchard

Ton

44.55

TOTAL ESTABLISHMENT

COST IN YEAR 1
Acre

Acre

Acre

Acre
Class I Clover

Class II Clover

Class III

Clover

Alfalfa

1.56

24.96

22.33

12.14

ESTABLISHMENT COST CHARGED TO FIRST YEAR

Establishment cost
$\$ 216.93 /$ acre
Class I Clover

Acre

Class II Clover

Acre

1.56

24.96

Class III

Clover

Acre

22.33

Alfalfa

Acre

12.14

ESTABLISHMENT DISTRIBUTED OVER 5 YEARS

Pasture

Aftermath Hay

Acre

60.99

Permanent Cropland

Class III Land

Acre

17.54

143.02

Acre

Acre

Class IV Land

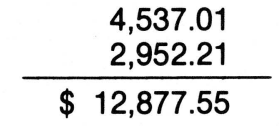

56.69
$\$ 216.93 /$ acre

$\$ 216.93 /$ acre

$\$ 287.17 /$ acre

$\$ 203.18 /$ acre

$\$ 203.18 /$ acre

$\$ 203.18 /$ acre

$\$ 243.18 /$ acre

338.41

$5,414.57$

$4,844.05$

$3,486.24$

$\$ 14,083.27$

\$ 316.96

$5,071.37$

\$ $12,877.55$

$\$ 1,172.02$

$\$ 66.82 /$ acre $\quad \$ 3,788.03$ 
Table 5 Continued

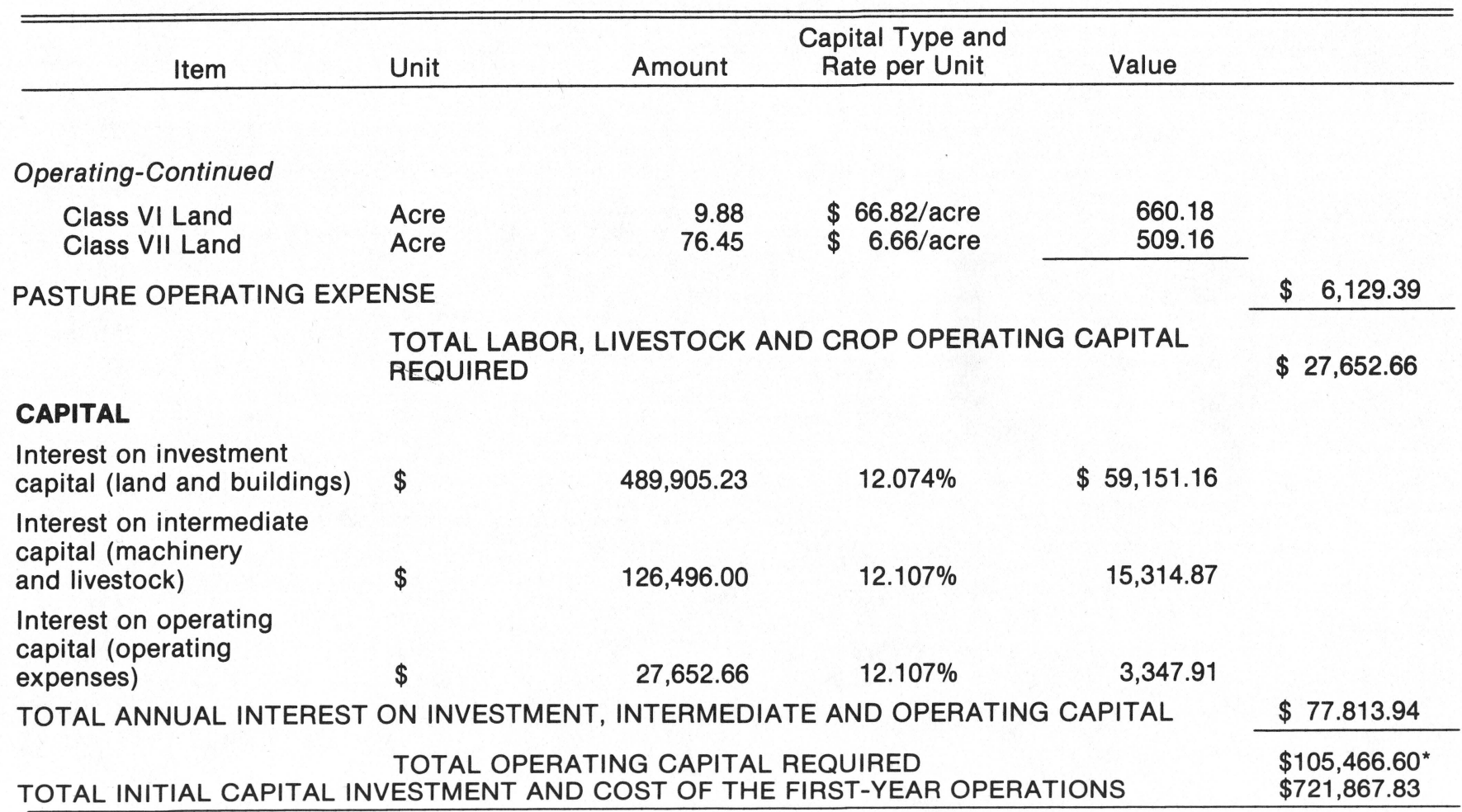

*Values marked by an asterisk were summed to obtain total initial capital investment and cost of first-year operations. ${ }^{2}$ For explanation of labor procedure see footnote 26. 
Table 6.

Minimum Resource Requirements for a 100 Beef Cow-Calf Herd, Winter Feed

Supplied by Silage and Hay; Summer Feed Supplied by Pasture: Future (1985) Crop Yields and Input Prices

\begin{tabular}{|c|c|c|c|c|c|}
\hline Item & Unit & Amount & $\begin{array}{l}\text { Capital Type and } \\
\text { Rate per Unit }\end{array}$ & Value & \\
\hline & & & Investment & & \\
\hline \multicolumn{6}{|l|}{ LAND } \\
\hline Cropland (Total) & Acre & 74.02 & $\$ 935.11 /$ acre & $\$ 69,216.84$ & \\
\hline $\begin{array}{l}\text { Class I } \\
\text { Class II } \\
\text { Class III }\end{array}$ & $\begin{array}{l}\text { Acre } \\
\text { Acre } \\
\text { Acre }\end{array}$ & $\begin{array}{r}1.47 \\
23.53 \\
49.02\end{array}$ & $\begin{array}{l}\$ 935.11 / \text { acre } \\
\$ 935.11 / \text { acre } \\
\$ 935.11 / \text { acre }\end{array}$ & $\begin{array}{r}1,374.61 \\
22,033.14 \\
45,839.09\end{array}$ & \\
\hline Pastureland (Total) & Acre & 134.80 & $\$ 935.11 /$ acre & $126,052.83$ & \\
\hline $\begin{array}{l}\text { Class IV } \\
\text { Class VI } \\
\text { Class VII }\end{array}$ & $\begin{array}{l}\text { Acre } \\
\text { Acre } \\
\text { Acre }\end{array}$ & $\begin{array}{r}53.43 \\
9.31 \\
72.06\end{array}$ & $\begin{array}{l}\$ 935.11 \text { /acre } \\
\$ 935.11 / \text { acre } \\
\$ 935.11 / \text { acre }\end{array}$ & $\begin{array}{r}49,962.93 \\
8,705.87 \\
67,384.03\end{array}$ & \\
\hline Woodland & Acre & 274.99 & $\$ 935.11 /$ acre & $257,145.90$ & \\
\hline Farmstead & Acre & 6.37 & $\$ 935.11 /$ acre & $5,956.65$ & \\
\hline TOTAL LAND & Acre & 490.18 & & & $\$ 458,372.22$ \\
\hline BUILDING SPACE & Sq ft. & 500.00 & $\$ 7.24 / \mathrm{sq} \mathrm{ft}$ & $3,620.00$ & \\
\hline Silo (Cement Trench) & Ton & 238.52 & $\$ 16.57 /$ ton & $3,952.28$ & \\
\hline \multirow[t]{2}{*}{ TOTAL BUILDING } & & & & & $7,572.28$ \\
\hline & \multicolumn{4}{|c|}{ TOTAL INVESTMENT CAPITAL REQUIRED } & $\$ 465,944.50$ \\
\hline
\end{tabular}


Table 6 Continued

\begin{tabular}{|c|c|c|c|c|c|}
\hline Item & Unit & Amount & $\begin{array}{l}\text { Capital Type and } \\
\text { Rate per Unit }\end{array}$ & Value & \\
\hline & \multicolumn{4}{|c|}{ Intermediate } & \multirow[b]{4}{*}{$\$ 150,834.00^{*}$} \\
\hline MACHINERY & Cow-mach unit & 100.00 & $\$ 937.83 /$ unit & $\$ 93,783.00$ & \\
\hline \multirow[t]{2}{*}{ LIVESTOCK } & Cow-repl unit & 100.00 & $\$ 570.51 /$ unit & $57,051.00$ & \\
\hline & \multicolumn{3}{|c|}{ TOTAL INTERMEDIATE CAPITAL REQUIRED } & & \\
\hline \multicolumn{6}{|l|}{ LABOR } \\
\hline $\begin{array}{c}\text { Spring labor- } \\
\text { operator's }\end{array}$ & Hour & 353.21 & & & \\
\hline $\begin{array}{l}\text { Summer labor- } \\
\text { operator's }\end{array}$ & Hour & 275.55 & & & \\
\hline $\begin{array}{l}\text { Fall labor- } \\
\text { operator's }\end{array}$ & Hour & 196.05 & & & \\
\hline $\begin{array}{l}\text { Winter labor- } \\
\text { operator's }\end{array}$ & Hour & $1,160.00$ & & & \\
\hline TOTAL LABOR ${ }^{a}$ & Hour & $1,986.81$ & & & \\
\hline Livestock labor & Hour & $1,620.00$ & & & \\
\hline Crop labor & Hour & 366.81 & & & \\
\hline $\begin{array}{l}\text { TOTAL PRODUCTIVE } \\
\text { LABOR: }\end{array}$ & Hour & $1,986.81$ & & & \\
\hline
\end{tabular}




\begin{tabular}{|c|c|c|c|c|c|}
\hline \multirow[b]{2}{*}{$\begin{array}{l}\text { LIVESTOCK EXPENSE } \\
\text { CROP EXPENSE }\end{array}$} & \multirow[b]{2}{*}{ Cow-repl unit } & \multicolumn{4}{|c|}{ Operating Expenses } \\
\hline & & 100.00 & $\$ 82.54 /$ unit & $\$$ & $8,254.00$ \\
\hline \multicolumn{6}{|l|}{ Silage } \\
\hline $\begin{array}{l}\text { Corn } \\
\text { Corn }\end{array}$ & $\begin{array}{l}\text { Acre } \\
\text { Ton }\end{array}$ & $\begin{array}{r}7.62 \\
212.24\end{array}$ & & & \\
\hline $\begin{array}{l}\text { Rye } \\
\text { Rye }\end{array}$ & $\begin{array}{l}\text { Acre } \\
\text { Ton }\end{array}$ & $\begin{array}{r}7.62 \\
26.28\end{array}$ & & & \\
\hline \multirow[t]{2}{*}{$\begin{array}{l}\text { Class I Land } \\
\text { Class II Land }\end{array}$} & $\begin{array}{l}\text { Acre } \\
\text { Acre }\end{array}$ & $\begin{array}{l}1.47 \\
6.15\end{array}$ & $\begin{array}{l}\$ 456.47 / \text { acre } \\
\$ 456.47 / \text { acre }\end{array}$ & & $\begin{array}{r}671.01 \\
2,807.29 \\
\end{array}$ \\
\hline & & & & $\$$ & $3,478.30$ \\
\hline \multicolumn{6}{|c|}{ SILAGE OPERATING EXPENSE } \\
\hline \multicolumn{6}{|c|}{$\begin{array}{l}\text { Hay } \\
\text { Alfalfa-Timothy }\end{array}$} \\
\hline $\begin{array}{l}\text { Alfalfa-Timothy } \\
\text { Orchard }\end{array}$ & Ton & 114.15 & & & \\
\hline \multicolumn{6}{|l|}{$\begin{array}{l}\text { Total Establishment } \\
\text { Cost in Year } 1\end{array}$} \\
\hline $\begin{array}{l}\text { Class II } \\
\text { Class III }\end{array}$ & $\begin{array}{l}\text { Acre } \\
\text { Acre }\end{array}$ & $\begin{array}{l}17.37 \\
13.07\end{array}$ & $\begin{array}{l}\$ 287.17 / \text { acre } \\
\$ 287.17 / \text { acre }\end{array}$ & $\$$ & $\begin{array}{l}4,988.14 \\
3,753.31 \\
\end{array}$ \\
\hline \multicolumn{4}{|c|}{ ESTABLISHMENT COST CHARGED TO FIRST YEAR } & $\$$ & $8,741.45$ \\
\hline \multicolumn{6}{|c|}{$\begin{array}{l}\text { Establishment cost } \\
\text { prorated over } 5 \text { years }\end{array}$} \\
\hline $\begin{array}{l}\text { Class II } \\
\text { Class III }\end{array}$ & $\begin{array}{l}\text { Acre } \\
\text { Acre }\end{array}$ & $\begin{array}{l}17.37 \\
13.07\end{array}$ & $\begin{array}{l}\$ 243.18 / \text { acre } \\
\$ 243.18 \text { acre }\end{array}$ & $\$$ & $\begin{array}{l}4,224.04 \\
3,178.36\end{array}$ \\
\hline \multicolumn{4}{|c|}{ ESTABLISHMENT DISTRIBUTED OVER 5 YEARS } & $\$$ & $7,402.40$ \\
\hline
\end{tabular}


Table 6 Continued

\begin{tabular}{|c|c|c|c|c|}
\hline Item & Unit & Amount & $\begin{array}{l}\text { Capital Type and } \\
\text { Rate per Unit }\end{array}$ & Value \\
\hline
\end{tabular}

Operating-Continued

\begin{tabular}{|c|c|c|c|c|c|}
\hline \multirow{2}{*}{$\begin{array}{l}\text { Pasture } \\
\text { Aftermath Hay } \\
\text { Permanent Cropland } \\
\text { Class III }\end{array}$} & Acre & 30.44 & & \multirow[b]{2}{*}{$\$$} & \multirow[b]{2}{*}{$2,402.18$} \\
\hline & Acre & 35.95 & \$ 66.82/acre & & \\
\hline Permanent Pastureland & Acre & 134.80 & & & \\
\hline $\begin{array}{l}\text { Class IV Land } \\
\text { Class VI Land } \\
\text { Class VII Land }\end{array}$ & $\begin{array}{l}\text { Acre } \\
\text { Acre } \\
\text { Acre }\end{array}$ & $\begin{array}{r}53.43 \\
9.31 \\
72.06\end{array}$ & $\begin{array}{c}\$ 66.82 / \text { acre } \\
\$ 66.82 / \text { acre } \\
\$ 6.66 / \text { acre }\end{array}$ & & $\begin{array}{r}3,570.19 \\
622.09 \\
479.92 \\
\end{array}$ \\
\hline \multicolumn{3}{|c|}{ PASTURE OPERATING EXPENSE } & & $\$$ & $7,074.38$ \\
\hline & \multicolumn{5}{|c|}{$\begin{array}{l}\text { TOTAL LABOR, LIVESTOCK AND CROP OPERATING CAPITAL } \\
\text { REQUIRED }\end{array}$} \\
\hline \multicolumn{6}{|l|}{ CAPITAL } \\
\hline $\begin{array}{l}\text { Interest on investment } \\
\text { capital (land and buildings) }\end{array}$ & $\$$ & $465,944.50$ & $12.074 \%$ & \multicolumn{2}{|c|}{$\$ 56,258.14$} \\
\hline $\begin{array}{l}\text { Interest on intermediate } \\
\text { capital (machinery } \\
\text { and livestock) }\end{array}$ & $\$$ & $150,834.00$ & $12.107 \%$ & & $18,261.47$ \\
\hline
\end{tabular}

Interest on investment capital (land and building and livestock) 
Interest on operating

capital (operating

expenses)

TOTAL ANNUAL INTEREST ON INVESTMENT, INTERMEDIATE AND OPERATING CAPITAL

*Values marked by an asterisk were summed to obtain total initial capital investment and cost of first-year operations.

${ }^{\mathrm{a}}$ For explanation of labor procedure see footnote 26 . 


\section{Labor Expense}

The available operator's labor would be sufficient to meet the labor requirements. Operator's labor of 378.23 hours would be required in spring when hay establishment costs are included in the first year. The spring season would require 339.84 hours of operator's labor if hay establishment costs are prorated over a five-year period. The labor requirements by use would be $1,040.00$ hours for livestock and 385.28 hours for crop production with hay establishment costs in year one. Crop production would require 346.89 hours if hay establishment costs are prorated.

\section{Livestock Expense}

The livestock expense associated with the future round bale feeding system would be $\$ 74.40$ per cow replacement (total herd cost of $\$ 7,440.00$ ).

\section{Crops}

A total of 60.99 acres of cropland would be utilized for hay production. All the Class I (1.56 acres) and Class II (24.96 acres) would be in clover-timothy hay. The Class III land would be divided, 22.33 acres in clover hay, and 12.14 acres in alfalfa-timothy-orchard grass mixture. The clover-timothy hay mixture provides a larger amount of aftermath pasture earlier than alfalfa, and when pasture is in short supply, thereby minimizing the amount of land that would need to be purchased for pasturing purposes alone.

Hay establishment cost would be $\$ 14,083.27$ in the initial year. This cost represents the lime and fertilizer needs to amend the soil conditions from their existing state. In future years only maintenance costs would be necessary. If the initital establishment costs were prorated over a five-year period, the annual costs would be reduced to $\$ 12,877.55$. A total of 170.56 tons of clover hay and 44.55 tons of alfalfa hay would be produced from the hay acreage.

Pasture production would require 143.02 acres of permanent pasture as follows: Class IV, 56.69; Class V, 9.88; and Class VII, 76.45 acres. The Class IV and VI pastures would be improved pasture and Class VII would be unimproved. The improvement of pastureland would be at a cost of $\$ 6,129.39$. In addition, 60.99 acres of aftermath pasture would be utilized.

\section{Capital}

Capital requirements for this feeding system would be: investment capital$\$ 489,905.23$ at an interest cost of $\$ 59,151.16$; intermediate capital$\$ 126,496.00$ at an interest cost of $\$ 15,314.87$; operating capital $-\$ 27,652.66$ at an interest cost of $\$ 3,347.91$ when hay establishment costs are included in year one.

The total least cost of the future minimum resource requirements when feeding hay and pasture only would be $\$ 721,867.83$. Hay establishment costs and other first-year expenses are included in this total. Therefore, the total minimum cost represents the starting cost of this future system.

\section{Sllage, Hay and Pasture Feeding System- Future Crop Yields and Input Prices}

The minimum resource requirements at least cost for a future combination silage and hay winter-feeding system are shown in Table 6 . The combination feeding system would have the highest minimum cost of the three systems, $\$ 722,181.49, \$ 32,794.51$ higher than the future silage system but only $\$ 313.66$ 
higher than the future hay-only system. For a 100-cow replacement unit herd, average investment per unit would be $\$ 7,221.81$.

\section{Land and Building Investment}

The total land requirement for the future combination system would be 490.18 acres at a value of $\$ 458,372.22$ (63 percent of the total cost). 74.02 Acres of cropland and 134.80 acres of pastureland would be required. The acreage of woodland and farmstead which would be acquired with the other land would be 274.99 acres and 6.37 acres respectively. The total capital required for the land and building investment would be $\$ 465,944.50$ which includes $\$ 3,952.28$ for a 238-ton capacity cement trench silo. Hay establishment costs would not affect the labor requirements of the other seasons. Livestock will require $1,620.00$ hours of labor and crop production will require 366.81 hours with hay establishment costs in year one. By prorating hay establishment costs, crop production would require 346.43 hours of labor.

\section{Livestock Expense}

The items contributing to livestock expenses would not be different in the future than those in the present combination feeding system; the value of livestock expenses would be inflated from present cost to give a future cost of $\$ 82.54$ per cow replacement unit, or $\$ 8,254.00$ for the herd.

\section{Crops}

The winter feed needs of the beef herd would require the production of 7.62 acres of silage when using the future combination system. Corn would supply 212.24 tons of silage and the rye cover crop would produce 26.28 tons. It would be necessary to utilize 1.47 acres of Class I land and 6.15 acres of Class II land to produce the required silage. Operating cost of silage production would be $\$ 3,478.30$.

Alfalfa-grass hay would be selected to meet the hay portion of the feed requirements. All hay production would be on 30.44 acres of Class II and III land at an operating cost of $\$ 8,741.45$ with establishment cost in year one. The cost of hay production would be $\$ 7,402.40$ when prorating establishment costs. The required acreage would produce 114.15 tons of alfalfa-grass hay.

Pasture production would require a total of 170.75 acres to meet spring, summer, and fall feed requirements with the future combination system. Aftermath pasture from the 30.44 acres of hayland would be included in this total. Cropland (Class III) would provide 35.95 acres of permanent pasture and pastureland would provide 134.80 acres. Pasture production would have an operating cost of $\$ 7,074.38$ for the six-month grazing season. Pasture costs include initial improvement costs for Classes IV and VI land.

\section{Capital}

Capital for the combination hay-silage feeding system would require: investment capital $-\$ 465,944.50$ at an interest cost of $\$ 56,258.14$; intermediate capital- $\$ 150,834.00$ at an interest cost of $\$ 18,261.47$; operating capital$\$ 27,548.13$ at an interest cost of $\$ 3,335.25$ when including hay establishment costs in year one.

The total minimum cost of the minimum resource requirements for a future combination silage and hay feeding system would be $\$ 722,181.49$. First-year costs, such as hay establishment and asset investments, are included in this 
total as they were in the totals of all other results. Therefore, this total minimum cost would represent the starting cost for the 100-cow-calf herd when using the future combination feeding system.

Since the cost of the combination feeding system of hay and silage is so near the cost of the hay-only feeding system a beef producer might give serious thought to which of these two systems to select. On one hand, the hay-only system has a larger land investment but a smaller machinery investment. On the other hand, the combination system has a smaller land and building investment, which includes a 238-ton trench silo, but a larger machinery investment to plant and harvest two kinds of crops.

\section{Machinery and Livestock Investment}

The machinery complement for the future combination feeding system would not be changed from that of the present system (Appendix Table 16). Inflation of the machinery value was required in the analysis and resulted in a future value of $\$ 93,783.00$. The capital investment needed to acquire a $100-$ cow replacement unit herd would be $\$ 57,051.00$. The total amount of intermediate capital needed would be $\$ 150,834.00$.

\section{Labor Expense}

The operator's labor would be sufficient to meet the labor requirements of all seasons; no additional labor would be needed. The spring season would require 353.21 hours of operator's labor when hay establishment costs are included in the first year.

\section{Resume of Programming Results}

A comparison of investments, operating expenses and total beginning costs of each alternative system discussed is found in Table 7 . The investment in land makes up about 75 percent of the total cost required to begin a 100 beef cowcalf operation at the present time. Machinery and livestock expenses constitute approximately 15 percent of the total, operating expenses for labor, livestock and crops 3.5 percent, and interest on invested capital 6.5 percent. By 1985 , with a projected inflation rate of 70.8 percent, the total investment required will increase by approximately 30 percent. Due to increased crop yields expected by that time, the investment in land is estimated to drop to 66 percent of the total investment. Machinery and livestock expenses follow at nearly 20 percent; labor, livestock and crops 3.8 percent; and interest 10.8 percent.

\section{Effect of Land Costs on the Total Investment Requirement}

Land costs represent such a large proportion of the total investment cost to begin and operate a 100-cow beef herd that a change in land prices can affect the total investment required substantially. To illustrate the effect land prices of $\$ 250.00$ and $\$ 400.00$ per acre would have on total investment, these were compared to the price of land used in the program analysis, $\$ 547.15$ per acre (Table 8). The total cost of all non-land items was less than 50 percent of the investment required for all three feeding systems even at the cheapest land price of $\$ 250.00$ per acre. As the land price increased to $\$ 547.15$ the non-land items became a relative smaller percentage of the total cost (approximately 20 percent). 
Table 7.

Summary of Investments, Operating Expenses and Total Beginning Costs of the Minimum Resource Requirements for Three Alternative Feeding SystemsPresent and Future

\begin{tabular}{|c|c|c|c|c|c|}
\hline $\begin{array}{l}\text { Feeding } \\
\text { System }\end{array}$ & $\begin{array}{l}\text { Land and } \\
\text { Buildings } \\
\text { Investment }\end{array}$ & $\begin{array}{c}\text { Machinery } \\
\text { and } \\
\text { Livestock } \\
\text { Investment }\end{array}$ & $\begin{array}{c}\text { Labor, } \\
\text { Livestock, } \\
\text { and Crop } \\
\text { Operating } \\
\text { Expenses }\end{array}$ & $\begin{array}{c}\text { Interest } \\
\text { on } \\
\text { Capital } \\
\text { Operating } \\
\text { Expenses }\end{array}$ & $\begin{array}{l}\text { Total } \\
\text { Minimum } \\
\text { Cost }\end{array}$ \\
\hline $\begin{array}{l}\text { PRESENT-1 } \\
\text { Silage and } \\
\text { pasture only }\end{array}$ & $\$ 398,830.90$ & $\$ 76,525.00$ & $\$ 16,518.22$ & $\$ 34,790.12$ & $\$ 526,664.24$ \\
\hline $\begin{array}{l}\text { Silage, hay } \\
\text { and pasture }\end{array}$ & $410,244.47$ & $88,305.00$ & $18,920.53$ & $36,602.47$ & $554,072.47$ \\
\hline $\begin{array}{l}\text { Hay and } \\
\text { pasture only }\end{array}$ & $441,596.44$ & $74,056.00$ & $19,860.74$ & $37,875.15$ & $573,388.33$ \\
\hline $\begin{array}{l}\text { FUTURE-19 } \\
\text { Silage and } \\
\text { pasture only }\end{array}$ & $458,643.26$ & $130,713.00$ & $25,715.35$ & $74,315.37$ & $689,386.98$ \\
\hline $\begin{array}{l}\text { Hay and } \\
\text { pasture only }\end{array}$ & $489,905.23$ & $126,496.00$ & $27,652.66$ & $77,813.94$ & $721,867.83$ \\
\hline $\begin{array}{l}\text { Silage, hay } \\
\text { and Pasture }\end{array}$ & $465,944.50$ & $150,834.00$ & $27,548.13$ & $77,854.86$ & $722,181.49$ \\
\hline
\end{tabular}


Table 8.

Minimum Total Investment Cost for a 100 Beef CowCalf Herd with Varying Land Costs, Three Alternative Feeding Systems, Present Conditions

\begin{tabular}{lrrrr}
\hline \hline $\begin{array}{l}\text { Type of } \\
\text { Feeding } \\
\text { System }\end{array}$ & $\begin{array}{c}\text { Total of All } \\
\text { Non-land } \\
\text { Costs }\end{array}$ & \multicolumn{3}{c}{$\begin{array}{c}\text { Total Costs, with } \\
\text { Varying Cost per Acre } \\
\text { for Land }\end{array}$} \\
\hline Silage & $\$ 108,106.78$ & $\$ 229,246.36$ & $\$ 413,930.11$ & $\$ 526,664.24$ \\
Silage-Hay & $119,941.02$ & $318,192.67$ & $437,143.65$ & $554,072.47$ \\
Hay & $102,845.30$ & $317,724.02$ & $446,652.43$ & $573,328.33$ \\
\hline
\end{tabular}

It is possible to examine any land price by multiplying the land cost per acre by one plus the interest rate for investment capital and then multiplying this product times the acres of land required for any of the three alternative feeding systems. To illustrate this process assume the land price to be $\$ 250.00$ per acre, an interest rate of 7.069 percent and the acreage needed for the all-silage feeding system, present conditions, to be 714.08 acres (Table 1). Proceed as follows:

$$
\begin{aligned}
& \$ 250.00 \times 1.07069=\$ 267.6725 \\
& \$ 267.6725 \times 714.08=\$ 191,139.58
\end{aligned}
$$

The $\$ 191,139.58$ is the cost of land plus the interest for a year. Adding the land cost, plus the non-land cost found in Table $8, \$ 108,106.78$, gives the total for $\$ 250.00$ land of $\$ 229,246.36$ (Table 8). The reader must be aware that the total cost provided by this method or the total costs found throughout the analysis do not apply everywhere. These costs apply only to the conditions examined among which are: land class distribution percentage from the Leading Creek Valley of Randolph County, soil fertility conditions described, fertilization rates used, and interest rate selected.

\section{SUMMARY}

Using present crop yields and input prices the results of this study indicated that of the three alternative feeding systems considered, the silage- and pasture-only system had the lowest minimum cost and would also have the lowest minimum cost when using estimated 1985 crop yields and input prices. The hay- and pasture-only system had the highest minimum cost when using present data and would have an intermediate minimum cost when using future data. The combination feeding system had an intermediate minimum cost under present production conditions and would have the highest minimum cost under estimated future conditions. 
The results showed a $\$ 46,756.05$ cost difference between the silage-only and the hay-only systems using present production-price data. A $\$ 27,440.19$ cost difference was shown between the silage-only and the combination systems. Thus, a substantial cost reduction could be made by employing the silage-only feeding system rather than either of the other two systems. The silage feeding system holds an advantage in cost over the other two systems through the much smaller acreage of cropland required to produce the winter feed supply. In choosing between the combination feeding system and hay only, the higher forage yields obtained from silage production, and as a consequence a smaller acreage of cropland is needed, favors the combination system at the present time. A feeding system including silage also may have an advantage by being less subject to the effects of harvest weather conditions.

When using estimated future (1985) data, the results showed a $\$ 32,480.87$ cost difference between the silage-only and the hay-only systems. A $\$ 32,794.51$ cost difference would occur between the silage-only and the combination systems. The cost difference that would occur between the hayonly and the combination systems would only be $\$ 313.66$, the combination being higher when using future data. As when using present crop yields and input prices, a substantial cost reduction could be obtained by choosing the silage-only system over the other two systems. The cost difference would not be great between the hay-only and the combination systems. The improved position of the hay-only feeding system as compared to a combination feeding system is the result of expected improvement in hay yields relative to expected improvement in silage yields.

It is emphasized that the results of this study are applicable to a limited area and to land characteristics of the Leading Creek Valley of Randolph County, West Virginia. Also, the study results showed the acquisition of a large quantity of woodland. Whenever crop and pastureland could be obtained without acquiring such a large acreage of woodland, total cost of each feeding system would probably be less.

\section{Bibliography}

Agricultural Planning Data for the Northeastern United States. Department of Agricultural Economics and Rural Sociology, A.E. \& R.S. 51. University Park: The Pennsylvania State University, 1965.

"A Plan for Integrating the Operations of West Virginia's Institutional Farms." College of Agriculture and Forestry. Morgantown: West Virginia University, October, 1975.

Arsdall, Roy N. "Resource Requirements, Investments, Costs, and Expected Returns from Selected Beef-Feeding and Beef-Raising Enterprises." Illinois Agricultural Exp. Sta. Study Ae-4075. Urbana: U. Illinois, 1965. (Mimeographed.)

Atkinson, Ronald C. "Minimum Land Requirements for a \$5,000 Farm Income in the Brown Soil Area of West Tennessee." Unpublished Master's Thesis, U. Tenn., 1966. 
Baker, Barton. Personal interviews with him as an agronomist, Allegheny Highlands Project, West Virginia, November, 1975 through March, 1976.

Barnhill, Harold E. Resource Requirements on Farms for Specified Operator Incomes, USDA, Agricultural Economic Report No. 5. Washington, D.C.: U.S. Government Printing Office, revised, 1964.

Barr, Alfred L. Beef Cattle Production: Cost and Returns for the Cow-Calf System in West Virginia, West Virginia University Agricultural Experiment Station Bulletin 527. Morgantown: West Virginia University, 1966, reprinted, 1969.

Barr, Alfred L., Toben, George E., and Wilson, Charles C., Jr. Resources, Production and Income on Eastern West Virginia Beef Cattle Farms, West Virginia Agricultural Experiment Station Bulletin 546. Morgantown: West Virginia University, 1967, reprinted, 1969.

Costs and Returns Guide for Crops in Virginia. Extension Division Publication 607. Blacksburg: Virginia Polytechnic Institute and State University, revised June, 1974.

Davis, Velmar W. "Minimum Resources for Specified Incomes on Corn Farms and Hog Farms," Illinois Agricultural Economics, University of Illinois Agricultural Experiment Station Publication, Vol. 4 No. 1. Urbana: University of Illinois, 1964.

Eagan, Gerald V. Personal interviews with him as an agricultural economist, Division of Resource Management, West Virginia University, Morgantown, West Virginia, January through July, 1976.

"Estimated Average Acre Yield of Principal Crops." West Virginia Technical Guide LRA-126, Section II-D. Morgantown: Soil Conservation Service, February, 1970.

“Fertilizer Recommendations for Silage Corn." West Virginia University Soil Testing Laboratory Sheet Cs. Morgantown: West Virginia University, May, 1973.

"Fertilizer Recommendations for Topdressing Legume-Tall Grass Hay or Pasture (over 30\% Legume)," West Virginia University Soil Testing Laboratory Sheet MI. Morgantown: West Virginia University, May, 1973.

"Fertilizer Recommendations for Topdressing Tall Grass Hay or Pasture (under 30\% Legumes)." West Virginia University Soil Testing Laboratory Sheet M. Morgantown: West Virginia University, May, 1973.

Huddleston, John S. "Minimum Resource Requirements and Related Optimum Enterprise Combinations for Specified Income Levels for the CashGrain Area of Northeastern Virginia." Unpublished Master's Thesis, Virginia Polytechnic Institute, 1966.

Hulver, Donald M. "Total Digestible Nutrient Requirements for Beef Cattle During Growth, Gestation, and Lactation." Unpublished Master's Thesis, West Virginia University, 1976.

Layton, Ronald A., Barr, Alfred L., and Nesselroad, Paul E. Estimated Annual Costs, Production and Income for Selected Livestock and Crop Enterprises, 
Eastern West Virginia, West Virginia University Agricultural Experiment Station Bulletin 594T. Morgantown: West Virginia University, 1970.

Nutrient Requirements of Beef Cattle. Sub-committee on Beef Cattle Nutrition, National Research Council, Fourth Revised Edition. Washington, D.C.: National Academy of Sciences, 1970.

Sharpe, George. Land Judging-Learning to Know Your Soil, West Virginia University Cooperative Extension Service Circular 406R. Morgantown: West Virginia University.

Silage and Silos. Pennsylvania State University College of Agriculture Extension Service Special Circular 80. University Park: The Pennsylvania State University.

Sperow, Charles B., Jr. Personal interviews with him as an agronomist, Division of Plant Sciences, West Virginia University, Morgantown, West Virginia, March through April, 1976.

Toben, George E. "Farm Plans of the Allegheny Highlands Project." Unpublished Farm Plans, West Virginia University Agricultural Experiment Station. Morgantown: West Virginia University.

Personal interviews with him as an agricultural economist and farm management specialist, Division of Resource Management, West Virginia University, Morgantown, West Virginia, January through August, 1976.

Trent, Roy E., Weedfall, Robert O., and Dickerson, W. H. West Virginia University Climate in Relation to Weather Sensitive Industry, West Virginia University Agricultural Experiment Station Bulletin 591T. Morgantown: West Virginia University, 1970.

U.S. Department of Agriculture, Economic Research Service. Farm Real Estate Market Development. Bulletin CD-80. Washington: U.S. Government Printing Office, February, 1976.

U.S. Department of Agriculture, Statistical Reporting Service. Agricultural Prices. Crop Reporting Board. Washington, D.C.: U.S. Government Printing Office, January, 1975 through January, 1976.

Office, 1975.

Agricultural Statistics. Washington, D.C.: U.S.Government Printing

U.S. Geological Survey. A map showing the elevation of the Elkins, West Virginia area. Washington, D.C.: U.S. Government Printing Office, 1969.

U.S. Senate, Sub-committee on Labor. Fair Labor Standards Amendments of 1974, P.L. 93-259. Washington, D.C.: U.S. Government Printing Office, April, 1974.

Wamsley, Benjamin W., Jr. Personal interview with him as an extension specialist in animal and veterinary science, Division of Animal and Veterinary Sciences, West Virginia University, Morgantown, West Virginia, 1976.

West Virginia State Tax Department. Taxes Levied on Classified Assessed Valuations, Richard L. Dailey. LGR 12:54, Charleston: 1975. 
Blank Page in Original Bulletin 


\section{APPENDIX}

Appendix Table 1.

Distribution by Acres and Percentages of the Land by Capability Class and Use on the Five Study

Farms $^{\mathrm{a}}$

\begin{tabular}{lrrrrr}
\hline \hline & \multicolumn{5}{c}{ Farm } \\
\cline { 2 - 6 } Class or Use & \multicolumn{1}{c}{ I } & \multicolumn{1}{c}{ II } & \multicolumn{1}{c}{ III } & \multicolumn{1}{c}{ IV } & \multicolumn{1}{c}{ V } \\
\hline & & & & \\
Land Class I & 6.00 & 0.00 & 0.00 & 0.00 & 0.00 \\
Land Class II & 7.30 & 39.70 & 29.20 & 3.00 & 8.00 \\
Land Class III & 68.70 & 40.70 & 54.60 & 13.40 & 5.00 \\
Cropland $^{\mathrm{b}}$ & 34.70 & 36.90 & 102.80 & 83.90 & 36.50 \\
Land Class IV $_{\text {Land Class VI }}$ & 10.60 & 13.10 & 51.70 & 88.60 & 34.80 \\
Land Class VII & 12.00 & 11.10 & 11.00 & 0.00 & 0.00 \\
Pastureland $^{\mathrm{b}}$ & 15.90 & 9.00 & 105.90 & 45.40 & 91.60 \\
Woodland & 86.10 & 72.60 & 149.60 & 66.30 & 95.10 \\
Farmstead $^{\text {Total }}$ & 777.00 & 45.00 & 0.00 & 69.00 & 129.00 \\
& 2.00 & 1.00 & 6.00 & 9.00 & 4.00 \\
& 899.80 & 155.50 & 258.40 & 228.20 & 264.60 \\
\hline
\end{tabular}

(continued) 


\section{Appendix Table 1 Continued}

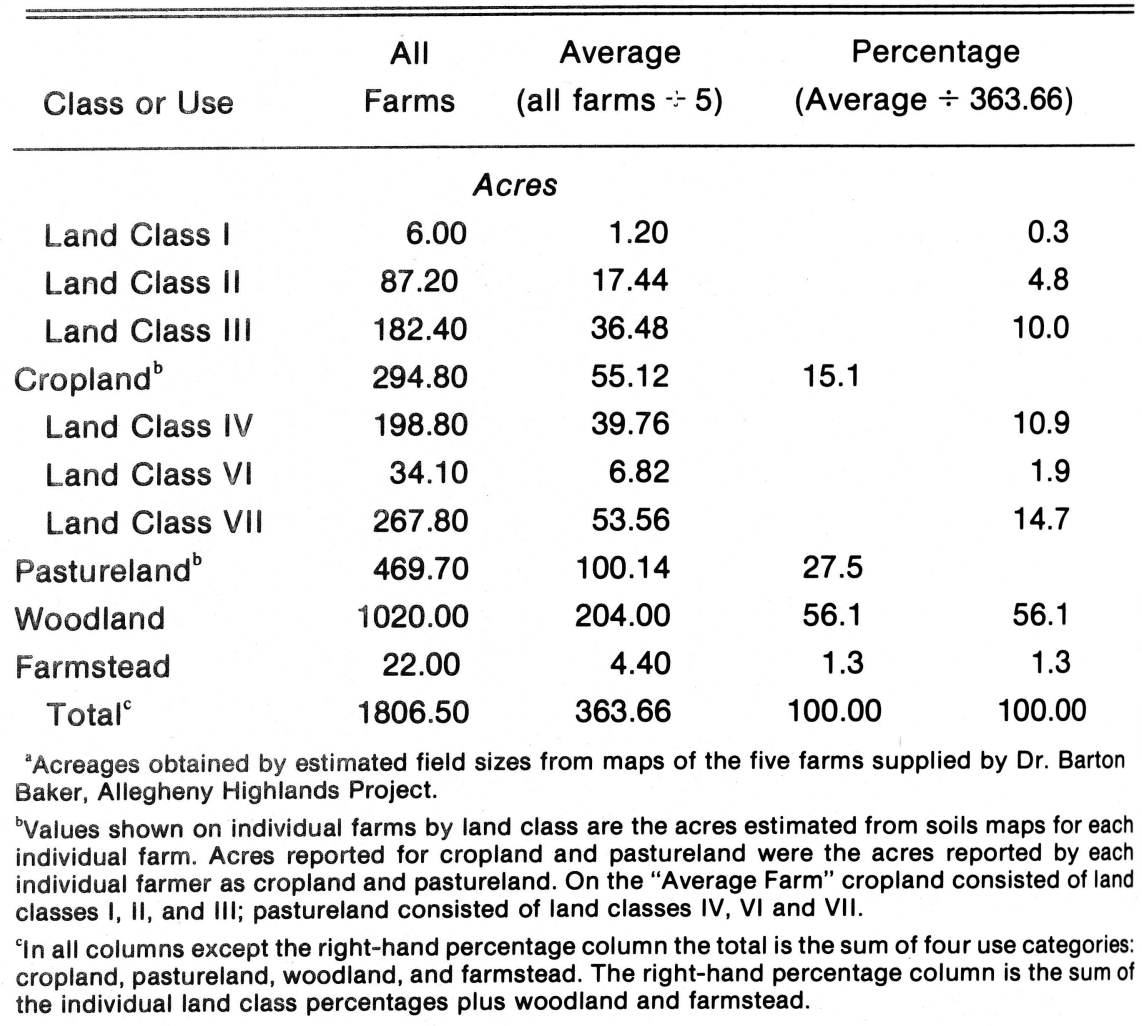




\section{Appendix Table 2.}

Silage-Estimated Annual Costs Per Acre Producing Corn and A Rye Cover Crop as Silage-Present Costs for Present Yields ${ }^{a}$

\begin{tabular}{|c|c|c|c|c|c|c|c|c|}
\hline & \multicolumn{3}{|c|}{ Tractor $^{\mathrm{b}}$} & \multicolumn{2}{|c|}{ Machinery $^{\mathrm{b}}$} & \multirow{3}{*}{$\begin{array}{l}\text { Total } \\
\text { Cost }\end{array}$} & \multicolumn{2}{|c|}{ Labor } \\
\hline Times & \multirow[b]{2}{*}{ Hrs. } & \multirow[b]{2}{*}{ Size } & Cost & \multicolumn{2}{|r|}{ Cost } & & \multirow[t]{2}{*}{ Hrs. } & \multirow[t]{2}{*}{ Season } \\
\hline & & & Variable Fixed & Hrs. & $\overline{\text { Variable Fixed }}$ & & & \\
\hline
\end{tabular}

\section{Operation}

Spread fertilizer

Plow, 3-14 in.

Disc

Harrow

Plant (with fertilizer)

2-row

o Spray (pre-emerge)

Spray (post-emerge)

Cut-1-row forage

harvester

Haul-2 wagons

Pack silage

Disc

Sow cover croprye \& timothy

Cut-cover crop

Haul-2 wagons

Pack silage

\begin{tabular}{lrlrrr} 
& & & \multicolumn{3}{c}{ Custom } \\
1 & 0.80 & $50 \mathrm{hp}$ & $\$ 0.96$ & $\$ 1.76$ & 0.80 \\
2 & 0.47 & $50 \mathrm{hp}$ & 0.56 & 1.03 & 0.47 \\
1 & 0.20 & $35 \mathrm{hp}$ & 0.17 & 0.32 & 0.20 \\
& & & & & \\
1 & 0.40 & $50 \mathrm{hp}$ & 0.48 & 0.88 & 0.40 \\
1 & 0.10 & $35 \mathrm{hp}$ & 0.09 & 0.16 & 0.10 \\
.33 & 0.03 & $35 \mathrm{hp}$ & 0.03 & 0.05 & 0.03 \\
& & & & & \\
1 & 1.50 & $50 \mathrm{hp}$ & 1.80 & 3.30 & 1.50 \\
& 1.50 & $35 \mathrm{hp}$ & 1.28 & 2.40 & 3.00 \\
& 1.50 & $50 \mathrm{hp}$ & 1.80 & 3.30 & \\
1 & 0.23 & $50 \mathrm{hp}$ & 0.28 & 0.51 & 0.23 \\
& & & & & \\
1 & 0.30 & $50 \mathrm{hp}$ & 0.36 & 0.66 & 0.30 \\
1 & 1.00 & $50 \mathrm{hp}$ & 1.20 & 2.20 & 1.00 \\
& 1.50 & $35 \mathrm{hp}$ & 1.28 & 2.40 & 3.00 \\
& 1.50 & $50 \mathrm{hp}$ & 1.80 & 3.30 &
\end{tabular}

\begin{tabular}{crrrl}
$\$ 0.78$ & $\$ 1.04$ & $\$ 4.54$ & 0.90 & Spring \\
0.80 & 2.63 & 5.02 & 0.48 & Spring \\
0.02 & 0.26 & 0.77 & 0.25 & Spring \\
& & & & \\
0.10 & 0.54 & $2.10^{\mathrm{d}}$ & 0.80 & Spring \\
0.03 & 0.21 & 0.49 & 0.20 & Spring \\
0.01 & 0.06 & 0.15 & 0.06 & Spring \\
& & & & \\
1.88 & 7.43 & 14.41 & 1.80 & Fall \\
3.15 & 5.10 & 11.93 & 1.80 & Fall \\
& & 5.10 & 1.80 & Fall \\
0.39 & 1.29 & 2.47 & 0.24 & Fall \\
& & & & \\
0.32 & 1.20 & 2.54 & 0.40 & Fall \\
1.25 & 4.95 & 9.60 & 1.40 & Spring \\
3.15 & 5.10 & 11.93 & 1.80 & Spring \\
& & 5.10 & 1.80 & Spring \\
\cline { 3 - 4 } & & $\$ 78.15$ & 13.73 &
\end{tabular}




\section{Appendix Table 2 Continued}

\begin{tabular}{|c|c|c|c|}
\hline Materials and Seeds ${ }^{e}$ & Prices per Unit ${ }^{\mathrm{f}}$ & Application Rate & Cost \\
\hline $\begin{array}{c}\text { Fertilizer }^{\mathrm{g}} 10-10-10^{\mathrm{h}} \\
\mathrm{K}_{2} 0-60 \% \\
.00 / \text { ton (MP) }\end{array}$ & $\begin{array}{l}\$ 136.00 / \text { ton } \\
\text { MP, } 100 \mathrm{lb} / \text { acre }\end{array}$ & $10-10-10,1250 \mathrm{lb} /$ acre & $\$ 85.00$ \\
\hline Lime (custom applied) & $\$ 10.00 /$ ton & $1000 \mathrm{lb} / \mathrm{acre}(2 \mathrm{~T} / \mathrm{acre}$ each $4 \mathrm{yr})$ & 5.00 \\
\hline $\begin{array}{l}\text { Seeds } \\
\text { Corn } \\
\text { Rye } \\
\text { Timothy }\end{array}$ & $\begin{array}{lc}\$ & 36.80 / \mathrm{bu} \\
\$ & 5.90 / \mathrm{bu} \\
\$ & 43.00 / 100 \mathrm{lb}\end{array}$ & $\begin{array}{l}25 \mathrm{lb} / \text { acre } \\
2 \mathrm{bu} / \text { acre } \\
7.5 \mathrm{lb} / \text { acre }^{\mathrm{i}}\end{array}$ & $\begin{array}{r}16.43 \\
11.80 \\
3.23\end{array}$ \\
\hline $\begin{array}{l}\text { Sprays } \\
\text { Atrazine } \\
\text { Simazine } \\
\text { 2,4-D }\end{array}$ & $\begin{array}{l}\$ 15.70 / 5 \mathrm{lb} \\
\$ 15.70 / 5 \mathrm{lb} \\
\$ 10.85 / \mathrm{gal}\end{array}$ & $\begin{array}{l}1.5 \mathrm{lb} / \text { acre } \\
1.5 \mathrm{lb} / \text { acre } \\
0.5 \mathrm{gal} / \text { acre }\end{array}$ & $\begin{array}{l}4.71 \\
4.71 \\
5.43\end{array}$ \\
\hline \multirow[t]{2}{*}{ Land taxes $^{\mathrm{j}}$} & & & 2.10 \\
\hline & & Total Annual Cost per Acre & $\$ 222.36^{k}$ \\
\hline \multicolumn{2}{|c|}{$\begin{array}{l}\text { Yields by land class and adjustments in yields to account for harvesting } \\
\text { and feeding losses are given in Appendix Table } 4 .\end{array}$} & \multicolumn{2}{|l|}{ 'Prices obtained from: } \\
\hline \multicolumn{2}{|c|}{$\begin{array}{l}\text { 'Tractor and machinery hours, sizes, and costs were taken from Costs and } \\
\text { Returns Guide for Crops in Virginia, Extension Division Publication } 607 \\
\text { (Blacksburg: Virginia Polytechnic Institute and State University, revised } \\
\text { June, 1974), Table B, p. } 11 \text { and Table A, pp. 69-71. }\end{array}$} & \multicolumn{2}{|c|}{$\begin{array}{l}\text { Fertilizer-USDA, Agricultural Prices, Statistical Reporting Service, } \\
\text { Crop Reporting Board PR } 1 \quad(10-75) \text { (Washington, D.C.: U.S. } \\
\text { Government Printing Office, October, 1975), pp. 23-25. }\end{array}$} \\
\hline \multicolumn{2}{|c|}{ 'No allowance was made for cost differences between land classes. } & \multicolumn{2}{|c|}{ Grass Seed-Agricultural Prices, op. cit., September, 1975, p. 22.} \\
\hline \multicolumn{2}{|c|}{ Includes $\$ 0.10$ for truck cost. } & \multicolumn{2}{|c|}{$\begin{array}{l}\text { Lime-Agricultural Stabilization and Conservation Service, Elkins, W. } \\
\text { Va., February, } 1976 \text { (telephone). }\end{array}$} \\
\hline \multicolumn{2}{|c|}{$\begin{array}{l}\text { "Taken from "A Plan for Integrating the Operations of West Virginia's } \\
\text { Institutional Farms," College of Agriculture and Forestry (Morgantown: } \\
\text { West Virginia University, October, 1975). }\end{array}$} & $\begin{array}{l}\text { Sprays-Southern States Cooperative S } \\
\text { February, } 1976 \text { (telephone) }\end{array}$ & ervice, Elkins, W.Va., \\
\hline
\end{tabular}


8"Fertilizer Recommendations for Silage Corn," West Virginia University Soil Testing Laboratory Sheet C5 (Morgantown: West Virginia University, May, 1973)

${ }^{\mathrm{h}} 10-10-10$ fertilizer supplies all nitrogen and phosphate $\left(\mathrm{P}_{2} \mathrm{O}_{5}\right)$ and a portion of the potash $\left(\mathrm{K}_{2} \mathrm{O}\right)$. The remaining $\mathrm{K}_{2} \mathrm{O}$ is supplied by $60 \%$ muriate of potash. $1,000 \mathrm{lb} / \mathrm{ac}$ of $10-10-10$ is applied before plowing and $250 \mathrm{lb} / \mathrm{ac}$ is applied with planter. $100 \mathrm{lb} / \mathrm{ac}$ of muriate potash is applied before plowing.
$5 \mathrm{lb} / \mathrm{ac}$ when sown on ground with possibility of going into alfalfa. $10 \mathrm{lb}$./ac when sown on ground with possibility of going into clover. Price used is an average of $\$ 3.23 /$ ac.

'West Virginia State Tax Department, Taxes Levied on Classified Assessed Valuations, Richard L. Dailey, LGR12:54 (Charleston: 1975 tax year).

${ }^{\mathrm{k}}$ Total cost does not include a charge for labor or land other than land taxes. 


\section{Appendix Table 3}

Silage-Estimated Annual Costs Per Acre Utilizing Corn and a Rye Cover Crop as Silage-Future Cost for Future Yields ${ }^{a}$

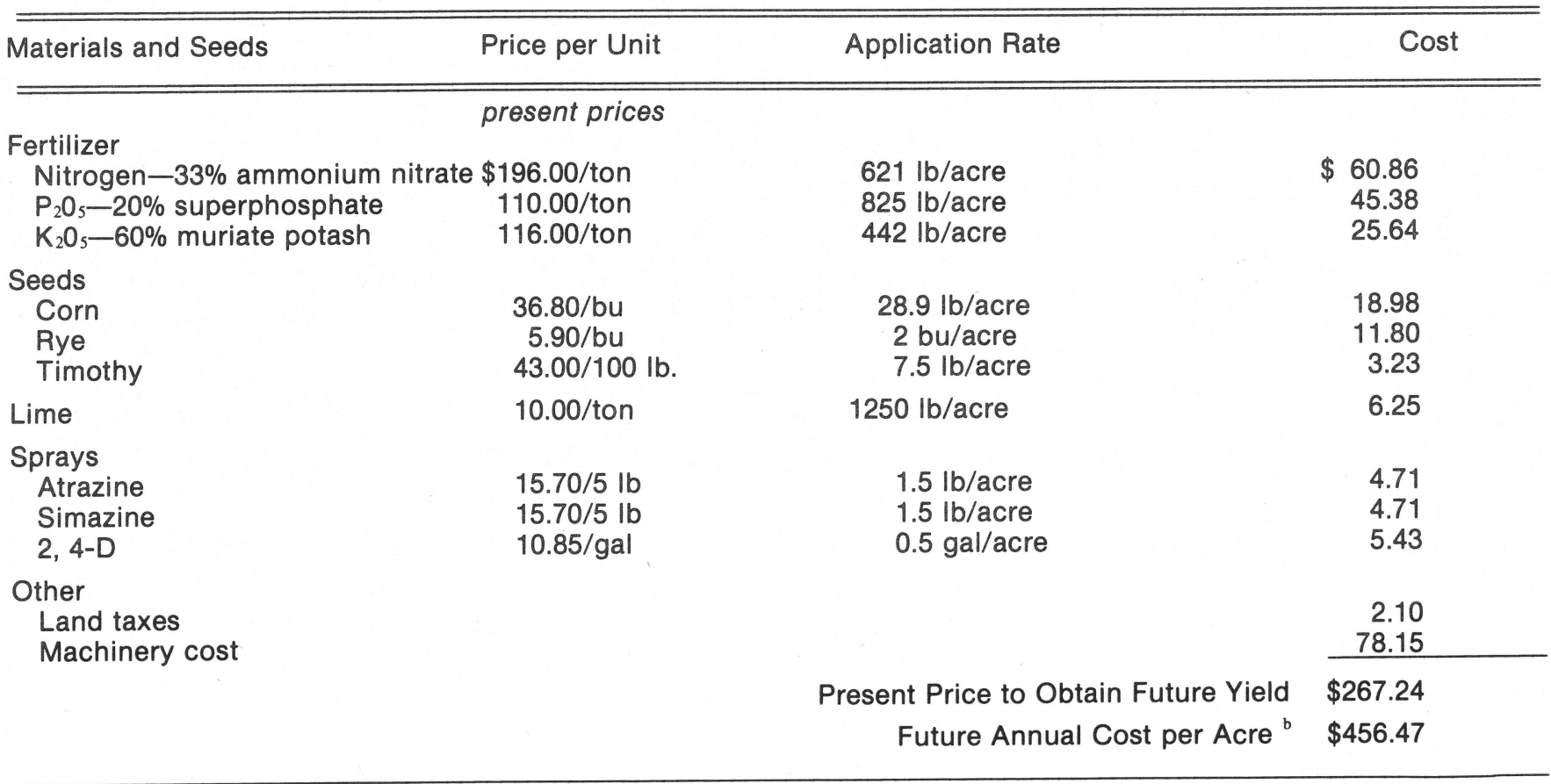




\section{Appendix Table 4.}

Present and Future Crop Yields of Corn, Rye, and Hay on Class II Land ${ }^{\mathrm{a}}$ With Adjustments for Harvesting and Feeding Losses

\begin{tabular}{|c|c|c|c|c|c|c|c|c|}
\hline \multirow[b]{2}{*}{ Yield } & \multicolumn{2}{|c|}{ Corn Silage } & \multicolumn{2}{|c|}{ Rye Silage } & \multicolumn{2}{|c|}{ Alfalfa Hay } & \multicolumn{2}{|c|}{ Clover Hay } \\
\hline & Present & Future & Present & Future & Present & Future & Present & Future \\
\hline Tons before loss & 20.00 & 30.00 & 2.98 & 4.49 & 3.50 & 5.50 & 3.15 & 5.15 \\
\hline $\begin{array}{l}\text { T.D.N. loss-percent of } \\
\text { standing yield }\end{array}$ & 8.10 & 8.10 & 23.60 & 23.60 & 30.80 & 30.80 & 30.80 & 30.80 \\
\hline $\begin{array}{l}\text { T.D.N. after loss- } \\
\text { percent of standing yield }\end{array}$ & 91.90 & 91.90 & 76.40 & 76.40 & 69.20 & 69.20 & 69.20 & 69.20 \\
\hline $\begin{array}{l}\text { Pounds of crop-after loss } \\
\text { Percent T.D.N. }\end{array}$ & $\begin{array}{r}36,760.00 \\
23.0\end{array}$ & $\begin{array}{r}55,140.00 \\
23.00\end{array}$ & $\begin{array}{r}4,560.00 \\
14.00\end{array}$ & $\begin{array}{r}6,860.00 \\
14.00\end{array}$ & $\begin{array}{r}4,844.00 \\
52.00\end{array}$ & $\begin{array}{r}7,612.00 \\
52.00\end{array}$ & $\begin{array}{r}4,359.60 \\
52.00\end{array}$ & $\begin{array}{r}7,127.60 \\
52.00\end{array}$ \\
\hline Pounds T.D.N.-after loss & $8,455.00$ & $12,682.20$ & 637.50 & 960.50 & $2,518.90$ & $3,960.00$ & $2,267.00$ & $3,706.35$ \\
\hline Percent crude protein ${ }^{c}$ & 2.67 & 2.67 & 2.21 & 2.21 & 10.40 & 10.40 & 9.70 & 9.70 \\
\hline $\begin{array}{l}\text { Pounds crude protein- } \\
\text { after loss }\end{array}$ & 981.50 & $1,472.24$ & 101.00 & 151.61 & 503.80 & 791.65 & 422.90 & 691.38 \\
\hline Tons crop-after loss & 18.38 & 27.57 & 2.28 & 3.43 & 2.42 & 3.81 & 2.18 & 3.56 \\
\hline
\end{tabular}

${ }^{a}$ Estimates of yields on land Classes I \& III: Corn Silage-Class I, 5 percent greater than Class II, Class III, 8 percent less than Class II; Rye SilageClass I, 4 percent greater than Class II, Class III, 9 percent less than Class II; Alfalfa-Grass Hay-Classes I \& II equal, Class III, 0.2 tons less; clover-grass hay-Classes I \& II equal, Class III, 0.22 tons less.
bAgricultural Planning Data for the Northeastern United States, Pennsylvania State University Experiment Station, A.E. \& R.S. 51 (University Park: The Pennsylvania State University, July, 1965), Tble 29, pp. 45-46.

${ }^{\mathrm{c}}$ From Appendix Table 14. 


\section{Appendix Table 5.}

Alfalfa, Timothy, Orchardgrass Hay-Estimated Per Acre Costs, Including Establishment, ${ }^{\text {a }}$ Using a Round Bale Feeding System-Present Costs for Present Yields ${ }^{b}$

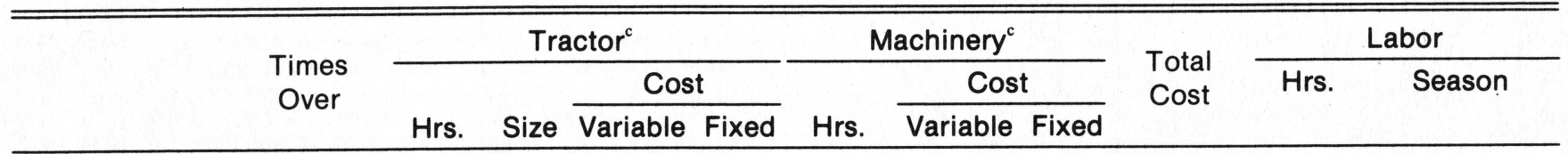

\section{Operation}

Spread fertilizer $\quad 1$

\begin{tabular}{|c|c|c|c|c|c|c|c|c|c|c|c|}
\hline & & & & & & Custom & & & & & \\
\hline Disc & 1 & 0.23 & $50 \mathrm{hp}$ & $\$ 0.28$ & $\$ 0.51$ & 0.23 & 0.39 & $\$ 1.29$ & 2.47 & 0.24 & Spring \\
\hline Sow & 1 & 0.30 & 50 hp & 0.36 & 0.66 & 0.30 & 0.32 & 1.20 & $2.59^{e}$ & 0.40 & Spring \\
\hline Spray-herbicide & 1 & 0.10 & $35 \mathrm{hp}$ & 0.09 & 0.16 & 0.10 & 0.03 & 0.21 & 0.49 & 0.20 & Spring \\
\hline Spray-insecticide & 2 & 0.20 & $35 \mathrm{hp}$ & 0.17 & 0.32 & 0.20 & 0.05 & 0.41 & 0.95 & 0.40 & $1 / 2 \mathrm{sp}, 1 / 2 \mathrm{sm}$ \\
\hline Mow & 3 & 1.05 & 50 hp & 1.26 & 2.31 & 1.50 & 1.10 & 9.71 & 14.38 & 1.35 & $1 / 3 \mathrm{sp}, 2 / 3 \mathrm{sm}$ \\
\hline Rake & 5 & 1.75 & $35 \mathrm{hp}$ & 1.49 & 2.80 & 1.75 & 0.53 & 2.98 & 7.80 & 1.90 & $1 / 3 \mathrm{sp}, 2 / 3 \mathrm{sm}$ \\
\hline Bale & 3 & 1.00 & $50 \mathrm{hp}$ & 1.20 & 2.20 & 1.00 & 1.00 & 18.52 & 22.92 & 1.50 & $1 / 3 \mathrm{sp}, 2 / 3 \mathrm{sm}$ \\
\hline Move bales & 3 & 1.00 & 50 hp & 1.20 & 2.20 & 1.00 & 0.15 & 1.28 & 4.83 & 1.50 & $1 / 3 \mathrm{sp}, 2 / 3 \mathrm{sm}$ \\
\hline & & & & & & & & $\$ 58.43$ & $\$ 7.49$ & & \\
\hline
\end{tabular}

adjustments to prorate establishment costs are shown in Appendix Table 9.

'Yields by land class and adjustments in yields to account for harvesting and feeding losses are given in Appendix Table 4.

'Tractor and machinery hours, sizes, and costs were taken from:

costs and Returns Guide for Crops in Virginia, Extension Division
Publication 607 (Blacksburg: Virginia Polytechnic Institute and State University, revised June, 1974), p. 22 and Table A, pp. 69-71.

${ }^{d}$ No allowance was made for cost differences between land classes.

Includes $\$ 0.05$ for truck cost. 
Appendix Table 5 Continued

\begin{tabular}{|c|c|c|c|}
\hline Materials and Seeds ${ }^{f}$ & Price per Unit ${ }^{\mathrm{g}}$ & Application Rate & Cost \\
\hline $\begin{array}{l}\text { Fertilizer: }^{\mathrm{h}} \\
\mathrm{P}_{2} \mathrm{O}_{5}-20 \% \text { superphosphate } \\
\mathrm{K}_{2} \mathrm{O}-60 \% \text { muriate potash }\end{array}$ & $\begin{array}{r}\$ 110.00 / \text { ton } \\
116.00 / \text { ton }\end{array}$ & $\begin{array}{l}500 \mathrm{lb} / \text { acre } \\
333.33 \mathrm{lb} / \text { acre }\end{array}$ & $\begin{array}{r}\$ 27.50 \\
19.53\end{array}$ \\
\hline Lime (custom applied) & $10.00 /$ ton & $1000 \mathrm{lb} / \mathrm{acre}(2 \mathrm{~T} / \mathrm{acre}$ each & 5.00 \\
\hline $\begin{array}{l}\text { Seeds: alfalfa } \\
\text { Sprays: herbicide: } 2,4-D B \\
\text { insecticides: } \\
\text { Guthion } \\
\text { Malathion }\end{array}$ & $\begin{array}{l}132.00 / 100 \mathrm{lb} . \\
18.23 / \mathrm{gal} \\
62.00 / 5 \mathrm{gal} \\
5.36 / 4 \mathrm{lb} .\end{array}$ & $\begin{array}{l}.38 \mathrm{gal} / \text { acre } \\
1.25 \mathrm{lb} / \text { acre }\end{array}$ & $\begin{array}{r}19.80 \\
6.84\end{array}$ \\
\hline Twine & $\begin{array}{l}12.00 / \mathrm{bale} \\
10,000 \mathrm{ft} / \mathrm{bale}\end{array}$ & $1200 \mathrm{ft} /$ acre & 1.44 \\
\hline \multicolumn{3}{|l|}{ Land taxes ${ }^{\mathrm{i}}$} & 2.10 \\
\hline & \multicolumn{2}{|c|}{ Total per acre cost, including establishment } & $\$ 146.83^{j}$ \\
\hline \multicolumn{3}{|c|}{ PER ACRE COST, ESTABLISHMENT COST PRORATED 5 YEARS } & $\$ 121.08^{\mathrm{a}}$ \\
\hline
\end{tabular}$$
\mathrm{f}
$$

f_. "A Plan for Integrating the Operations of West Virginia's Institutional Farms," College of Agriculture and Forestry (Morgantown West Virginia University, October, 1975).

${ }^{\mathrm{B} P}$ Prices obtained from:

Fertilizer-USDA, Agricultural Prices, Statistical Reporting Service, Crop Reporting Board Pr 1 (10-75) (Washington, D.C.: U.S. Government Printing Office, October, 1975), pp. 23-25.

Alfalfa Seed-Agricultural Prices, op. cit., September, 1975, p. 22.

Lime-Agricultural Stabilization and Conservation Service, Elkins, W. Va., February, 1976 (telephone)
Sprays-Southern States Cooperative, Morgantown, W. Va., February, 1976 (telephone). Twine-Southern States Cooperative, op. cit.

h "Fertilizer Recommendations for Topdressing Legume-Tall Grass Hay or Pasture (over $30 \%$ Legume)," West Virginia University Soil Testing Laboratory Sheet ML (Morgantown: West Virginia University, May, 1973).

West Virginia State Tax Department, Taxes Levied on Classified Assessed Valuations, Richard L. Dailey, LGR12:54 (Charleston: 1975 tax year).

${ }^{j}$ Cost does not include a charge for labor or land other than land taxes. 


\section{Appendix Table 6}

Alfalfa, Timothy, Orchardgrass Hay-Estimated Per Acre Costs, Including Establishment, Using a Round Bale Feeding System-Future Cost For Future Yields $^{\mathrm{a}}$

\begin{tabular}{|c|c|c|c|}
\hline Materials and Seeds & Price per Unit & Application Rate & Cost \\
\hline \multicolumn{4}{|c|}{ present prices } \\
\hline \multicolumn{4}{|l|}{ Fertilizer } \\
\hline $\begin{array}{l}\mathrm{P}_{2} 0^{5}-20 \% \text { superphosphate } \\
\mathrm{K}_{2} \mathrm{O}-60 \% \text { muriate potash }\end{array}$ & $\begin{array}{l}\$ 110.00 / \text { ton } \\
116.00 / \text { ton }\end{array}$ & $\begin{array}{l}600 \mathrm{lb} / \text { acre } \\
600 \mathrm{lb} / \text { acre }\end{array}$ & $\begin{array}{r}\$ 33.00 \\
34.80\end{array}$ \\
\hline Seed; alfalfa & 132.00/100 lb. & $15 \mathrm{lb} / \mathrm{acre}$ & 19.80 \\
\hline Lime & 10.00/ton & $1000 \mathrm{lb} / \mathrm{acre}$ & 5.00 \\
\hline \multicolumn{4}{|l|}{ Sprays } \\
\hline Herbicide-2,4-DB & $2.28 / p t$ & $3 \mathrm{pt} / \mathrm{acre}$ & 6.84 \\
\hline Insecticide: Guthion & $12.40 / \mathrm{gal}$ & $0.38 \mathrm{gal} / \mathrm{acre}$ & 4.71 \\
\hline Malathion & $1.34 / \mathrm{lb}$ & $1.25 \mathrm{lb} / \mathrm{acre}$ & 1.68 \\
\hline Twine & $\begin{array}{l}12.00 / \mathrm{bale} \\
10,000 \mathrm{ft} / \mathrm{bale}\end{array}$ & $1467 \mathrm{ft} /$ acre & 1.76 \\
\hline \multicolumn{4}{|l|}{ Other } \\
\hline Land taxes & & & 2.10 \\
\hline Machinery cost & & & 58.43 \\
\hline \multicolumn{3}{|c|}{ PRESENT COST TO OBTAIN FUTURE YIELD } & $\$ 168.12$ \\
\hline \multicolumn{3}{|c|}{ FUTURE COST PER ACRE } & $\$ 287.17$ \\
\hline \multicolumn{3}{|c|}{ FUTURE COST WITH PRORATED ESTABLISHED COSTS } & $\$ 243.18$ \\
\hline
\end{tabular}

anformation from Appendix Table 4 with adjustments made in amounts of fertilizer required to obtain future yields as estimated by Charles Sperow. WVU Extension agronomy specialist.
${ }^{b}$ Future cost was determined by inflating present cost by 70.81 percent. The inflation rate was determined by a linear regression analysis of price indexes for the years 1960-1975 and projecting to 1985. Cost does not include a labor charge or land cost other than land taxes. 


\section{Appendix Table 7.}

Clover, Timothy, Orchardgrass Hay-Estimated Per Acre Costs, Including Establishment, ${ }^{\mathrm{a}}$ Using a Round Bale Feeding System-Present Costs for Present Yields $^{\mathrm{b}}$

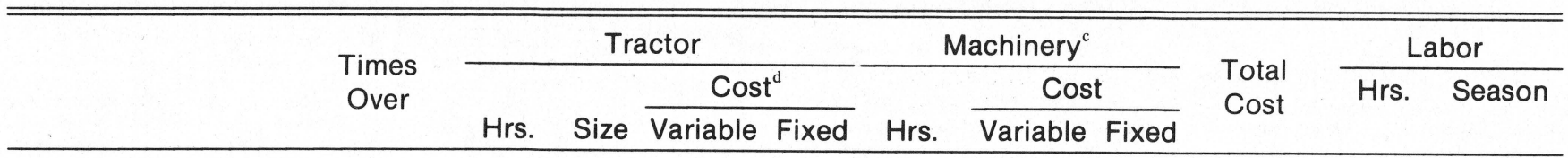

\section{Operation}

Spread fertilizer

\section{Disc}

Sow

Mow

Rake

¿ Bale

Move bales

\begin{tabular}{|c|c|c|c|}
\hline & & & \\
\hline 1 & 0.23 & $50 \mathrm{hp}$ & $\$ 0.28$ \\
\hline & 0.30 & $50 \mathrm{hp}$ & 0.36 \\
\hline & 0.70 & 50 hp & 0.84 \\
\hline & 1.05 & $35 \mathrm{hp}$ & 0.89 \\
\hline & 0.80 & $50 \mathrm{hp}$ & 0.96 \\
\hline & 0.80 & $50 \mathrm{hp}$ & 0.96 \\
\hline
\end{tabular}

\section{Custom}

$\$ 0.51 \quad 0.23$

$0.66 \quad 0.30$

$\begin{array}{ll}1.54 & 0.70\end{array}$

$\begin{array}{ll}1.68 & 1.05\end{array}$

$\begin{array}{ll}1.76 & 0.80\end{array}$

$\begin{array}{ll}1.76 & 0.80\end{array}$

$\begin{array}{rr}\$ 0.39 & 1.29 \\ 0.32 & 1.20 \\ 0.74 & 6.48 \\ 0.32 & 1.79 \\ 0.80 & 14.80 \\ 0.12 & 1.02\end{array}$

$\$ 2.00$

2.47

$2.59^{\mathrm{c}}$

9.60

4.68

18.32

0.12

1.02

\begin{tabular}{rrr}
18.32 & 1.30 & Spring \\
3.86 & 1.30 & Spring \\
\hline$\$ 43.52$ & 5.64
\end{tabular}

${ }^{2}$ Adjustments to prorate establishment costs are shown in Appendix Table 9.

${ }^{b}$ Yields by land class and adjustments in yields to account for harvesting and feeding losses are given in Appendix Table 4.

'Tractor and machinery hours, sizes, and costs were taken from Cost and Returns Guide for Crops in Virginia, Extension Division Publication 607
(Blacksburg: Virginia Polytechnic Institute and State University, revised June, 1974), p. 28 and Table A, pp. 69-71.

${ }^{\mathrm{d}}$ No allowance was made for cost differences between land classes.

eIncludes $\$ 0.05$ for truck cost.

(continued) 


\section{Appendix Table 7 Continued}

\begin{tabular}{|c|c|c|c|}
\hline Materials and Seeds ${ }^{\mathrm{f}}$ & Price per Unit ${ }^{\mathrm{g}}$ & Application Rate & Cost \\
\hline $\begin{array}{l}\text { Fertilizer: }^{\text {h }} \text { nitrogen }-33 \% \\
\text { Ammonia nitrate } \\
\mathrm{P}_{2} \mathrm{O}_{5}-20 \% \text { superphosphate } \\
\mathrm{K}_{2} \mathrm{O}-60 \% \text { muriate potash }\end{array}$ & $\begin{array}{l}\$ 196.00 / \text { ton } \\
110.00 / \text { ton } \\
116.00 / \text { ton }\end{array}$ & $\begin{array}{l}152 \mathrm{lb} / \text { acre } \\
375 \mathrm{lb} / \text { acre } \\
292 \mathrm{lb} / \text { acre }\end{array}$ & $\begin{array}{r}14.90 \\
20.63 \\
16.94\end{array}$ \\
\hline Lime (custom applied) & 10.00/ton & $\begin{array}{l}650 \mathrm{lb} / \mathrm{acre}(2 \mathrm{~T} / \mathrm{acre} \text { each } \\
6 \mathrm{yrs} .)\end{array}$ & 3.25 \\
\hline Seeds: clover & $100.00 / 100 / \mathrm{lb}$ & $5 \mathrm{lb} / \mathrm{acre}$ & 5.00 \\
\hline Twine & $\begin{array}{l}12.00 / \mathrm{bale} \\
10,000 \mathrm{lb} / \mathrm{bale}\end{array}$ & $900 \mathrm{ft} /$ acre & 1.08 \\
\hline \multicolumn{3}{|l|}{ Land taxes ${ }^{i}$} & 2.10 \\
\hline \multicolumn{3}{|c|}{ TOTAL PER ACRE COST, INCLUDING ESTABLISHMENT } & $\$ 107.42^{\mathrm{j}}$ \\
\hline \multicolumn{3}{|c|}{ PER ACRE COST, ESTABLISHMENT COST PRORATED 5 YEARS } & $\$ 99.37^{\mathrm{a}}$ \\
\hline
\end{tabular}

f"A Plan for Integrating the Operations of West Virginia's Institutional Farms," College of Agriculture and Forestry (Morgantown: West Virginia University, October, 1975).

${ }^{8}$ Prices obtained from:

Fertilizer-USDA, Agricultural Prices, Statistical Reporting Service, Crop Reporting Board $\operatorname{Pr} 1$ (10-75) Washington, D.C.: U.S. Government Printing Office, October, 1975), pp. 23-25.

Clover Seed-Agricultural Prices, op. cit., September, 1975, p. 22.

Lime-Agricultural Stabilization and Conservation Service, Elkins, W. Va., February, 1976 (telephone).
Twine-Southern States Cooperative, Morgantown, W. Va., February, 1976 (telephone).

hu'Fertilizer Recommendations for Topdressing Clover-Tall Grass Hay or Pasture (over 30\% Legume)," West Virginia University Soil Testing Laboratory Sheet ML (Morgantown: West Virginia University, October, 1976).

West Virginia State Tax Department. Taxes Levied on Classified Assessed Valuations, Richard L. Dailey, LGR 12:54 (Charleston: 1975 tax year).

${ }^{j}$ Cost does not include a charge for labor or land other than land taxes. 


\section{Appendix Table 8}

Clover, Timothy, Orchardgrass, Hay-Estimated Per Acre Costs, Including

Establishment, Using a Round Bale Feeding System-Future Cost for Future Yields $^{\mathrm{a}}$

\begin{tabular}{|c|c|c|c|}
\hline Materials and Seeds & Price per Unit & Application Rate & Cost \\
\hline & present prices & & \\
\hline $\begin{array}{l}\text { Fertilizer } \\
\text { Nitrogen-33\% ammonia nitrate } \\
\mathrm{P}_{2} \mathrm{O}_{5}-20 \% \text { superphosphate } \\
\mathrm{K}_{2} \mathrm{O}-60 \% \text { muriate potash }\end{array}$ & $\begin{array}{l}\$ 196.00 / \text { ton } \\
110.00 / \text { ton } \\
116.00 / \text { ton }\end{array}$ & $\begin{array}{l}152 \mathrm{lb} / \text { acre } \\
475 \mathrm{lb} / \text { acre } \\
525 \mathrm{lb} / \text { acre }\end{array}$ & $\begin{array}{r}\$ 14.90 \\
26.13 \\
30.45\end{array}$ \\
\hline Seed red clover & $100.00 / 100 \mathrm{lb}$ & $5 \mathrm{lb} / a c r e$ & 5.00 \\
\hline Lime & $10.00 /$ ton & $650 \mathrm{lb} / \mathrm{acre}$ & 3.25 \\
\hline Twine & $\begin{array}{l}12.00 / \mathrm{bale} \\
10,000 \mathrm{ft} / \mathrm{bale}\end{array}$ & $1373 \mathrm{ft} /$ acre & 1.65 \\
\hline \multirow[t]{4}{*}{$\begin{array}{l}\text { Other } \\
\text { Land taxes } \\
\text { Machinery cost }\end{array}$} & & & $\begin{array}{r}2.10 \\
43.52 \\
\end{array}$ \\
\hline & & Present Cost to Obtain Future Yield & $\$ 127.00$ \\
\hline & & Future Cost per Acre ${ }^{\mathrm{b}}$ & $\$ 216.93$ \\
\hline & & st with Prorated Establishment Costs & $\$ 203.18$ \\
\hline
\end{tabular}

anformation from Appendix Table 4 with adjustments made in amounts of fertilizer required to obtain future yields as estimated by Charles Sperow,

WVU Extension agronomy specialist.

${ }^{b}$ Future cost was determined by inflating present cost by 70.81 percent. The inflation rate was determined by a linear regression analysis of price indexes for the years 1960-1975 and projecting to 1985. Cost does not include a labor or land charge other than land taxes. 
Appendix Table 9.

Present and Future Hay Production Costs and Labor Requirements with Establishment Costs Included in Year One and with Establishment Costs Prorated Over a Five-Year Period

\begin{tabular}{|c|c|c|c|c|c|c|c|c|}
\hline & \multicolumn{4}{|c|}{ Alfalfa } & \multicolumn{4}{|c|}{ Clover } \\
\hline & Present & Future & Hours & $\begin{array}{l}\text { Labor } \\
\text { Season }\end{array}$ & Present & Future & Hours & $\begin{array}{l}\text { Labor } \\
\text { Season }\end{array}$ \\
\hline & \multicolumn{4}{|c|}{ Present prices } & \multicolumn{4}{|c|}{ Present prices } \\
\hline $\begin{array}{l}\text { Disc } \\
\text { Sow } \\
\text { Spray herbicide } \\
\text { Seed } \\
\text { Herbicide }\end{array}$ & $\begin{array}{r}2.47 \\
2.59 \\
0.49 \\
19.80 \\
6.84 \\
\end{array}$ & $\begin{array}{r}2.47 \\
2.59 \\
0.49 \\
19.80 \\
6.84 \\
\end{array}$ & $\begin{array}{c}0.24 \\
0.40 \\
0.20 \\
- \\
-\end{array}$ & $\begin{array}{l}\text { Spring } \\
\text { Spring } \\
\text { Spring } \\
- \\
-\end{array}$ & $\begin{array}{c}2.47 \\
2.59 \\
- \\
5.00 \\
-\end{array}$ & $\begin{array}{l}\$ 2.47 \\
2.59 \\
- \\
5.00 \\
-\end{array}$ & $\begin{array}{c}0.24 \\
0.40 \\
- \\
- \\
-\end{array}$ & $\begin{array}{c}\text { Spring } \\
\text { Spring } \\
- \\
- \\
-\end{array}$ \\
\hline $\begin{array}{l}\text { Establishment cost } \\
\text { Establishment cost }\end{array}$ & $\$ 32.19$ & $\$ 32.19$ & - & - & $\$ 10.06$ & $\$ 10.06$ & & \\
\hline 5 years & $\$ 6.44$ & $\$ 6.44$ & - & - & $\$ 2.01$ & $\$ 2.01$ & - & - \\
\hline $\begin{array}{l}\text { Total cost including } \\
\text { establishment }^{\mathrm{a}}\end{array}$ & $\$ 148.83$ & $\$ 168.12$ & - & - & $\$ 107.42$ & $\$ 127.00$ & - & - \\
\hline Establishment cost & -32.19 & -32.19 & - & - & -10.06 & -10.06 & - & - \\
\hline Cost, less establishment & $\$ 114.64$ & $\$ 135.93$ & - & - & $\$ 97.36$ & $\$ 116.94$ & - & - \\
\hline Prorated establishment cost & +6.44 & +6.44 & - & - & +2.01 & +2.01 & - & - \\
\hline $\begin{array}{l}\text { Per acre cost, } \\
\text { Establishment prorated }\end{array}$ & $\$ 121.08$ & $\$ 142.37$ & - & - & $\$ 99.37$ & $\$ 118.95$ & - & - \\
\hline
\end{tabular}




\section{Appendix Table 9 Continued}

\begin{tabular}{|c|c|c|c|c|c|c|c|c|}
\hline & \multicolumn{4}{|c|}{ Alfalfa } & \multicolumn{4}{|c|}{ Clover } \\
\hline & Present & Future & Hours & $\begin{array}{l}\text { Labor } \\
\text { Season }\end{array}$ & Present & Future & Hours & $\begin{array}{l}\text { Labor } \\
\text { Season }\end{array}$ \\
\hline & \multicolumn{4}{|c|}{ Present prices } & \multicolumn{4}{|c|}{ Present prices } \\
\hline $\begin{array}{l}\text { Inflated } 70.81 \% \text { to } \\
\text { future cost }\end{array}$ & - & $\$ 243.18$ & - & - & - & $\$ 203.18$ & - & - \\
\hline Establishment labor & - & - & 0.84 & - & - & - & 0.64 & - \\
\hline $\begin{array}{l}\text { Prorated establishment } \\
\text { labor }\end{array}$ & - & - & 0.17 & - & - & - & 0.13 & - \\
\hline $\begin{array}{l}\text { Total spring labor } \\
\text { establishment labor } \\
\text { prorated }\end{array}$ & - & - & 2.45 & - & - & - & 2.63 & - \\
\hline $\begin{array}{l}\text { Total annual labor } \\
\text { Establishment labor } \\
\text { prorated }\end{array}$ & - & - & 6.81 & - & - & - & 5.13 & - \\
\hline $\begin{array}{l}\text { Total spring labor } \\
\text { establishment in year } 1^{a}\end{array}$ & - & - & 3.13 & - & - & - & 3.14 & - \\
\hline $\begin{array}{l}\text { Total annual labor } \\
\text { establishment in year } 1^{\mathrm{a}}\end{array}$ & - & - & 7.49 & - & - & - & 7.49 & - \\
\hline
\end{tabular}

${ }^{a}$ Taken from the Crop Budgets, Appendix Tables 2 through 8. 


\section{Appendix Table 10.}

Improved Permanent Pasture-Estimated Per Acre Costs-Present Costs for Present Yields ${ }^{a}$

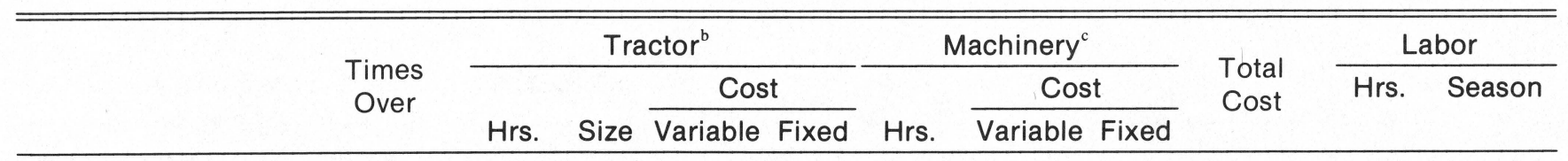

Operation

Spread

fertilizer

Clip

1

Custom

$\$ 2.00$

రి

$\begin{array}{lllllllll}0.25 & 35 \mathrm{hp} & \$ 0.21 & \$ 0.40 & 0.25 & \$ 0.06 & \$ 0.81 & \frac{1.48}{0.30} & \text { Summer } \\ \text { Operations Total } & & & & & \$ 3.48 & 0.30 & \end{array}$

\begin{tabular}{lllr} 
Materials $^{\mathrm{d}}$ & Price per Unit & Application Rate & Cost \\
\hline Fertilizer $^{\mathrm{f}}$ & & & \\
$\mathrm{P}_{2} \mathrm{O}_{5}-20 \%$ superphosphate & $5.5 \$ / \mathrm{lb}$ & $270 \mathrm{lb} /$ acre & $\$ 14.85$ \\
$\mathrm{~K}_{2} \mathrm{O}-60 \%$ muriate potash & $5.84 / \mathrm{lb}$ & $100 \mathrm{lb} /$ acre & 5.80 \\
Lime (custom applied) & $\$ 10.00 /$ ton & $2 \mathrm{~T} /$ acre each 6 years) & 3.25 \\
Land taxes & $650 \mathrm{lb} /$ acre & & 2.10 \\
& & Total per acre cost $\$ 26.00^{\mathrm{h}}$
\end{tabular}


'Yields by type of pasture and by land class are given in Appendix Table 13. Yields are given at a 75 percent recovery rate.

'Tractor and machinery hours, sizes, and costs were taken from machinery hours, sizes, and costs were taken from Division Publication 607 (Blacksburg: Virginia Polytechnic Institute and State University, revised June, 1974), Table C, p. 56 and Table A, pp. 69-71.

'No allowance was made for cost differences between land classes.

d

"A Plan for Integrating the Operations of West Virginia's Institutional Farms," College of Agriculture and Forestry (Morgantown: West Virginia University, October, 1975).

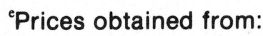

Fertilizer-USDA, Agricultural Prices, Statistical Reporting Service, Crop Reporting Board Prl (10-75) (Washington, D.C.: U.S. Government Printing Office, October, 1975), p. 22.

Lime-Agricultural Stabilization and Conservation Service, Elkins,
BLUEGRASS- "Fertilizer Recommendations for Alternate Year Topdressing Testing (Morgantown: West Virginia University me moderate level but was considered sufficient to raise production to a good level within a few years and then rates may be decreased some to maintain the good level of production, thereby decreasing annual maintenance costs.

'West Virginia State Tax Department, Taxes Levied on Classified Assessed Valuations, Richard L. Dailey, LGR 12:54 (Charleston: 1975 tax year).

${ }^{\mathrm{h}}$ Cost does include a charge for labor or land other than land taxes. 


\section{Appendix Table 11.}

Improved Permanent Pasture-Estimated Per Acre Costs-Future Cost for Future Yields

\begin{tabular}{|c|c|c|c|}
\hline Materials and Seeds & Price per Unit & Application Rate & Cost \\
\hline & (Present prices) & & \\
\hline \multicolumn{4}{|l|}{ Fertilizer } \\
\hline $\begin{array}{l}\mathrm{P}_{2} \mathrm{O}_{5}-20 \% \text { superphosphate } \\
\mathrm{K}_{2} \mathrm{O}-60 \% \text { muriate potash }\end{array}$ & $\begin{array}{l}5.5 \$ / \mathrm{lb} \\
5.8 థ / \mathrm{lb}\end{array}$ & $\begin{array}{l}325 \mathrm{lb} / \text { acre } \\
160 \mathrm{lb} / \text { acre }\end{array}$ & $\begin{array}{r}\$ 17.88 \\
9.28\end{array}$ \\
\hline Lime & $\$ 10.00 /$ ton & $1275 \mathrm{lb} / \mathrm{acre}$ & 6.38 \\
\hline \multirow[t]{3}{*}{ Machinèry Cost } & & & 3.48 \\
\hline & & Present cost to obtain future yield & 39.12 \\
\hline & & Future cost per acre & $\$ 66.82$ \\
\hline $\begin{array}{l}\text { anformation from Appendix Table } 10 \mathrm{~V} \\
\text { fertilizer required to obtain future yiel } \\
\text { WVU Extension agronomy specialist. } \\
\text { to be } 50 \text { percent higher than present }\end{array}$ & $\begin{array}{l}\text { tments made in amounts of } \\
\text { mated by Charles Sperow, } \\
\text { sture yields were estimated }\end{array}$ & $\begin{array}{l}{ }^{b} \text { Future cost was determined by inflating present cc } \\
\text { inflation rate was determined by a linear regre } \\
\text { indexes for the years } 1960-1975 \text { and projecting } \\
\text { include a labor or land charge other than land ta }\end{array}$ & $\begin{array}{l}\text { st by } 70.18 \text { percent. The } \\
\text { ssion analysis of price } \\
\text { to } 1985 \text {. Cost does not } \\
\text { ees. }\end{array}$ \\
\hline
\end{tabular}


Appendix Table 12.

Unimproved Permanent Pasture-Estimated Per Acre Costs-Present and Future

Costs $^{\mathrm{a}}$

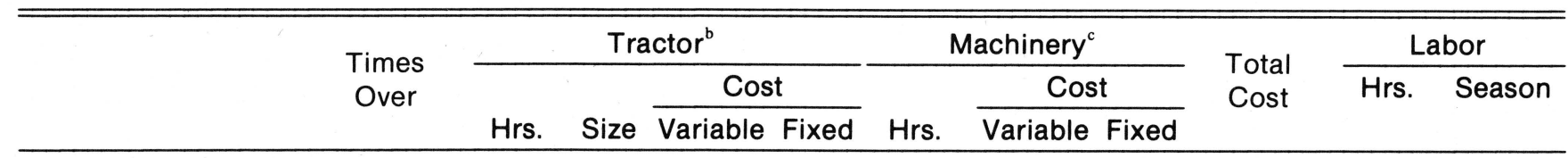

\section{Operation}

Clip

(once every two years)

0.5
$0.30 \quad 35 \mathrm{hp} \quad \$ 0.26$

Land taxes ${ }^{\mathrm{d}}$

\section{Laxes}

${ }^{\text {a} Y i e l d s ~ b y ~ t y p e ~ o f ~ p a s t u r e ~ a n d ~ b y ~ l a n d ~ c l a s s ~ a r e ~ g i v e n ~ i n ~ A p p e n d i x ~ T a b l e ~} 13$. Yields are given at a 75 percent recovery rate.

${ }^{b}$ Tractor and machinery hours, sizes, and costs were taken from Costs and Returns Guide for Crops in Virginia, Extension Division Publication 607 (Blacksburg: Virginia Polytechnic Institute and State University, revised June, 1974), p. 58, and Table A, pp. 69-71.

'No allowance was made for cost differences between land classes.

\section{$\begin{array}{lllllll}\$ 0.48 & 0.30 & \$ 0.08 & \$ 0.98 & \$ 1.80 & 0.35 & \text { Summer }\end{array}$}

Operations Total $\$ 1.80 \quad 0.35$

Total per Acre Present Cost $\$ 3.90$ Future per Acre Cost ${ }^{\mathrm{e}} \quad \$ 6.66$
'West Virginia State Tax Department, Taxes Levied on Classified Assessed Valuations, Richard L. Dailey, LGE 12:54 (Charleston: 1975 tax year).

${ }^{e}$ Future cost was determined by inflating present cost by 70.18 percent. The inflation rate was determined by a linear regression analysis of price indexes for the years 1960-1975 and projecting to 1985. Cost does not include a labor or land charge other than land taxes. 


\section{Appendix Table 13.}

Pasture Yields ${ }^{a}$ by Type of Pasture, Land Class, ${ }^{b}$ and Month in Pounds of Hay Equivalent, T.D.N. and Crude Protein ${ }^{\mathrm{c}}$

\begin{tabular}{|c|c|c|c|c|c|c|}
\hline \multicolumn{7}{|l|}{ Month } \\
\hline $\begin{array}{l}\text { Types of } \\
\text { Pasture }\end{array}$ & May & June & July & August & September & October \\
\hline $\begin{array}{l}\text { Aftermath } \\
\text { Alfalfa-Grass, Clas } \\
\text { Ib hay equiv. } \\
\text { Ib T.D.N. } \\
\text { Ib crude protein }\end{array}$ & & & & & & $\begin{array}{r}750.00 \\
390.00 \\
78.00\end{array}$ \\
\hline $\begin{array}{l}\text { Alfalfa-Grass, Clas } \\
\text { Ib hay equiv. } \\
\text { Ib T.D.N. } \\
\text { Ib crude protein }\end{array}$ & & & & & & $\begin{array}{r}712.50 \\
370.50 \\
74.10\end{array}$ \\
\hline $\begin{array}{l}\text { Clover-Grass, Class } \\
\text { Ib hay equiv. } \\
\text { Ib T.D.N. } \\
\text { Ib crude protein }\end{array}$ & & & & & $\begin{array}{r}375.00 \\
195.00 \\
36.38\end{array}$ & $\begin{array}{r}375.00 \\
195.00 \\
36.38\end{array}$ \\
\hline $\begin{array}{l}\text { Clover-Grass, Clas } \\
\text { Ib hay equiv. } \\
\text { Ib T.D.N. } \\
\text { Ib crude protein }\end{array}$ & & s & & & $\begin{array}{r}348.75 \\
181.35 \\
33.83\end{array}$ & $\begin{array}{r}348.75 \\
181.35 \\
33.83\end{array}$ \\
\hline $\begin{array}{l}\text { Permanent } \\
\text { Improved, Class I } \\
\text { Ib hay equiv. } \\
\text { Ib T.D.N. } \\
\text { Ib crude protein }\end{array}$ & $\begin{array}{r}1350.46 \\
703.86 \\
108.59\end{array}$ & $\begin{array}{r}599.48 \\
312.45 \\
48.20\end{array}$ & $\begin{array}{r}467.72 \\
243.78 \\
37.60\end{array}$ & $\begin{array}{r}395.25 \\
206.00 \\
31.78\end{array}$ & $\begin{array}{r}289.86 \\
151.08 \\
23.30\end{array}$ & $\begin{array}{r}171.28 \\
89.27 \\
13.77\end{array}$ \\
\hline $\begin{array}{l}\text { Improved, Class II } \\
\text { Ib hay equiv. } \\
\text { Ib T.D.N. }\end{array}$ & $\begin{array}{r}1337.09 \\
696.89\end{array}$ & $\begin{array}{l}593.54 \\
309.35\end{array}$ & $\begin{array}{l}463.09 \\
241.36\end{array}$ & $\begin{array}{l}391.34 \\
203.97\end{array}$ & $\begin{array}{l}286.99 \\
149.58\end{array}$ & $\begin{array}{r}169.58 \\
88.38\end{array}$ \\
\hline
\end{tabular}


Ib crude protein

Improved, Class III

Ib hay equiv.

Ib T.D.N.

Ib crude protein

Improved, Class IV

Ib hay equiv.

Ib T.D.N.

Ib crude protein

Improved, Class VI

Ib hay equiv.

Ib T.D.N.

lb crude protein

Unimproved, Classes

$\omega$

\section{VI \& VII}

Ib hay equiv.

Ib T.D.N.

Ib crude protein
1285.66

670.09

103.37

1158.25

624.53

93.12

1025.00

552.68

82.41

655.00

353.18

52.66
570.71

297.45

45.88

514.15

277.23

41.34

455.00

245.34

36.58

395.00

212.98

31.76
445.28

232.08

35.80

401.15

216.30

32.25

355.00

191.42

28.54

\subsection{0 \\ 150.98 \\ 22.51}

376.29

196.12

30.25

339.00

182.79

27.26

300.00

161.76

24.12

275.95

143.82

22.19

248.60

133.72

220.00

118.62

175.00

94.36

14.07
19.99

17.69

163.06

84.99

13.11

146.90

79.21

11.81

130.00

70.10

10.45

125.00

125.00

67.40

10.05
60.00

32.35

4.82

aYields were obtained from the farm plan of one of the five study farms as prepared by Professor George E. Toben for the Allegheny Highlands Project. Future yields were estimated to be 50 percent greater and were determined by calculating a weighted average for each month. For example, using Permanent Improved pasture on Class I land: May yielded $1,337.09 \mathrm{lb}$ hay eq., June-593.54 lb hay eq., Oct.-169.58 lb hay eq. May contributed 41 percent of the total yield, June contributed 18 percent of the total yield and Oct. contributed 5 percent. The yield for all six months was summed to give the total yield. This yield was then increased by 50 percent. Total yield for the example was $3,241.09 \mathrm{lbs}$ hay eq. Fifty percent of this value is $\$ 1,620.82$. Each month was then allotted a portion of the 50 percent increase according to the percent each month contributed to the total. May contributed 41 percent, therefore, May yield was increased by 41 percent of $\$ 1,620.82$ or $665.54 \mathrm{lb}$ hay eq. giving a total future yield in May of $\$ 1,337.09$

and $664.54=2,001.63 \mathrm{lb}$ hay equivalent. Each of the other months was treated the same way.

${ }^{\mathrm{b}}$ Adjustment in yields between land classes were made as follows: aftermath-Alfalfa, Class I \& II equal, Class III 5 percent less; clover, Class I \& II equal, Class III 7 percent less; permanent-Class VI \& VII equal and used as the base, Class IV 13 percent greater than VI \& VII, Class III 11 percent greater than IV, Class II 4 percent greater than III,Class I 1 percent greater than II. Adjustment percentages were calculated from information obtained from: "Estimated Average Acre Yield of Principal Crops," West Virginia Technical Guide LRA-126, Section II-D (Morgantown: Soil Conservation Service, February, 1970).

'T.D.N. and C.P. percentages used to convert Ibs. hayeq. and Ib T.D.N. and C.P. were taken from the average rows of Appendix Table 14 


\section{Appendix Table 14.}

Percentages of Total Digestible Nutrients and Crude Protein, on an As Fed Basis, Provided by Crops ${ }^{\mathrm{a}}$

\begin{tabular}{|c|c|c|c|c|c|}
\hline \multirow[b]{2}{*}{ Crop } & \multirow[b]{2}{*}{$\begin{array}{l}\text { Percent } \\
\text { Dry } \\
\text { Matter }\end{array}$} & \multicolumn{2}{|c|}{ Dry Matter Basis } & \multirow[b]{2}{*}{$\begin{array}{l}\text { Percent } \\
\text { TDN } \\
\text { as Fed }\end{array}$} & \multirow[b]{2}{*}{$\begin{array}{l}\text { Percent } \\
\text { Crude Protein } \\
\text { as Fed }\end{array}$} \\
\hline & & $\begin{array}{c}\text { Percent } \\
\text { TDN }\end{array}$ & $\begin{array}{l}\text { Percent } \\
\text { Crude } \\
\text { Protein }\end{array}$ & & \\
\hline $\begin{array}{l}\text { Silage } \\
\text { Corn } \\
\text { Rye }^{b}\end{array}$ & $\begin{array}{c}33.00 \\
-\end{array}$ & $\begin{array}{c}70.00 \\
-\end{array}$ & $\begin{array}{c}8.10 \\
-\end{array}$ & $\begin{array}{l}23.00 \\
14.00\end{array}$ & $\begin{array}{l}2.67 \\
2.21\end{array}$ \\
\hline $\begin{array}{l}\text { Hay, aftermath pasture } \\
\text { and permanent pasture } \\
\text { Alfalfa-Grass }\end{array}$ & & & & & \\
\hline $\begin{array}{l}\text { Alfalfa } \\
\text { Orchardgrass } \\
\text { Timothy } \\
\text { Average analysis }\end{array}$ & $\begin{array}{l}89.20 \\
88.30 \\
88.40 \\
88.63\end{array}$ & $\begin{array}{l}58.00 \\
57.00 \\
61.00 \\
58.67\end{array}$ & $\begin{array}{r}17.10 \\
9.70 \\
8.50 \\
11.77\end{array}$ & $\begin{array}{l}51.00 \\
50.30 \\
53.90 \\
52.00\end{array}$ & $\begin{array}{r}15.30 \\
8.60 \\
7.50 \\
10.40\end{array}$ \\
\hline $\begin{array}{l}\text { Clover-Grass } \\
\text { Clover } \\
\text { Orchardgrass } \\
\text { Timothy } \\
\text { Average analysis }\end{array}$ & $\begin{array}{l}87.70 \\
88.30 \\
88.40 \\
88.13\end{array}$ & $\begin{array}{l}59.00 \\
57.00 \\
61.00 \\
59.00\end{array}$ & $\begin{array}{r}14.90 \\
9.70 \\
8.50 \\
11.03\end{array}$ & $\begin{array}{l}51.70 \\
50.30 \\
53.90 \\
52.00\end{array}$ & $\begin{array}{r}13.10 \\
8.60 \\
7.50 \\
9.70\end{array}$ \\
\hline
\end{tabular}

ational Academy of Sciences, Nutrient Requirements of Beef Cattle, Subcommittee on Beef Cattle Nutrition, National Research Council, Fourth Revised Edition (Washington, D.C.: National Academy of Sciences, 
Appendix Table 15.

Machinery Complements ${ }^{\mathrm{a}}$ and Costs $^{\mathrm{b}}$ for the Three Alternative Feeding Systems Based on a 100-Cow Replacement Unit Herd

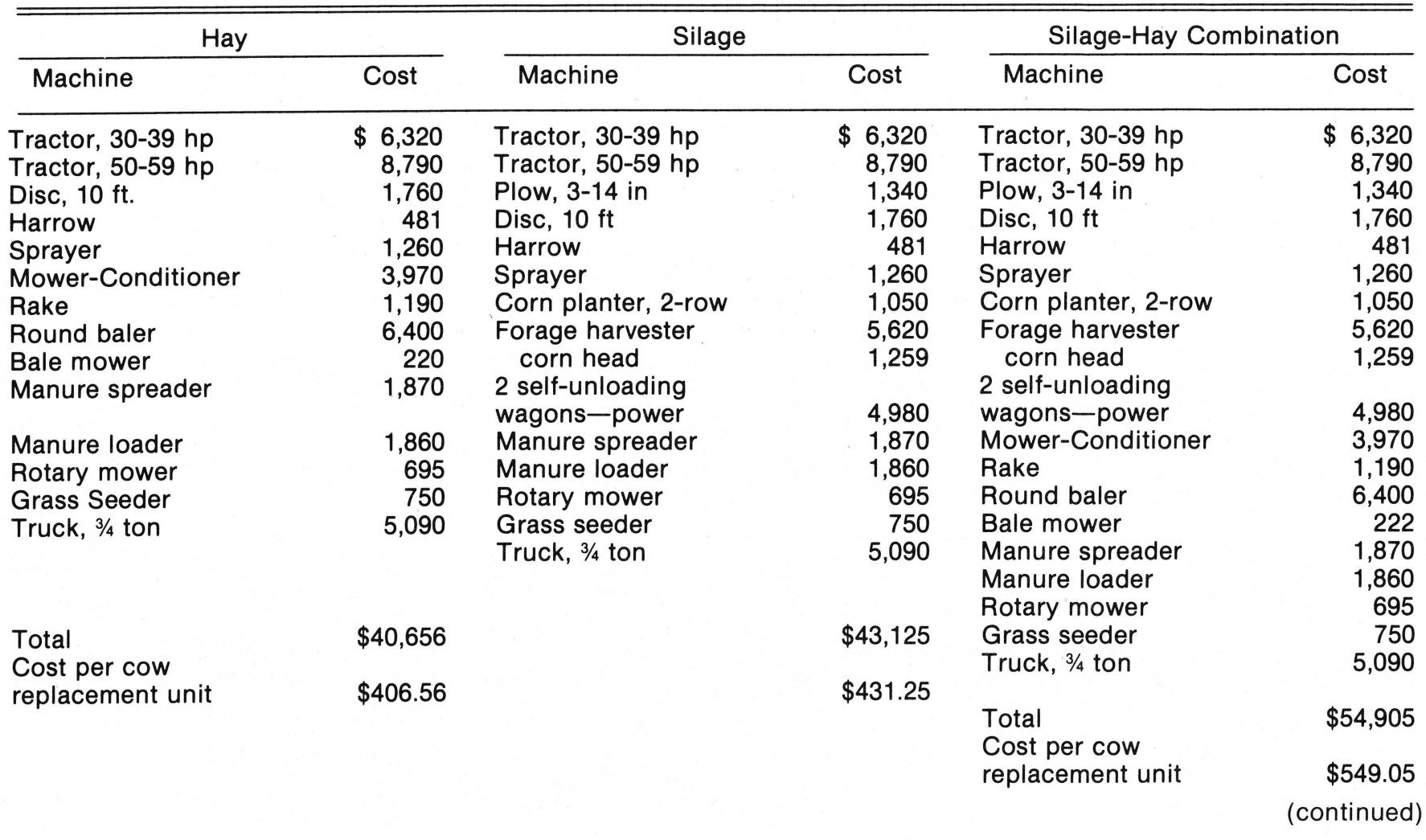




\section{Appendix Table 15 Continued}

aased on information obtained from Alfred L. Barr, George E. Toben, and Charles C. Wilson, Jr., Resources, Production, and Income on Eastern West Virginia Beef Cattle Farms, West Virginia University Agricultural Experiment Station Bulletin 546 (Morgantown: West Virginia University, 1967), Table 28, p. 37, and estimates given by WVU agricultural Extension specialists.

'Machinery costs from USDA, Agricultural Prices, Statistical Reporting Service, Crop Reporting Board, Prl (1-76) (Washington, D.C. U.S. Government Printing Office, January 30,1976$)$, pp. 49-50, and prices obtained from local machinery dealers in the Morgantown, W.Va. area. 


\section{Appendix Table 16.}

Estimated Annual Livestock Expenses and Labor Requirements Per Cow Replacement Unit (based on a 100-cow herd) for Three Alternative Feeding Systems

\begin{tabular}{|c|c|c|c|c|c|c|}
\hline \multirow[t]{2}{*}{ Item } & \multirow[t]{2}{*}{ Unit } & \multirow[t]{2}{*}{ Amount } & \multirow{2}{*}{$\begin{array}{c}\text { Price Per } \\
\text { Unit }\end{array}$} & \multicolumn{3}{|c|}{ Value $^{\mathrm{a}}$} \\
\hline & & & & Silage Only & Silage \& Hay & Hay Only \\
\hline $\begin{array}{l}\text { Expenses } \\
\text { Minerals \& salt }{ }^{\mathrm{b}} \\
\text { Veterinary and medicine }^{\mathrm{c}} \\
{\text { Hauling \& } \text { marketing }^{\mathrm{d}}}^{\text {Electricity }^{\mathrm{e}}} \\
\text { Livestock insurance }^{\mathrm{f}} \\
\text { Livestock taxes }^{\mathrm{g}} \\
\text { Feeding equipment }^{\mathrm{h}} \\
\text { Equipment repair }^{\mathrm{i}} \\
\text { Building insurance }^{\mathrm{j}} \\
\text { Building taxes }^{\mathrm{j}} \\
\text { Building depreciation }^{\mathrm{j}} \\
\text { Death loss }^{\mathrm{k}} \\
\text { Bull depreciation }^{1} \\
\text { Cow depreciation }^{1} \\
\text { Fencing }^{\mathrm{m}} \\
\text { Silo annual cost }^{\mathrm{n}}\end{array}$ & $\begin{array}{c}\text { Ib } \\
\text { cow repl unit } \\
\text { cwt } \\
\text { kwh } \\
\$ 100 \\
\$ \\
\text { cow repl unit } \\
\$ \\
\$ 100 \\
\$ 100 \\
\$ \\
\$ \\
\$ \\
\$ \\
\text { cow repl unit } \\
\$\end{array}$ & $\begin{array}{c}30.50 \\
1.0 \\
5.00 \\
100.00 \\
3.34 \\
167.00 \\
1.0 \\
2.85 \\
0.212 \\
0.106 \\
21.20 \\
220.00 \\
20.00 \\
80.00 \\
1.0 \\
-\end{array}$ & $\begin{array}{l}\$ 0.047 \\
3.50 \\
1.30 \\
0.04 \\
0.72 \\
0.0065 \\
2.85 \\
0.01 \\
1.75 \\
1.20 \\
0.05 \\
0.015 \\
0.1667 \\
0.125 \\
5.00 \\
\quad-\end{array}$ & $\begin{array}{r}\$ 1.43 \\
3.50 \\
6.50 \\
4.00 \\
2.40 \\
1.09 \\
2.85 \\
0.03 \\
0.37 \\
0.13 \\
1.06 \\
3.30 \\
3.33 \\
10.00 \\
5.00 \\
7.15 \\
\end{array}$ & $\begin{array}{r}\$ 1.43 \\
3.50 \\
6.50 \\
4.00 \\
2.40 \\
1.09 \\
2.85 \\
0.03 \\
0.37 \\
0.13 \\
1.06 \\
3.30 \\
3.33 \\
10.00 \\
5.00 \\
3.33 \\
\end{array}$ & $\begin{array}{c}\$ 1.43 \\
3.50 \\
6.50 \\
4.00 \\
2.40 \\
1.09 \\
1.43 \\
0.02 \\
0.37 \\
0.13 \\
1.06 \\
3.30 \\
3.33 \\
10.00 \\
5.00 \\
- \\
\end{array}$ \\
\hline & & & & $\$ 52.14$ & 48.32 & 43.56 \\
\hline
\end{tabular}




\section{Appendix Table 16 Continued}

\begin{tabular}{lcc} 
& \multicolumn{2}{c}{ Hours } \\
Labor Requirements & Silage \& Combination & Hay \\
Spring & 2.20 & 2.20 \\
Summer & 0.90 & 0.90 \\
Fall & 1.50 & 1.50 \\
Winter $^{0}$ & 11.60 & 5.80 \\
\hline Total & 16.20 & 10.40
\end{tabular}

${ }^{a}$ Expenses are equal for feeding systems of silage-only and silage and hay except for a lower silo depreciation cost using the combination system. The hay-only system has a lower feeding equipment cost and less winter labor required than the two silage systems.

b Amount used taken from Ronald A. Layton, Alfred L. Barr, and Paul E. Nesselroad, Estimated Annual Costs, Production, and Income for Selected Livestock and Crop Enterprises, Eastern West Virginia, West Virginia University Agricultural Experiment Station Bulletin 594T (Morgantown: West Virginia University, 1970), Table 1.01, p. 9. Rate used was $\$ 4.70 / 100$ Ibs.-Southern States Cooperative, Morgantown, W. Va., March, 1976 (telephone).

'Amount used taken from Layton, et al., loc. cit. Dollar value used by Layton was inflated 75 percent using price indexes from USDA, Agricultural Statistics, Statistical Reporting Service, (Washington, D.C.: U.S. Government Printing Office, 1975), Table 637, p. 455.

'Layton, et al., loc. cit. Dollar value for transportation and marketing inflated 75 percent using price indexes.

'Amount taken from Layton, ot al., loc. cit. Rate was estimated using Monongahela Power Co. electricity bills of author for rural Preston County, W. Va., January, 1976

fPurchase value of a cow replacement unit was $\$ 334$. Rate was $\$ 0.72 / \$ 100$ of value.
${ }^{8}$ Tax rate was 0.65 percent of 50 percent of value.

hLayton, et al., loc. cit. Value was inflated 78 percent using price indexes. Equipment value was reduced one-half for hay-only system.

'Layton, et. al., loc. cit. Approximately 1 percent of equipment value.

'Building space requirements of $50 \mathrm{sq}$. $\mathrm{ft}$. per cow was obtained from Agricultural Planning Data for the Northeastern United States, Department of Agricultural Economics and Rural Sociology, A.E. \& R.S. 51 (University Park: The Pennsylvania State University, 1965), Table 42, p. 71. Ten percent of that requirement was used in this thesis for a limited housing system. Building space value of $\$ 2.00 / \mathrm{sq}$. ft. was obtained from Alfred $\mathrm{L}$. Barr, Beef Cattle Production: Costs and Returns for the Cow-Calf System in West Virginia, West Virginia University Agricultural Experiment Station Bulletin 527 (Morgantown: West Virginia University, 1966, reprinted 1969), Table 6, p. 20. This value was inflated to $\$ 4.24$ using price indexes. Five sq. $\mathrm{ft}$. per cow replacement unit at $\$ 4.24 \mathrm{sq}$. $\mathrm{ft}$. gives a building space value of $\$ 21.20 /$ cow replacement unit. Building insurance was calculated at $\$ 1.75 / \$ 100$ value. Building taxes were calculated at 1.2 percent $\$ 100$ assessed value (50 percent of market value). Building life was estimated to be twenty years.

kLayton, et al., loc cit. 1.5 percent of cow salvage value. Cow salvage was estimated to be $\$ 220$. 
'A bull purchase value of $\$ 850$ less $\$ 350$ salvage leaves a depreciable value of $\$ 500$. For 100 cows, four bulls are required. Bull life was estimated to six years. $\$ 2,000$ divided by $100=\$ 20.00$ per cow replacement unit divided by 6 years $=\$ 3.33$ depreciation per cow per year. A cow purchase value of $\$ 300$ per cow, less $\$ 220$ salvage, leaves a depreciable value of $\$ 80$. Cow life was estimated to be eight years. $\$ 80$ divided by $8=\$ 10.00$ depreciation per cow per year to depreciate the cost of the original herd.

${ }^{\mathrm{m}}$ Alfred L. Barr, George E. Toben, and Charles C. Wilson, Jr., Resources, Production, and Income on Eastern West Virginia Beef Cattle Farms, West Virginia University Agricultural Experiment Station Bulletin 546 (Morgantown: West Virginia University, 1967), Table 30, p. 39. \$2.40 per cow replacement unit was inflated approximately 12 percent using price indexes.
"Silage-Only System-600-ton capacity cement trench silo at a cost of $\$ 5,820.00$ with a life of 15 years has annual depreciation of approximately $\$ 390$ plus approximately $\$ 185$ annual repair allowance plus approximately $\$ 150$ annual sealing cost giving a total annual cost of approximately $\$ 715$ or $\$ 7.15$ per cow replacement unit.

Silage and Hay System-250-ton capacity cement trench silo at a cost of $\$ 2,782.50$ with a life of 15 years has annual depreciation of approximately $\$ 2,782.50$ with a life of 15 years has annual depreciation of approximately approximately $\$ 63$ annual sealing cost giving a total annual cost of approximately $\$ 332.50$ or $\$ 3.33$ per cow replacement unit.

${ }^{\circ}$ The hay-only feeding system utilizing 1,500-lb round bales was estimated to require 50 percent of the winter labor required by the silage feeding systems. 
Appendix Table 17.

T.D.N. Requirements Per 100 Beef Cow Herd by Months that Need to be Supplied by Some Type of Feed. Mature Cow Weight is 1,100 pounds ${ }^{\mathrm{a}}$

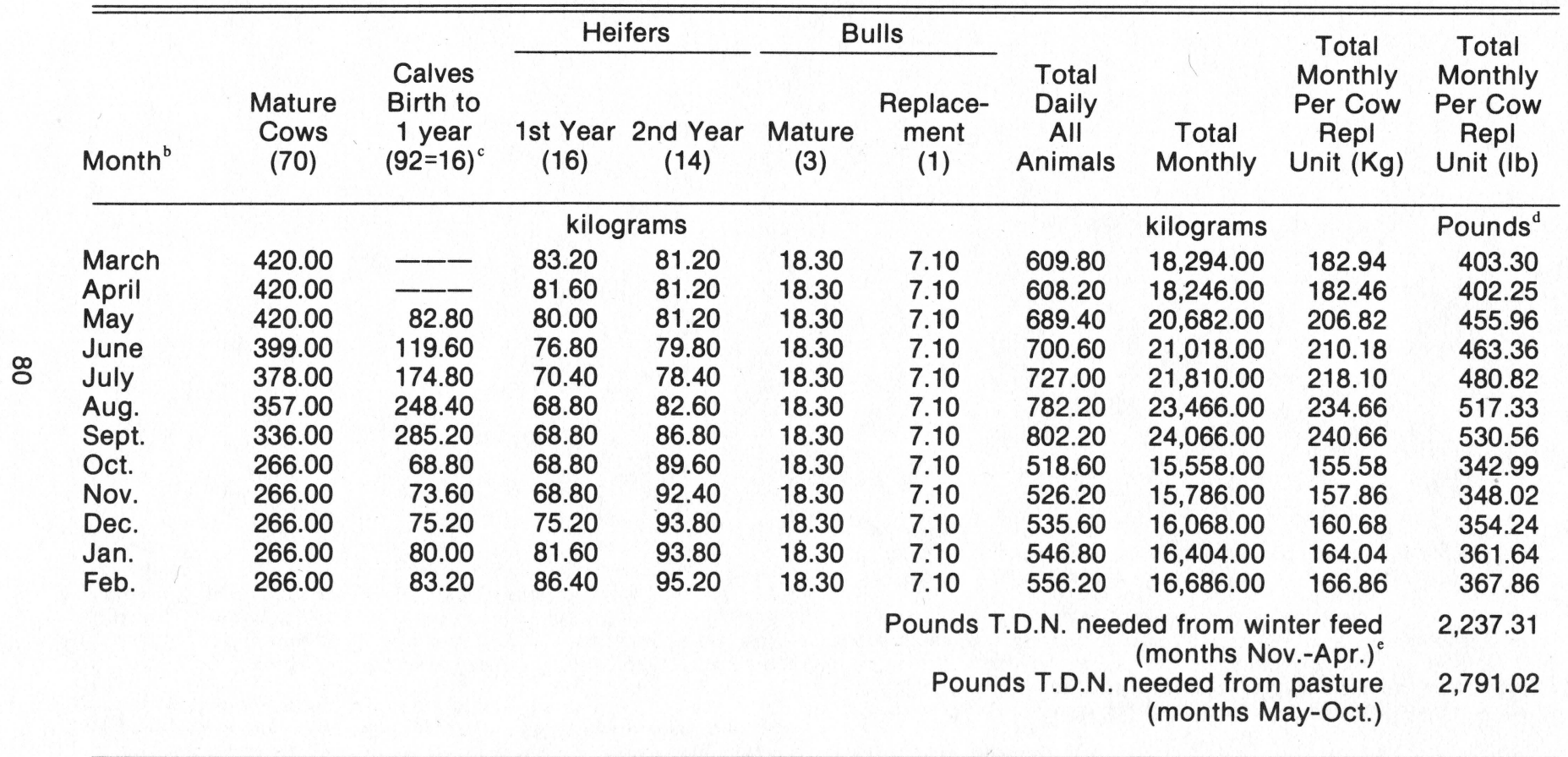


aDonald M. Hulver, "Total Digestible Nutrient Requirements for Beef Cattle During Growth, Gestation, and Lactation," (unpublished Master's thesis West Virginia University, 1976), Table 11, p. 54

${ }^{b}$ Assume cows calve on March 1st. From November through April have T.U.N. supplied by winter feed. May through October utilize pasture.

cFor the first seven months there are 92 calves, for months 8 through 12 there are 16 calves representing the number of replacement heifers kept for breeding stock.

${ }^{d} 1 \mathrm{~kg}=2.2046 \mathrm{lbs}$.
${ }^{\mathrm{e}}$ For the silage and hay feeding system, winter T.D.N. had to be divided between silage and hay on the basis of $10 \mathrm{lb}$ of hay to $20 \mathrm{lb}$ of silage (1:2). Hay is 52 percent T.D.N and silage is 23 percent T. D. . on silage (1:2). . Ib T.D.N., silage or $0.52 \times 1$ crop $+0.46 \times 1 b$ crop $=2,237.31$ Ib T.D.N. where $x$ is the variable, gives $x=2,282.97 \mathrm{lb}$ of crop (hay or silage). Therefore, $0.52 \mathrm{x}$ $=1,187.14 \mathrm{lb}$ T.D.N., $0.46 \mathrm{x}=1.050 .17 \mathrm{lb}$ T.D.N. To supply the $2,237.31 \mathrm{lb}$ T.D.N. per cow replacement unit per year and provide hay and silage in the ration of $1: 2,1,187.14 \mathrm{lb}$ T.D.N. are needed from hay and 1,050.17 lb T.D.N. are needed from silage. 


\section{Appendix Table 18.}

Crude Protein Requirements Per 100 Beef Cow Herd by Months that Need to Be Supplied by Some Type of Feed (mature cow weight is 1,100 pounds ${ }^{a}$ )

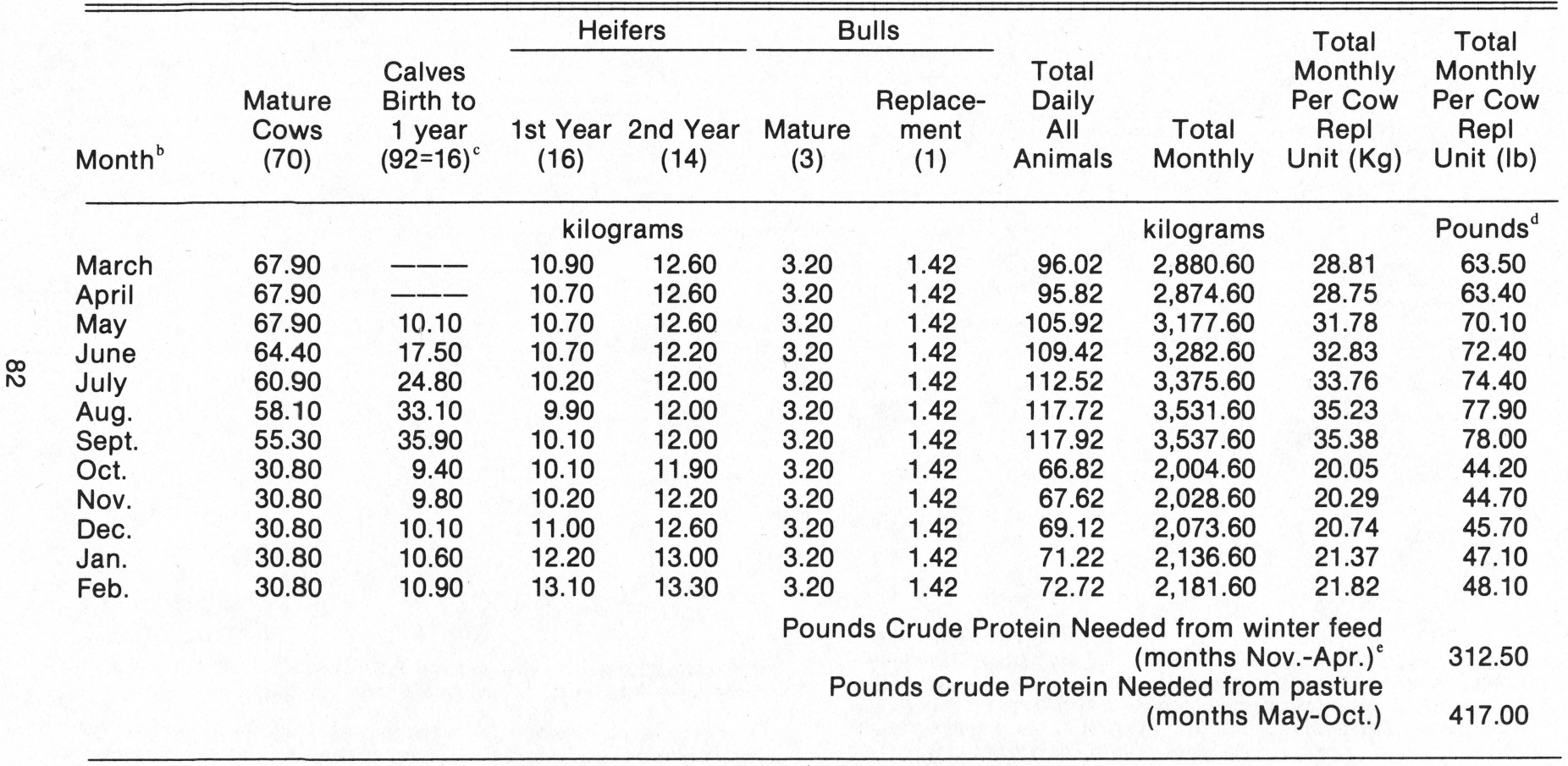


${ }^{a}$ Daily protein requirements per head were determined by Donald M. Hulver as post Master's thesis work in connection with his thesis, "Total Digestible Nutrient Requirements for Beef Cattle During Growth, Gestation, and Lactation," West Virginia University, 1976.

${ }^{b}$ Assume cows calve on March 1st. From November through April have C.P. supplied by winter feed. May through October utilize pasture.

'For the first seven months there are 92 calves, for months 8 through 12 there are 16 calves representing the number of replacement heifers kept for breeding stock.

${ }_{1} 1 \mathrm{~kg}=2.2046 \mathrm{lbs}$.
${ }^{\mathrm{e}}$ For the silage and hay feeding system, winter crude protein (C.P.) had to be divided between silage and hay on the basis of $10 \mathrm{lb}$ of hay to $20 \mathrm{lb}$ of silage (1:2). Hay is 9.38 percent (C.P.) and silage is 2.67 percent (C.P.) on an as fed basis. Therefore, $1 \mathrm{lb}$ hay to $2 \mathrm{lb}$ silage is equivalent to $0.0938 \mathrm{lb}$ (C.P.), Hay: $0.0267 \times 2 \mathrm{lb}$ C.P., silage or 0.0938:0.0534. Solving the algebraic equation of $0.0938 \times \mathrm{lb}$. crop $+0.534 \times \mathrm{lb}$ crop $=312.5 \mathrm{lb}$ C.P., where $\times$ is a variable, gives $x=3122.962 \mathrm{lb}$ of crop (hay or silage). Therefore, $0.0938 \mathrm{x}=$ $199.14 \mathrm{lb}$ C.P. and $0.0534 \mathrm{x}=113.37 \mathrm{lb}$ C.P. To supply the $312.5 \mathrm{lb}$ C.P. per cow replacement unit per year and provide hay and silage on the ratio of $1: 2,199.14 \mathrm{lb}$ C.P. are needed from hay and $113.37 \mathrm{lb}$ C.P. are needed from silage. 
Blank Page in Original Bulletin 
Blank Page in Original Bulletin 
